$$
\text { UNIVERSIDADE DE SÃO PAULO }
$$

PROGRAMA DE PÓS-GRADUAÇÃo EM CIÊNCIA AMBIENTAL - PROCAM

\title{
AS MEDIDAS JUDICIAIS APLICADAS PARA GARANTIR O DIREITO À SAÚDE: ESTUDO DE CASO EM UMA ÁREA CONTAMINADA NA CIDADE DE SÃO PAULO
}

\section{ÂNGELA APARECIDA NAPOLITANO}


PROGRAMA DE PÓS-GRADUAÇÃO EM CIÊNCIA AMBIENTAL - PROCAM

\title{
AS MEDIDAS JUDICIAIS APLICADAS PARA GARANTIR O DIREITO À SAÚDE: ESTUDO DE CASO EM UMA ÁREA CONTAMINADA NA CIDADE DE SÃO PAULO
}

\begin{abstract}
Ângela Aparecida Napolitano
Dissertação apresentada ao Programa de Pós-Graduação em Ciências Ambientais da Universidade de São Paulo, para concorrer ao título de Mestre pelo Programa de PósGraduação em Ciência Ambiental (Procam)

Orientador: Prof. Dr. Nelson da Cruz Gouveia.
\end{abstract}

São Paulo

2008 
Dedico este trabalho com todo carinho e admiração: Aos meus pais Neuza e Giuseppe, pelo que representam na minha formação intelectual e humana exemplos de amor, perseverança, trabalho, dignidade, respeito ao próximo, à vida e à natureza.

Aos meus amados irmãos Assunta, Regina, Ana Sílvia, Fernanda, Giuseppe Fernando, Ricardo Alexandre e Raquel.

Aos meus amados sobrinhos, minha querida geração futura: João Vinícius, Leonardo, Rafaella, Giovana Teresa, Ricardo Henrique, Luiza e Amanda.

Ao meu amado Domingos, que você continue sendo parte de meus sonhos, planos e conquistas.

E a todos que colaboram com o meio ambiente e se preocupam em preservá-lo para as gerações futuras. 


\section{Agradecimentos}

Ao Prof. Dr. Nelson Gouveia da Cruz pela orientação, confiança e incentivo, que possibilitaram a realização desse trabalho.

Ao Comitê de Orientação, composto pelo meu orientador, bem como pelos professores Dra. Helena Ribeiro e Dr. Pedro Roberto Jacobi, cujas sugestões colhidas, que ocasionaram reflexões e aprimoramentos.

Ao Programa de Pós-Graduação em Ciência Ambiental (Procam-USP), na pessoa de seus funcionários e professores, pelo acolhimento e aprendizado científico, durante o Curso de Pós-Graduação.

À professora Dra. Solange Teles da Silva, pelas sugestões e importantes contribuições relativas ao Direito Ambiental.

A todos os entrevistados que cooperaram para a realização desta pesquisa.

Ao Instituto Brasileiro de Pesquisas Ambientais (Ipam), na pessoa de Raquel Balogh e Sônia Coutinho, pelo apoio e incentivo para a realização deste trabalho.

Á Andréia e a todos os funcionários da $10^{\mathrm{a}}$ Vara da Fazenda Pública da Capital, pelo auxílio e contribuição para a realização da pesquisa.

Aos meus queridos cunhados amigos Camilo, Márcio, Marli, Marcelo, Fábio e Kleber, pela compreensão e incentivo durante todo esse tempo.

À minha querida Bianca, pela lealdade, compreensão e companhia amiga nas noites e madrugadas de estudo. 


\section{Resumo}

Este trabalho visa a analisar as medidas judiciais adotadas para enfrentar os riscos e agravos à saúde decorrentes da exposição a substâncias perigosas em áreas contaminadas no município de São Paulo, tendo em vista que no Brasil não há uma política específica para ser aplicada no caso em questão. São abordadas as formas de enfrentamento do problema, com ênfase na Ação Civil Pública (ACP). O caso da área contaminada da Vila Carioca foi escolhido para ser objeto de estudo por se tratar de problema atual e de conseqüências sociais diversas, além de figurar entre um dos mais graves problemas ambientais da cidade.

O trabalho versa sobre a experiência, na área jurídica, de órgãos públicos com atribuições para proteção da saúde humana, entre eles: Centro de Vigilância Sanitária, Ministério Público e Cetesb. A importância e a efetividade das medidas judiciais para a garantia do direito à saúde, a preservação do meio ambiente e o bem-estar da população, particularmente no tocante às áreas contaminadas na cidade de São Paulo, também são discutidas.

O Capítulo I discute o desenvolvimento econômico e suas implicações com o direito à saúde e o direito ambiental, à luz da Constituição Federal.

O Capítulo II trata da proteção ambiental e dos riscos ambientais do espaço urbano e sua relação com as políticas para o desenvolvimento das cidades, além de apresentar um breve histórico da regulação de risco e das atividades produtivas poluidoras.

O Capítulo III aborda alguns meios processuais coletivos de proteção e de implementação dos direitos fundamentais, com enfoque maior na ACP.

O Capítulo IV aborda um estudo de caso relacionado com a contaminação de solo no bairro da Vila Carioca, região sul da cidade.

Conclui-se discutindo os entraves jurídicos e a falta de controle do Poder Público no que se refere à defesa dos direitos coletivos em face do estudo de caso em questão.

Palavras-chave: medidas judiciais, áreas contaminadas, riscos à saúde. 


\begin{abstract}
The aim of the present work is to analyze the judicial orders adopted to tackle health risks resulting from exposure to hazardous substances in contaminated areas of the city of São Paulo, since there is no specific Brazilian policy to rule this issue. Ways of tackling the problem are discussed, with emphasis on the Civil Public Action (ACP). The case of Vila Carioca was chosen not only for being a current problem with several social consequences, but also for being one of the major environmental problems affecting the city of São Paulo in recent years.

This study focuses on the juridical experience of public institutions responsible for community health, such as: the Sanitary Surveillance Center (Centro de Vigilância Sanitária), Department of Justice (Ministério Público) and the Technology and Environmental Sanitation Company (Cetesb). In addition, it shows the importance and effectiveness of judicial orders to guarantee the right to health, protection of the environment and public welfare, especially regarding the contaminated areas in the city of São Paulo.

Chapter I discusses the economic development and its implications as to the right to health and the environmental laws, examined through the lens of the Brazilian Federal Constitution.

Chapter II discusses environmental protection and hazards in urban areas and the policies which rule the development of cities. In addition, it gives a brief account of risk regulations with reference to polluting production activities.

Chapter III discusses some collective legal procedures for protection and implementation of fundamental rights, focusing mainly on the ACP.

Chapter IV discusses a case study of soil contamination in Vila Carioca, located in the south of São Paulo.

Finally, the study discusses the legal obstacles and failures of the Public Authority in defending the collective rights concerning the case examined.
\end{abstract}

Key words: judicial orders, contaminated areas, health risks 


\section{Sumário}

Lista de Siglas...........................................................................................................

Introdução

Capítulo I - Relação entre Direito ao Meio Ambiente e Direito à Saúde....................................13

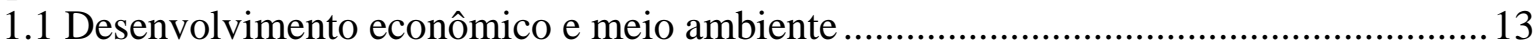

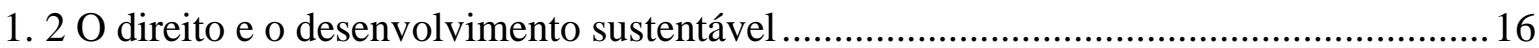

1.2.1. Questões ambientais relacionadas ao desenvolvimento sustentável ........................17

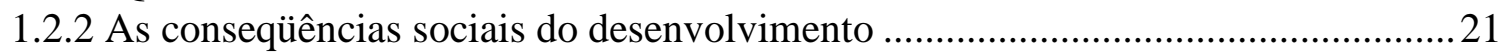

1.2.3 Saúde pública e justiça ambiental..........................................................................2

1.3 A saúde e o meio ambiente na Constituição Federal ..........................................................27

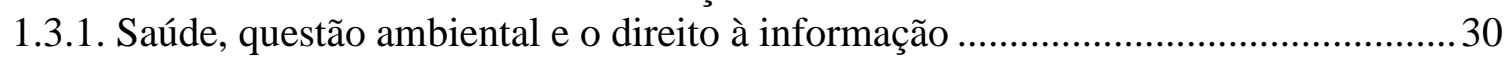

Capítulo II - Proteção Ambiental: Políticas Públicas, Instrumentos de Proteção, Legislação e

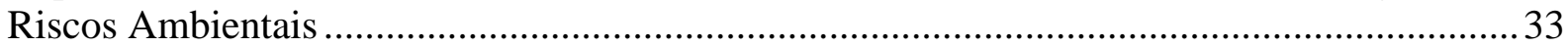

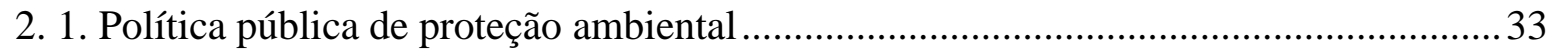

2.1.1 Dispositivos legais de proteção ao meio ambiente.....................................................36

2.1.1 a) Tutela Civil - aspectos da responsabilidade civil ambiental.........................38

2.1.1 b) Tutela Administrativa............................................................................... 40

$2.1 .1 \mathrm{c})$ Tutela Penal ........................................................................................ 42

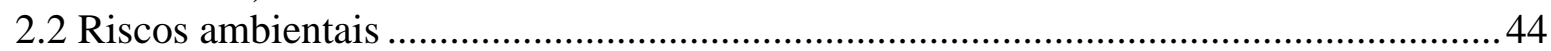

2. 3. A regulação de risco e das atividades produtivas poluidoras ........................................... 45

Capítulo III - Medidas Judiciais Aplicáveis para Garantir o direito à Saúde .............................53

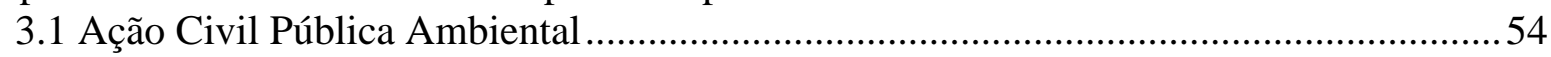

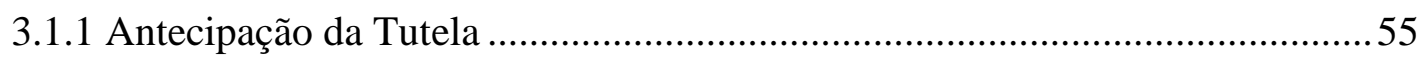

3.1.2 Medida Liminar ........................................................................................

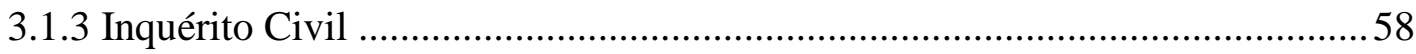

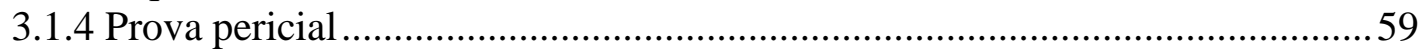

3.1.5 Termo de Compromisso de Ajustamento de Conduta (TAC) ...........................61

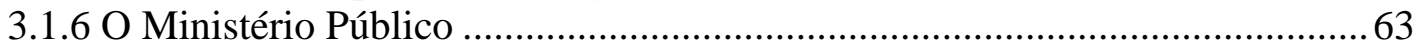

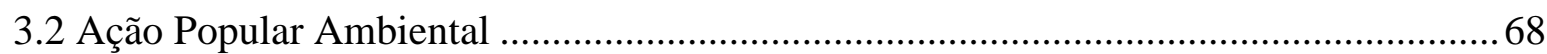

3.3 Mandado de Segurança Coletivo Ambiental ..............................................................69

3.4. Mandado de injunção em matéria ambiental ............................................................... 71

3.5 Ação Direta de Inconstitucionalidade (Adin) de Lei ou Ato Normativo em matéria

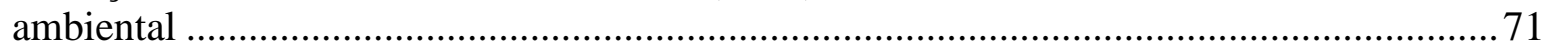

3.6. Ação Declaratória de Constitucionalidade (Adecon ou ADC).......................................72

Capítulo IV - Estudo de Caso: Ação Civil Pública Proposta para a Apuração de

Responsabilidades e Contaminação do Solo na Vila Carioca …………………………………...73

4.1 Consideraç̃̃es, metodologia e análise sobre o objeto de estudo ………………………...73

4.2. Evolução histórica da região da Vila Carioca e fatos relativos à contaminação ............77

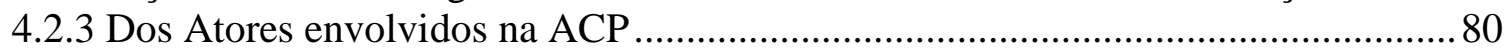

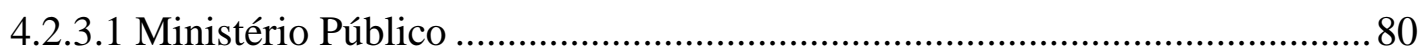

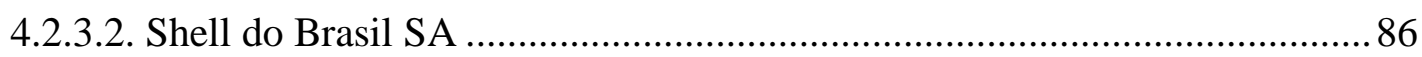

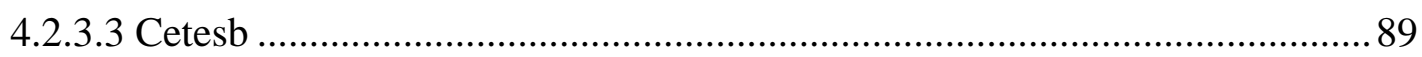

4.2.3.4 Centro de Vigilância Sanitária (CVS) .......................................................... 93

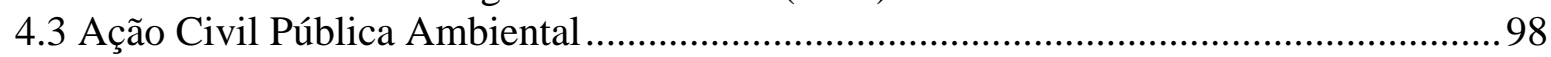

4.3.1 Dos fatos e direito que fundamentam a ACP .......................................................98

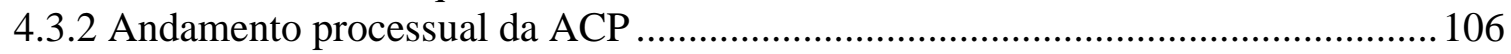

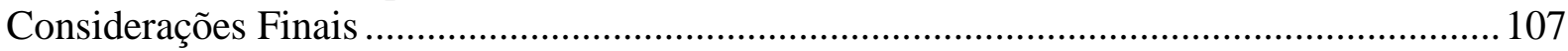

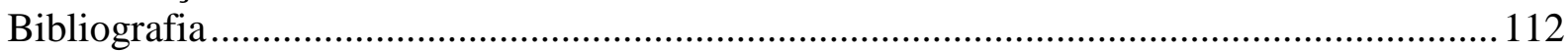

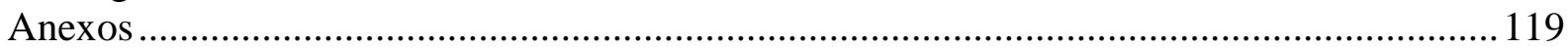




\section{Lista de Siglas}

AC - área contaminada

Adecon ou ADC - Ação Declaratória de Constitucionalidade

Adin - Ação Direta de Inconstitucionalidade

ACP - Ação Civil Pública

AIA - Avaliação de Impacto Ambiental

CDC - Código de Defesa do Consumidor

CVS - Centro de Vigilância Sanitária

Cetesb - Companhia de Tecnologia de Saneamento Ambiental do Estado de São Paulo

CF - Constituição Federal de 1988

CICPAA - Comissão Intermunicipal de Controle da Poluição das Águas e do Ar

Conamp - Associação Nacional dos Membros do Ministério Público

Consema - Conselho Estadual de Meio Ambiente

Feprac - Fundo Estadual para Prevenção e Remediação de Áreas Contaminadas

IC - Inquérito Civil

IPT - Instituto de Pesquisas Tecnológicas do Estado de São Paulo

LACP - Lei da Ação Civil Pública

OMS - Organização Mundial da Saúde

ONG - organização não-governamental

ONU - Organização das Nações Unidas

PJMA - Promotoria de Justiça do Meio Ambiente

PNMA - Política Nacional de Meio Ambiente

Pnud - Programa das Nações Unidas para o Desenvolvimento

PQA - Padrão de Qualidade Ambiental

Rima - Relatório de Impacto Ambiental

Sisnama - Sistema Nacional do Meio Ambiente

STF - Supremo Tribunal Federal

SUS - Sistema Único de Saúde

TAC - Termo de Compromisso de Ajustamento de Conduta

ZEI - Zona Estritamente Industrial

ZUD - Zona de Uso Diversificado

Zupi - Zona de Uso Predominantemente Industrial 


\section{Introdução}

O ponto de partida do presente estudo foi a necessidade de entender a morosidade para finalizar uma apuração de fatos que envolvem um dano ambiental, uma vez que tal lentidão não somente agrava as conseqüências de certos fatos como também pode tornar irreversíveis as reparações dos prejuízos ambientais ou dos agravos causados à saúde humana decorrentes desses prejuízos.

Assim, em função da minha experiência pessoal como advogada especialista em direito ambiental, buscou-se fazer um vínculo entre a área de direito, o campo da saúde pública e o meio ambiente, tendo em vista que estes últimos são bastante prejudicados pelas atividades industriais, pela falta de fiscalização e controle dessas atividades, pela degradação do espaço urbano, entre muitos outros fatores.

Nesse sentido, este trabalho visa a estudar e analisar as medidas judiciais adotadas especificamente para enfrentar os riscos e agravos à saúde decorrentes da exposição a substâncias perigosas em áreas contaminadas no município de São Paulo. Considerando-se o fato de que não há uma política específica para ser aplicada ao caso em questão, serão, abordadas as formas de enfrentamento do problema e a busca de alternativas, com ênfase no aprimoramento de mecanismos legais e instrumentais utilizados pela sociedade e pelo poder público.

Cumpre salientar que a escolha de áreas contaminadas para objeto de estudo deu-se por se tratar de problema atual e de conseqüências sociais diversas, além de figurar como um dos mais graves problemas ambientais da cidade. Ademais, as áreas contaminadas se destacam também pelo interesse e integração dos poderes públicos nas esferas municipal, estadual e federal, pelo envolvimento de organizações não-governamentais (ONGs) e da coletividade, todos buscando garantir o direito à saúde da população. Por fim, há a preocupação de estabelecer diretrizes socioambientais para estas áreas, como se pretende enfocar no estudo.

Em última instância, o objetivo é verificar a efetividade das medidas judiciais tanto para assegurar o direito à saúde como a preservar o meio ambiente e para garantir o bem-estar da população, particularmente no tocante às áreas contaminadas na cidade de São Paulo. Para tanto, o estudo tem dois objetivos específicos: analisar a experiência na área jurídica de órgãos públicos com atribuições no campo da proteção da saúde humana (entre eles, Centro 
de Vigilância Sanitária - CVS, Ministério Público e Companhia de Tecnologia de Saneamento Ambiental do Estado de São Paulo - Cetesb) e avaliar os problemas e os entraves técnicos que dificultam a solução satisfatória e célere da questão judicial.

O presente trabalho tem como hipótese a conjectura de sinais de colapso de um modelo de cidadania tutelada, a qual tem como base a noção de acesso à Justiça e a própria juridicidade na tradição brasileira. Nesse sentido, tanto o aparelho estatal apresenta sinais de obsolescência como a sociedade civil dá indicações de falta de familiaridade com uma militância cívica, gerando demora para a solução de problemas e, por consequiência, a possibilidade de perda da garantia de direitos e do meio ambiente ecologicamente equilibrado.

O método utilizado para confirmar a hipótese será a análise concreta da Ação Civil Pública (ACP) Ambiental proposta pelo Ministério Público do Estado de São Paulo contra a Shell Brasil SA e a Companhia de Tecnologia de Saneamento Ambiental (Cetesb).

A pesquisa foi realizada utilizando-se os dados obtidos nos autos da Ação em questão e informações fornecidas pelo representante do Ministério Público Estadual da $2^{\mathrm{a}}$ Promotoria de Justiça do Meio Ambiente (PJMA) da Capital, responsável por promover a tutela judicial relativa ao meio ambiente no Estado de São Paulo. Os procedimentos realizados foram: levantamento e acompanhamento da ACP Ambiental em andamento; leitura do inquérito civil que deu origem à ACP e também entrevistas com o representante do Ministério Público Estadual, responsável pela tutela ambiental, bem como de outros atores envolvidos com o problema ambiental.

O Capítulo I apresenta um pano de fundo conceitual envolvendo o desenvolvimento econômico e suas implicações com o direito à saúde e o direito ambiental, à luz da Constituição Federal.

Já o Capítulo II trata da proteção ambiental e dos riscos ambientais do espaço urbano e sua relação com as políticas para o desenvolvimento das cidades, além de desenvolver um breve histórico da regulação de risco e das atividades produtivas poluidoras.

Por sua vez, o Capítulo III aborda alguns meios processuais coletivos de proteção e de implementação dos direitos fundamentais, sendo que o enfoque maior será a ACP; discute ainda as legislações e os entraves jurídicos encontrados diante da necessidade de garantir o direito à saúde e à qualidade de vida.

Expostos esses aspectos de caráter teórico, o Capítulo IV descreve e contextualiza os procedimentos realizados, abordando um estudo de caso relacionado com a contaminação de solo no bairro da Vila Carioca, região sul da cidade. Trata-se de um problema de contaminação que gerou e ainda gera vários problemas e agravos de saúde, sendo que a ACP 
encontra-se em andamento, possui mais 3.500 páginas (18 volumes) e foi proposta pelo Ministério Público do Estado de São Paulo em 26 de março de 2002 contra a Shell Brasil SA e a Cetesb, como já mencionado.

Por fim, o trabalho conclui discutindo a falta de uniformidade de critérios para monitoramento da saúde pública entre os diversos órgãos responsáveis para fiscalização das atividades poluidoras. De igual modo, registra a constatação de áreas contaminadas, bem como a ineficácia do controle do Poder Judiciário no que se refere à garantia do direito à saúde em face dos entraves jurídicos e dos interesses econômicos. 


\title{
Capítulo I - Relação entre Direito ao Meio Ambiente e Direito à Saúde
}

\begin{abstract}
A idéia de desenvolvimento está no centro da visão de mundo que prevalece em nossa época. Nela se fundamenta o processo de invenção cultural que permite ver o homem como um agente transformador do mundo.
\end{abstract}

Celso Furtado

\subsection{Desenvolvimento econômico e meio ambiente}

É sabido que, historicamente, o desenvolvimento de muitos países se deu à custa de grandes perdas ambientais. A industrialização e o conseqüente processo de urbanização criaram impactos sobre a natureza - seja pela utilização acelerada de recursos naturais nos processos produtivos, seja pela geração de matérias poluidoras despejadas na própria natureza que degradam a qualidade ambiental e a saúde humana.

Segundo Cristiane Derani (2001, p. 61), o direito econômico é a normatização da política econômica como meio de dirigir, implementar, organizar e coordenar práticas econômicas, tendo em vista uma finalidade ou várias e procurando compatibilizar fins conflituosos dentro de uma orientação macroeconômica. Assim, num primeiro plano estaria o funcionamento do todo e não a regulamentação do comportamento individual isolado. Neste sentido, é o direito um instrumento utilizado pela política econômica, sendo esta também orientada pelo direito econômico, o qual se revela como seu fundamento, o ponto de partida para o seu desenvolvimento.

No que diz respeito ao conceito de desenvolvimento econômico, ele surgiu após a Segunda Guerra Mundial, fundado em uma teoria econômica que depositava na ação regulatória do Estado a possibilidade de manutenção de taxas de crescimento elevadas. Mediante o entendimento de tal conceito, de um lado estabelecia-se a utilização cada vez maior dos recursos naturais e de outro se desconsideravam a conseqüente degradação ambiental decorrente da atividade econômica. Assim, não se estabeleciam limites para a utilização de matérias-primas e energia e muito menos se levava em conta o problema da poluição das águas, do ar e do solo. 
A teoria econômica que tinha por base a ideologia desenvolvimentista surgiu na década de 1930 em decorrência do desemprego decorrente da crise e diante da necessidade de empregar mão-de-obra e aplicar capital a níveis máximos. Por efeito dessas circunstâncias, o aquecimento da economia fez que aumentasse a utilização dos insumos (recursos naturais e energia) que, por serem abundantes e baratos, eram utilizados sem limites. Nota-se, a propósito, que os custos sociais da utilização dos recursos naturais e da geração de efluentes sólidos, líquidos e gasosos ficaram à margem da economia, não internalizados ou contabilizados no preço.

Nas décadas de 1970 e de 1980, as questões ambientais deixaram de ser uma preocupação apenas das ciências naturais: ultrapassaram suas fronteiras e se integraram ao dia-a-dia de políticos, economistas, sociólogos, profissionais do direito (advogados, promotores e juízes) e da saúde pública, entre outros ramos das atividades humanas.

Edis Milaré, a esse respeito, dizia em 1988 que "A problemática ecológica está na ordem do dia. Basta atentar para as fontes de informação para se ver que as agressões ambientais diuturnamente desfilam nos noticiários" (1988, p. 17). Evidencia-se que tal discurso, embora feito há 20 anos, é cada vez mais atual.

Antes de analisar as políticas econômicas é importante definir políticas públicas que constituem instrumentos de ação governamental. Como destaca Maria Paula Dallari Bucci, “são programas de ação governamental visando a coordenar os meios à disposição do Estado e as atividades privadas, para a realização de objetivos socialmente relevantes e politicamente determinados" (2002, p. 241).

No caso do direito econômico, ele pode ser compreendido tanto como instrumento de política econômica quanto como um direito político - quando procura realizar a ordem econômica visando à implementação dos objetivos de uma sociedade e a uma efetiva justiça.

A política econômica, então, trabalha necessariamente com a coordenação da atividade de mercado, com a concorrência, com a prestação de serviços do Estado. Mas essa política precisa ser mais abrangente, ou seja, deve tratar de questões ambientais, tais como: reaproveitamento de resíduos, reúso de água, exigências de equipamento industrial ou novas tecnologias para produção limpa, aproveitamento de recursos naturais (outorga de recursos hídricos), entre outras questões limítrofes da economia com a ecologia.

Por sua vez, Cristiane Derani (2001) esclarece que são indissociáveis os fundamentos econômicos de uma política ambiental conseqüente e exeqüível. Explica que uma estratégia econômica conseqüente não ignora a necessidade de uma política de proteção dos recursos naturais. Para isto, a economia deveria voltar aos seus pressupostos sociais e abandonar 
qualquer pretensão por ser uma ciência exata, observando que o que está em jogo não é só a otimização do uso privado de recursos, mas as "externalidades" decorrentes e o modo de como esses recursos são apropriados.

Para a autora, a economia política deve distender-se para uma política econômica que, na verdade, deve ser denominada de modo mais abrangente como política social. Por meio de uma política econômica pode-se empreender macroplanejamentos que coordenem interesses privados e coletivos, evitando que a realização de um seja a negação do outro, reinserindo na produção a finalidade de constituição de riqueza social, voltando-se à melhoria da vida em sociedade.

Dessa forma, tem estado cada vez mais evidente a relação entre economia e meio ambiente. Todavia, essa relação também se manifesta de modo negativo. Na verdade, existe outro aspecto que é importante salientar: trata-se do problema da deterioração ambiental que, obviamente, incide nas economias dos países em variados graus, lembrando, porém que o meio ambiente ainda está sendo visto como mantenedor dos sistemas essenciais de suporte da vida, sem os quais esta não pode permanecer ou existir.

Se o meio ambiente mantém os sistemas que suportam a vida, a crescente escassez de determinados recursos naturais e a deterioração desse mesmo ambiente não podem ser omitidas dos cálculos econômicos sem que tal omissão cause dano à realidade e à relevância da análise econômica para muitos países, especialmente para as economias que dependem de recursos naturais. $\mathrm{Na}$ verdade, o ar e a água poluídos infligem, de forma nítida, danos à sociedade - danos que se traduzem em prejuízos à saúde e em perda econômica visível. A ciência, nesse ponto, tem ajudado a identificar as fontes da poluição, tornando-se mais eficiente o seu controle. Então, os custos externos das atividades econômicas agora estão sendo progressivamente internalizados e uma combinação de penalidades e de incentivos e prêmios, bem como de regulamentação, está sendo levada a cabo em um número crescente de países, num esforço para conter o avanço da poluição.

Para Solange Teles da Silva (21/12/2007), as políticas públicas devem ser concebidas não mais no sentido de intervenção sobre a atividade privada, mas de diretriz geral para a ação tanto dos indivíduos e organizações como do próprio Estado. Nesse sentido, os princípios têm um papel essencial para a implementação do direito de políticas públicas, sobretudo em matéria de proteção ambiental e ordenamento do território.

De acordo com Silva, o interesse na utilização dos princípios diretores às regras fixas explica-se porque "eles são os únicos capazes de assegurar a compatibilidade de valores e interesses complementares ou contraditórios que buscam a otimização da vida", possibilitando 
a coexistência de legislações que protejam valores e interesses diversos. Dentre os princípios que orientam as políticas públicas no meio ambiente urbano destacam-se: o princípio da supremacia do interesse público na proteção do meio ambiente urbano sobre os interesses privados; o princípio da intervenção estatal obrigatória na defesa e proteção do meio ambiente urbano; o princípio da avaliação prévia dos impactos ambientais de atividades de qualquer natureza; o princípio da função socioambiental da propriedade urbana; o princípio da participação popular e da gestão democrática da cidade; e o princípio da garantia do direito a cidades sustentáveis.

A autora sustenta que a adoção de políticas públicas buscando a sustentabilidade urbana implica repensar o modelo de desenvolvimento, repensar a evolução das relações sociais e econômicas na cidade e o papel do direito como propulsor do direito à cidade sustentável. Ou seja, trata-se de gestão sustentável do espaço urbano, tendo em vista estratégias de inclusão social, eqüidade no acesso aos recursos ambientais e a realização da justiça ambiental.

Assim, com relação ao desenvolvimento econômico e ao meio ambiente, verifica-se que o Estado não deve inserir a proteção ambiental dissociada da política econômica, pois os seus efeitos concretos atingem diversas esferas da sociedade.

\section{20 direito e o desenvolvimento sustentável}

A proteção do meio ambiente torna-se cada vez mais necessária, dentro da ordem internacional e constitucional, preocupação global justificada pelos riscos e degradações ambientais. Desta forma, atualmente se está buscando conciliar desenvolvimentismo e meio ambiente, na tentativa de chegar mais próximo de um desenvolvimento sustentável.

Segundo a Comissão Mundial sobre Meio Ambiente e Desenvolvimento, define-se desenvolvimento sustentável como aquele que atente às necessidades do presente sem comprometer a possibilidade de as gerações futuras atenderem às suas próprias necessidades (1991, p. 46).

Por sua vez, José Eli da Veiga (2005), que analisa a compatibilidade entre desenvolvimento humano, crescimento econômico e possibilidade de um desenvolvimento ambientalmente sustentável, argumenta que só há desenvolvimento quando os benefícios do crescimento servem à ampliação das capacidades humanas, entendidas como o conjunto das coisas que as pessoas podem ser ou fazer na vida. E, de acordo com ele, são quatro as mais elementares: ter uma vida longa e saudável, ser instruído, ter acesso aos recursos necessários a 
um nível de vida digno e ser capaz de participar da vida da comunidade. As pessoas, diz ele, são as verdadeiras riquezas das nações. Na verdade, o objetivo básico do desenvolvimento é alargar as liberdades humanas. O processo de desenvolvimento pode expandir as capacidades humanas, ampliando as escolhas que as pessoas têm para ter vidas plenas e criativas.

O autor, em artigo eletrônico publicado em junho de 2005 na revista Ciência e Cultura, afirma que o desenvolvimento sustentável é um dos mais generosos ideais surgidos no século passado, só comparável ao (bem mais antigo) anseio por justiça social; e conclui que se trata de uma utopia para o século XXI, pois, quando se tem uma taxa alta de crescimento econômico, em contrapartida, têm-se conseqüências irreversíveis e catastróficas para o ambiente natural e a humanidade, as quais,"Não destruiria[m] a Terra, nem a tornaria[m] inabitável, mas certamente mudaria[m] o padrão de vida na biosfera, e poderia[m] muito bem torná-la inabitável para a espécie humana" (9/12/2007).

Assim, destaca que as sociedades industriais estão entrando em uma nova fase de sua evolução, na qual urge possibilitar o desenvolvimento sustentável. E compara: essa transição será tão significativa quanto aquela que tirou as sociedades européias da ordem social agrária e levou-as à ordem social industrial.

Neste contexto, verifica-se que é complexo colocar em prática desenvolvimento sustentável, porém todo o mundo sente a urgência de se tornar sustentável o futuro, pois facilmente se percebe o problema no ar ou no sabor da água, no aumento de problemas de saúde por poluição, na mortandade de peixes, na destruição das florestas, no aumento de passivo ambiental e no aquecimento global.

Discutem-se nos tópicos seguintes as questões ambientais relacionadas com o desenvolvimento sustentável, tendo em vista a influência do direito em regulamentar a economia e o comportamento dos cidadãos, objetivando a preservação do meio ambiente ecologicamente equilibrado.

\subsubsection{Questões ambientais relacionadas ao desenvolvimento sustentável}

Cada vez mais a questão ambiental se revela como uma área de interesse do direito, em função da qual são criados instrumentos legais e instituídos órgãos de atuação, e pela intervenção na esfera econômica e no controle e fiscalização das atividades econômicas que geram resíduos ou efluentes de inúmeras espécies. Assim é que se pode verificar que a lei regulamenta a economia e o comportamento dos cidadãos na exploração e utilização de recursos escassos. No que tange à problemática ambiental, o inciso VI do artigo 170 da nossa 
Constituição dispõe que, entre diversos princípios, a ordem econômica deve observar a defesa do meio ambiente. Trata-se do Princípio do Desenvolvimento Sustentável, que procura compatibilizar desenvolvimento econômico-social e preservação da qualidade do meio ambiente.

Assim, para alcançar o desenvolvimento sustentável, determina a lei máxima do país que a proteção do meio ambiente deve ser parte integrante do processo de desenvolvimento e não pode ser considerada isoladamente em relação a ele.

A Constituição Federal de 1988, no artigo 225, inciso V, prevê que o poder público, para assegurar o direito a um meio ambiente equilibrado ecologicamente, deverá "controlar a produção, a comercialização e o emprego de técnicas, métodos e substâncias que comportem risco para a vida, a qualidade de vida e o meio ambiente".

$\mathrm{O}$ art. $4^{\circ}$ da Lei $\mathrm{n}^{\circ}$ 6.938/81, que institui a Política Nacional do Meio Ambiente, prevê que tal política visará à compatibilização do desenvolvimento econômico-social com a preservação da qualidade do meio ambiente e do equilíbrio ecológico.

Para Eros Grau (1991, p. 234), a questão ambiental colocada no patamar constitucional significou um grande avanço, uma vigorosa resposta às correntes que propõem a exploração predatória dos recursos naturais, defendida sob o argumento absurdo segundo o qual as preocupações com a defesa do meio-ambiente envolvem proposta de retorno à barbárie.

Cristiane Derani explica que as normas ambientais são essencialmente voltadas à relação social e não a uma "assistência" à natureza, ou seja, "O direito ambiental é um direito para o homem. É um direito que deve ver o homem em todas as dimensões de sua humanidade" (2001, pp. 79-80). Por isto, todo estudo que pretenda analisar a relação entre processos econômicos, ambientais e jurídicos não pode valer-se de teorias abstratas e descompromissadas. $\mathrm{O}$ valor real da teoria está em sua realização, a partir do seu contato com a realidade. Por isto, deve desenvolver-se dentro de dimensões reais (sociais), formando-se num todo de tempo e espaço.

O Direito Ambiental tem como cerne o direito de todos os brasileiros ao meio ambiente ecologicamente equilibrado, passível de fruição por toda coletividade, "bem de uso comum do povo", como reza o art. 225, caput da Constituição do País. É com base neste direito fundamental que se desdobram as demais normas pertencentes ao ramo do direito ambiental.

A Constituição Federal, nesse particular, é marcada por um caráter integrador da ordem econômica com a ordem ambiental, unidas pela finalidade comum de melhoria da 
qualidade de vida. $\mathrm{O}$ direito de todos a um meio ambiente ecologicamente equilibrado pode ser caracterizado como um direito fundamental, gozando do mesmo status daqueles descritos no art. $5^{\circ}$ da Carta Magna. Nesse contexto, o meio ambiente ecologicamente equilibrado é um pressuposto para a concretização da boa qualidade de vida.

Cumpre salientar ainda que leis e regulamentações são instrumentos extremamente importantes para transformar em ações as políticas do binômio meio ambiente e desenvolvimento. E isso ocorre não apenas por meio de métodos do tipo "ordem e acompanhamento", mas também enquanto estrutura regulamentadora para o planejamento econômico e para os instrumentos do mercado. Aliás, o objetivo geral de aperfeiçoamento da legislação é promover a integração entre as políticas de meio ambiente e desenvolvimento por meio da formulação de leis, regulamentos, instrumentos e adequados mecanismos coercitivos em nível nacional, estadual e local.

Nessa perspectiva, é preciso que se promulguem leis, regulamentos e normas aplicáveis e eficazes, apoiados em princípios econômicos, sociais e ambientais; e embasados, de igual modo, em uma avaliação adequada dos riscos, incorporando as sanções destinadas a punir violações, obter compensações e impedir violações futuras.

Se de um lado, porém, verifica-se que as leis e as regulamentações ambientais são importantes, de outro, elas não podem, por si sós, pretender resolver todos os problemas relativos ao meio ambiente e ao desenvolvimento. Preços, mercados, políticas fiscais e econômicas também desempenham um papel complementar na determinação de atitudes e comportamentos no que diz respeito à proteção ambiental e à proteção dos recursos naturais.

Neste sentido, durante os últimos anos, tanto nos países industrializados como nos países em desenvolvimento, vem se intensificando a prática de abordagens econômicas, inclusive as voltadas para o mercado, implantadas segundo alguns princípios já consagrados, como o do "poluidor-pagador", e conceitos mais recentes, como o do "usuário-pagador". Entendem-se tais noções como um recurso econômico utilizado para que o degradador arque com os custos da atividade poluidora, ou seja, para que haja a internalização das externalidades. Por esse princípio busca-se consagrar a idéia de que aquele que poluir terá de arcar com os custos da reparação do dano causado. Assim, não se pode entender que o pagamento pecuniário e a indenização tornem legítima a atividade lesiva, ao contrário, visa a desestimular condutas danosas ao meio ambiente.

Nesse sentido, bem destaca Edis Milaré que o princípio não objetiva tolerar a poluição mediante um preço, nem se limita apenas a compensar os danos causados, mas, sim, evitar o dano ao ambiente. Exemplifica dizendo que o pagamento pelo lançamento de efluentes não 
alforria condutas inconseqüentes, de modo a ensejar o descarte de resíduos fora dos padrões e das normas ambientais. E alerta que "trata-se do princípio poluidor-pagador (poluiu, paga os danos), e não pagador-poluidor (pagou, então pode poluir). Esta colocação gramatical não deixa margem a equívocos ou ambigüidades na interpretação do princípio” (2007, p. 771).

A previsão legal encontra-se na Lei 6938/81, que dispõe "à imposição, ao poluidor e ao predador, da obrigação de recuperar e/ou indenizar os danos causados e, ao usuário, da contribuição pela utilização de recursos ambientais com fins econômicos" (art. $4^{\circ}$, VII). A previsão constitucional desse princípio encontra-se no art. $225, \S 3^{\circ}$, da $\mathrm{CF}$.

Quanto ao princípio do usuário-pagador, salienta-se que este objetiva evitar que o "custo zero" dos serviços e recursos naturais acabe por conduzir o sistema de mercado à hiperexploração do meio ambiente (Musetti, 2001, p. 87). No Brasil, além do pagamento pelo uso da água, alguns projetos também já estão sendo colocados em prática. Por exemplo, em Itacaré, no sul da Bahia, um grupo de três hotéis paga meio salário mínimo a 20 proprietários de terras do entorno, para que mantenham suas áreas de floresta preservadas (cf. O Estado de S. Paulo, p. A-27, 04.06.2006).

$\mathrm{O}$ aumento da capacidade de lidar com as questões ambientais e suas relações com o desenvolvimento econômico poderá dar-se por meio da adoção do uso mais eficaz e disseminado das abordagens econômicas orientadas para o mercado, dentro de uma estrutura ampla de políticas, leis e regulamentações voltadas para as atividades econômicas, mola propulsora do progresso de um país.

Todavia, para que essa capacidade seja efetivada, é necessário incorporar os custos ambientais às decisões das indústrias e dos consumidores, e com isso inverter a tendência de tratar o meio ambiente como um "bem gratuito", com recursos naturais abundantes e espaços físicos para receber os subprodutos descartados. Lidar com essas questões implica, na verdade, repassar os custos a outros setores da sociedade, a outros países ou às gerações futuras.

A prática da utilização de instrumentos econômicos e mecanismos de mercado deverá reorientar as políticas públicas, de forma a estabelecer estratégias eficazes de abordagens econômicas, regulamentadoras e voluntárias (auto-reguladoras). Tal prática envolve eliminar subsídios que não se coadunem com os objetivos do desenvolvimento sustentável e também pressupõe a reformulação das atuais estruturas de incentivos econômicos e fiscais na direção de manter o equilíbrio do meio ambiente paralelamente com a manutenção do ritmo do desenvolvimento econômico. 
Nesse sentido, é preciso ainda que se estabeleça uma estrutura política de estímulo à criação de novos mercados consumidores conscientes de que têm que entrar na luta contra a poluição e aprender o manejo ambientalmente saudável dos recursos. Esse desafio supõe um avanço na política de preços coerente com os objetivos do desenvolvimento sustentável.

Uma consulta à Agenda $21^{1}$ dá conta de que o uso dos instrumentos econômicos e jurídicos e dos mecanismos de mercado deverá ser eficaz, especialmente nas questões relacionadas com importantes fatores que integram o meio ambiente: energia, transportes, agricultura e silvicultura, água, resíduos, saúde, turismo e serviços. São fatores que impulsionam o desenvolvimento de um país, mas que têm por base a sustentabilidade dos recursos ambientais.

Com efeito, a sustentabilidade se caracteriza pela busca da segurança da humanidade, em que a implementação das exigências sociais, culturais e econômicas se compatibiliza com a proteção do meio ambiente. Assim, a sustentabilidade acolhe as advertências dos ecologistas e os argumentos dos economistas em favor do desenvolvimento; ambos buscando o equilíbrio e respeitando a interdependência entre as necessidades humanas e as exigências ambientais, tanto para as gerações do presente quanto para as futuras gerações. Neste contexto, o papel das normas e das políticas públicas são essenciais para garantir a concretização do direito a um meio ambiente ecologicamente equilibrado.

\subsubsection{As conseqüências sociais do desenvolvimento}

O conceito de desenvolvimento sustentável deve estabelecer regras não só de como empregar os recursos naturais, mas, principalmente, em que nível se deve aproveitá-los, não permitindo que sejam utilizados apenas para fazer frente ao crescimento populacional, dando a impressão de que a economia está crescendo, porém custando a perda definitiva de riquezas do país.

Neste sentido, vários países começam a incorporar os custos da destruição dos recursos naturais em suas análises econômicas, como é o caso da França e da Noruega, e a partir daí a estabelecer um equilíbrio desejável entre o uso dos recursos naturais (matériasprimas, energia etc.) e o desenvolvimento da sociedade.

\footnotetext{
1 "Documento que se propõe a traduzir em ações o conceito de desenvolvimento sustentável, a Agenda 21 teve a contribuição de governos e organizações da sociedade civil de 179 países, num processo preparatório que durou dois anos e culminou com sua aprovação na Rio-92. É um plano de ação a ser adotado globalmente, nacionalmente e localmente para promover um novo modelo de desenvolvimento, contendo 4 seções, 40 capítulos, 115 programas e aproximadamente 2.500 ações a serem implementadas. Texto completo e informações sobre Agenda 21 em http://www.mma.gov.br/port/se/agen21" (Mousinho, 2005, p. 334).
} 
Outro grave problema que também gera custos está relacionado com o passivo ambiental. Isso porque muitas indústrias não tratam seus efluentes ou armazenam de forma incorreta os resíduos industriais. Esse comportamento antinatureza leva à contaminação do ar, das águas e do solo, bem como à perda da biodiversidade planetária.

É evidente que o processo de produção industrial descomprometido com as práticas de preservação ambiental e acrescido do rápido crescimento demográfico, tem gerado situações de risco, "como a implantação de condomínios residenciais, shopping centers e mesmo favelas em áreas de antiga disposição irregular de rejeitos industriais e a contaminação de áreas ocupadas no entorno de empreendimentos voltados à manipulação ou estocagem de substâncias tóxicas" (Valentim, 2007, p. 20).

A título de exemplo, a Cetesb, agente governamental de controle da poluição em São Paulo, por meio de um estudo, atribuiu a origem das áreas contaminadas no Estado ao desconhecimento, no passado, de procedimentos seguros para o manejo de substâncias perigosas, bem como ao desrespeito aos procedimentos conhecidos e à ocorrência de acidentes ou vazamentos durante o desenvolvimento de processos produtivos, transporte ou armazenamento de matérias-primas e produtos.

Apesar dos propósitos estabelecidos por ocasião da Conferência das Nações Unidas sobre o Meio Ambiente e o Desenvolvimento do Rio de Janeiro em 1992, que reconheceu a necessidade de integração e equilíbrio entre as questões ambientais, sociais e econômicas para a sobrevivência da vida humana no planeta e proclamou o conceito de desenvolvimento sustentável como meta a ser alcançada nos níveis local, nacional e global, a Cetesb, nos últimos anos, continua adotando procedimentos de gerenciamento das áreas contaminadas, tendo identificado em 2002, no Estado de São Paulo, a existência de 255 áreas com tais características. Esse número subiu para 727 em 2003, no ano seguinte para 1.336 e em 2006 para 1.822, pelos dados parciais até novembro daquele ano (Cetesb, 18/10/2007). Salienta-se que o número de áreas contaminadas registradas tende a aumentar com a continuidade das ações de fiscalização empreendidas pelo órgão ambiental, principalmente nos postos de combustíveis.

Os principais contaminantes encontrados nas áreas fiscalizadas foram combustíveis líquidos, solventes aromáticos, hidrocarbonetos policíclicos aromáticos (PAHs), metais e solventes halogenados. As maiores fontes emissoras eram postos de combustíveis, atividades industriais, atividades comerciais e instalações para destinação de resíduos.

É evidente que os problemas gerados pela existência de uma área contaminada podem ser vários: danos à saúde da população, comprometimento da qualidade dos recursos hídricos 
e águas subterrâneas, restrições ao uso do solo, danos ao meio ambiente e danos ao patrimônio público e particular decorrentes da desvalorização da propriedade.

Ademais, as Regiões Metropolitanas, como se fosse um "processo natural" decorrente do processo de desenvolvimento econômico e social e ocupação do espaço, tendem a apresentar um grande crescimento das áreas periféricas onde se situam muitas das atividades industriais, gerando possibilidades de empregos. Estas áreas são caracterizadas pela precariedade dos serviços de infra-estrutura urbana, como serviço de saúde, fornecimento de água, esgoto sanitário e coleta de lixo adequados. Tudo isto contribui para uma somatória de problemas ambientais, desde desmatamento de morros ou áreas de preservação permanente até contaminação de águas para consumo e subterrâneas, que resultam no agravamento do quadro de saúde e da perda da qualidade de vida.

Nota-se, ainda, que as atividades industriais possuem diferentes modos de poluição crônica e aguda, afetando a saúde dos trabalhadores, das suas famílias e das comunidades vizinhas, bem como o meio ambiente, através de seus efluentes, contaminando águas para consumo e subterrâneas, o solo (por meio da disposição de resíduos e deposição de poluentes), bem como o ar que respiramos.

Além dos efeitos resultantes da poluição crônica industrial, devem-se considerar os associados aos acidentes industriais ambientais, que têm o potencial de afetar simultaneamente os trabalhadores, as populações vizinhas e o meio ambiente. O Brasil ocupa o segundo lugar em termos de óbitos por acidentes, conforme relação de graves acidentes apresentados no artigo de Carlos Machado de Freitas e outros autores:

Em Vila Socó, Cubatão, em 1984, um incêndio em um oleoduto provocou cerca de 500 óbitos. Em Pojuca, na Bahia, em 1983, o descarrilhamento de um comboio ferroviário transportando combustíveis resultou em explosão e incêndio, provocando o óbito de 43 pessoas, além de grande número de lesionados e desabrigados. Em maio de 1992, Rio de Janeiro, um vazamento de nuvem tóxica com produtos não identificados atingiu população vizinha, causando problemas respiratórios, principalmente nas crianças. Em janeiro de 1998, São Paulo, houve um vazamento de amônia nas instalações, exigindo-se a evacuação da população vizinha e de trabalhadores de industria próxima, sendo visível a contaminação da vegetação nas redondezas até uma distância de 800 metros além da indústria. Mais recentemente temos os exemplos dos acidentes envolvendo o setor petróleo, entre eles os casos de vazamentos de óleo na Bahia de Guanabara (RJ) e Paraná, bem como a explosão da plataforma P-36, na Bacia de Campos (RJ), resultando este último em 11 óbitos (Freitas; Barcellos; Porto, 2004, pp. 258-9).

Diante de tantos casos que envolvem problemas de poluição, degradação e injustiça ambiental, deve-se destacar um, paradigmático, que despertou interesse para este trabalho 
acadêmico. Trata-se de uma contaminação ambiental por resíduos perigosos na Cidade dos Meninos, no município de Duque de Caxias (RJ). Neste local houve, em 1954, o fechamento de uma fábrica do Ministério da Saúde, ocorrendo o abandono de cerca de 700 toneladas de resíduos da produção de Hexaclorociclohexano - HCH (grau técnico) utilizado em campanhas contra a malária. Esta área é hoje habitada por cerca de 1.500 pessoas e os resíduos foram encontrados em todos os segmentos ambientais, nos habitantes e biota locais em níveis extremamente elevados, sendo que o caso se arrasta por mais de 20 anos sem solução (Oliveira et al.,1995, pp. 228-33).

\title{
1.2.3 Saúde pública e justiça ambiental
}

O incrível desenvolvimento das forças produtivas no século XX teve em contrapartida o crescimento dos problemas socioambientais e a gravidade dos riscos ambientais, de forma que atualmente convivemos com o aquecimento global, o aumento do "buraco" na camada de ozônio, a destruição da vida nos mares, a poluição das águas e o caos climático, entre outras conseqüências.

É evidente que os problemas socioambientais ocasionam efeitos para a saúde e a qualidade de vida e para as finanças públicas e privadas. Por exemplo, os impactos devido à poluição atmosférica acarretam a incidência de enfermidades e óbitos, gerando despesas efetuadas com saúde pública.

Neste contexto, segundo dados da Secretaria Municipal do Verde e do Meio Ambiente do município de São Paulo, que se vinculam à incidência destas enfermidades e até óbitos, todos associadas à poluição atmosférica, entre 2000 e 2002:

\begin{abstract}
as internações hospitalares referentes a enfermidades do tipo DPOC (asma, bronquite, enfisema) aumentaram em cerca de 40,3\% para os pacientes menores de cinco anos de idade, mantendo-se relativamente estáveis para os maiores de 60 anos. Quanto às infecções respiratórias baixas (pneumonias e broncopneumonias), a elevação no período se situa em torno de 9,1\% para os menores de cinco anos. Em valores absolutos, os números chegaram próximos a 12.000 internações/ano. No mesmo período, os procedimentos de inalação praticamente dobraram. A taxa de mortalidade (óbitos por 1.000 habitantes) por DPOC para menores de cinco anos passou da ordem de 0,9 em 2000 para 1,5 em 2002 (Prefeitura de São Paulo, 2004, p. 172).
\end{abstract}

Outra situação, porém, relacionada ao solo é influenciada pela pressão exercida em decorrência da expansão da área urbanizada e assentamentos não autorizados. Segundo os registros, a cidade de São Paulo tem cerca de 2.000 favelas e 1.241 loteamentos irregulares e 
precários, com um total de aproximado de 2,98 milhões de habitantes, sendo 1,16 milhão em favelas e 1,82 milhão nos loteamentos (Prefeitura de São Paulo, 2004, p. 172).

Abordando a questão de áreas contaminadas prejudiciais à saúde pública, Custódio (2002, p. 2.058) salientou que as atividades humanas, principalmente as econômicas perigosas, com os respectivos resíduos, lixos ou rejeitos em geral, vêm contaminando, de forma preocupante, imensas áreas locais, estaduais, regionais e nacionais, ocasionando lesão ao meio ambiente saudável, à saúde ambiental, à saúde pública e à vida. Para a autora, estas desafiantes questões de áreas contaminadas impõem, além das medidas repressivas e recuperatórias relacionadas às contaminações atuais, obrigatórias medidas preventivas. Estas, notadamente de informação ambiental, educação ambiental e conscientização pública para participação ativa tanto do poder público como da coletividade no sentido de evitar, eliminar ou reduzir os efeitos danosos da contaminação em defesa e preservação do meio ambiente saudável, da saúde ambiental, da saúde pública e da vida, no legítimo interesse de todos.

Entretanto, além dos problemas socioambientais ocasionarem efeitos à saúde e à qualidade de vida, gerando gastos para os cofres públicos, tem-se que esta problemática abre espaço para a discussão sobre a desigualdade social na exposição da população aos riscos ambientais, ou seja, à desigualdade ambiental. De maneira geral, a população de mais baixa renda estaria mais exposta aos riscos de contaminação e doenças decorrentes da localização de suas residências, próximas a lixões, esgotos a céu aberto ou um córrego poluído; entre outros desastres, como desabamentos e enchentes, poluição industrial e violência urbana.

O Movimento de Justiça Ambiental constituiu-se nos Estados Unidos, nos anos 80, originando-se de uma articulação criativa entre lutas de caráter social, territorial, ambiental e de direitos civis. Foi a partir do final dos anos 60 que se redefiniram algumas questões ambientais para embates contra as condições inadequadas de saneamento, de contaminação química de locais de moradia e trabalho e disposição indevida de lixo tóxico e perigoso. Nos anos 70, sindicatos preocupados com saúde ocupacional, grupos ambientalistas e organizações de minorias étnicas articularam-se para incluir em suas respectivas pautas questões ambientais urbanas.

O conceito de justiça ambiental propõe unir o movimento ambientalista desenvolvido nas últimas décadas com a luta contra dinâmicas discriminatórias que sobrecarregam determinados grupos populacionais de malefícios do desenvolvimento econômico e industrial.

Grande parte dos problemas de saúde pública de um país pode ser compreendida, em última instância, como problemas de injustiça ambiental, "mecanismo pelo qual sociedades desiguais, do ponto de vista econômico e social, destinam a maior carga dos danos ambientais 
do desenvolvimento às populações de baixa renda, aos grupos sociais discriminados, aos povos étnicos tradicionais, aos bairros operários, às populações marginalizadas e vulneráveis" (Porto apud Herculano; Pádua, 2004, p. 122).

No Brasil, o caso da Vila Socó, em Cubatão/SP, é um exemplo de injustiça ambiental. Foi lá que em 1984 ocorreu um vazamento de gasolina num gasoduto da Petrobrás junto a uma favela. Muitas pessoas chegaram a armazenar gasolina para revender posteriormente e a força do incêndio que se seguiu reduziu a pó muitos corpos - e por isso jamais puderam ser encontrados. A vulnerabilidade dessa população pobre revela-se de forma trágica na discussão em torno do número de vítimas, que varia de 98 (número oficial das autoridades) a mais de 500 mortes (número estimado pelo Ministério Público com ajuda de instituições da região) (Porto, 2004, p. 123).

Outro exemplo é o caso do benzeno, substância carcinogênica que pode causar leucemia a quem a ela é exposta e que está presente principalmente nas atividades industriais relacionadas à siderurgia, petroquímica e de refino do petróleo. De acordo com dados da Fundacentro (1993), havia em 1993 cerca de 74.000 trabalhadores diretos e 42.790 trabalhadores indiretos expostos, principalmente nos pólos industriais dos municípios de Camaçari (BA), Triunfo (RS), Cubatão (SP), Duque de Caxias e Volta Redonda (RJ), observando-se que, dependendo do tipo de processo industrial, populações vizinhas também podem ser afetadas.

Todavia, poucas tentativas têm sido realizadas nos últimos anos para retificar esta situação de injustiça ambiental, pois há receio de perdas econômicas e de estagnação ou declínio da produção industrial, pretextos que têm sido utilizados pelo Estado e pelas indústrias para postergar ações que são de sua responsabilidade e que visem a reduzir e eliminar a poluição química e as injustiças ambientais decorrentes destas ações ou omissões.

Carlos Machado de Freitas, Christovam Barcellos e Marcelo Firpo de Souza Porto advertem que

a contribuição da Saúde Coletiva orientada para a justiça ambiental deve estar direcionada para respostas que, com a participação dos trabalhadores e comunidades locais, envolvam ações nos níveis locais, estaduais e federal do setor saúde, suporte técnico das instituições técnico-científicas e de ONGs que tenham atuação local, nacional e internacional (Freitas; Barcellos; Porto, 2004, p. 287).

Os autores esclarecem que estas respostas devem ser estruturadas em três estratégias fundamentais para a justiça ambiental. A primeira é a adoção de um modelo de saúde coletiva 
não só de prevenção dos riscos, baseado na eliminação das ameaças antes que os danos ocorram, mas também de promoção da saúde.

A segunda estratégia é a mudança na obrigação da prova para os poluidores que causam danos, discriminam e que não dão proteção igual para negros, pessoas de baixo rendimento e outros grupos marginalizados. Para o autor, a adoção do princípio da precaução se torna fundamental, pois fornece efeito prático a filosofia preventiva, ou seja, eliminação das ameaças antes que os danos ocorram. Este princípio justifica a intervenção regulamentadora para a restrição da poluição mesmo na ausência de provas consensuais acerca dos danos ambientais já causados, além de alterar a responsabilidade da prova para o criador de riscos.

A terceira estratégia é o redirecionamento dos impactos desproporcionais através de ações e recursos que tenham como alvo os lugares e grupos sociais que arcam com os problemas ambientais e de saúde mais graves.

\subsection{A saúde e o meio ambiente na Constituição Federal}

O direito à saúde é um direito de todos, constituindo um dever do Estado sua efetivação (art. 196 da CF), ou seja, é um bem público constitucionalmente assegurado, garantido e protegido para o pleno bem-estar de todos.

A Organização Mundial da Saúde (OMS) define saúde não apenas como ausência de doença, mas como situação de perfeito bem-estar físico, mental e social. Essa definição, embora avançada para a época, atualmente é muito discutida, por não ser esclarecedora e de difícil alcance, considerada uma utopia. É impossível alcançar o perfeito bem-estar físico, mental e social.

Julio César de Sá Rocha apresenta uma definição de saúde mais próxima da nossa realidade:

A conceituação da saúde deve ser entendida como algo presente: a concretização da sadia qualidade de vida. Uma vida com dignidade. Algo a ser continuamente afirmado diante da profunda miséria por que atravessa a maioria da nossa população. Conseqüentemente, a discussão e a compreensão da saúde passa pela afirmação da cidadania plena e pela aplicabilidade dos dispositivos garantidores dos direitos sociais da Constituição Federal (Rocha, 1999, p. 43).

De fato, o seu art. $6^{\circ}$ da Carta Magna de 1988 elencou entre os direitos sociais o direito à saúde como inquestionável e inerente a todo ser humano; o art. $4^{\circ}$, inciso II, por seu turno, 
demonstra a preocupação do país em consagrar a prevalência dos direitos humanos; o art. $5^{\circ}$ dispõe sobre a inviolabilidade do direito à vida; o art.170 propugna, dentre outros, uma existência digna, bem como a garantia de defesa do meio ambiente; o art. 194 faz menção expressa ao direito à saúde quando trata da seguridade social; e o art. 196 expõe de maneira clara a obrigação do Estado de prestar os serviços de saúde de forma universal e igualitária.

Deste modo, partindo da leitura dos artigos acima mencionados, remete-se de modo direto ao art. 225, e pode-se concluir junto com Santos (2002, p. 99) sobre a importância do meio ambiente e dos mecanismos que o protejam e preservem, para que sejam fornecidos fundamentos para o estabelecimento da saúde. O mesmo autor esclarece, ainda, que só o meio ambiente não assegura a saúde, mas é indispensável, sem o qual aquela deixa de existir ou fica exposta aos riscos de agravos. Assim, observa que o legislador constituinte optou por tutelar de forma imediata a qualidade do meio ambiente e de forma mediata a saúde, o bemestar e a segurança da população, o que se vem sintetizando na expressão qualidade de vida.

Todavia, ao determinar que a saúde é um dever do Estado, a ser garantido por meio de políticas econômicas ou sociais que visem à redução dos riscos de doenças e de outros agravos à saúde (arts. 196 e 198, II), a Carta Magna determinou que compete ao Estado prever os riscos que existem na sociedade e que podem causar doenças ou agravos à saúde e adotar as medidas necessárias para evitá-los ou reduzi-los.

Dessa forma, pode-se verificar que a saúde foi tratada de maneira criteriosa pela Constituição de 1988. Em seguida, já em 1990, duas leis vieram regulamentar o disposto na Carta maior, que são a Lei $\mathrm{n}^{\circ}$ 8.080/90 e a Lei $\mathrm{n}^{\circ}$ 8.142/90, que tratam, respectivamente, das condições para a promoção, proteção e recuperação da saúde, bem como da organização e do funcionamento dos serviços correspondentes e da participação da comunidade na gestão do Sistema Único de Saúde (SUS) e das transferências intergovernamentais de recursos financeiros na área da saúde, além de outras providências.

O sistema único de saúde deve controlar e fiscalizar procedimento, produtos e substâncias de interesse para a saúde pública e participar da produção de medicamentos, equipamentos e insumos (art. 200 da CF). Deve executar ações de vigilância sanitária, epidemiológica e de saúde do trabalhador.

Fernando Aith faz uma abordagem interessante da relação entre saúde pública e poder: para o autor, a saúde pública é um exercício de poder voltado à saúde da população, à segurança sanitária, à saúde individual e assim por diante, porém alerta que sempre um exercício de poder e de força deve ser bem dosado para evitar abusos. Elucida que as atuais discussões sobre transgênicos, clonagens e experiências genéticas em seres humanos mostram 
o quanto a saúde pública é um exercício de poder e, ainda, o quanto o direito possui um papel fundamental para a eficácia das ações de saúde em geral e de saúde pública em especial. E adverte: "Não fosse assim, certamente já existiriam clones humanos sendo testados em diversos países do mundo" (2007, p. 26).

Souza utiliza o conceito de qualidade de vida formulado por Wilheim e Déak, que é o seguinte:

é a sensação de bem-estar do indivíduo. Este é proporcionado pela satisfação de condições objetivas (renda, emprego, objetos possuídos, qualidade de habitação) e de condições subjetivas (segurança, privacidade, reconhecimento, afeto).

Importante ressaltar que a Lei $\mathrm{n}^{\circ} 8.080 / 90$ praticamente repete os princípios e conceitos da OMS. A Organização Mundial de Saúde conceitua, como já mencionado: "Saúde é um estado de completo bem-estar físico, mental e social e não meramente a ausência de doença ou enfermidade". O que evidencia a simetria existente com a Lei brasileira é a unidade de desígnios entre o conceito da OMS e o art. $3^{\circ}$ da referida Lei, que determina:

Art. $3^{\circ}$ A saúde tem como fatores determinantes e condicionantes, entre outros, a alimentação, a moradia, o saneamento básico, o meio ambiente, o trabalho, a renda, a educação, o transporte, o lazer e o acesso aos bens e serviços essenciais; os níveis de saúde da população expressam a organização social e econômica do País.

Resta, assim, a evidente preocupação com a qualidade de vida do ser humano..

Portanto, deve-se reconhecer que o legislador constituinte foi extremamente eficaz ao proteger a saúde de forma mediata e o meio ambiente de forma imediata, já que este reúne em seu bojo os requisitos necessários à proteção da saúde como um todo e, conseqüentemente, o aumento da qualidade de vida. Deve-se compreender que os níveis de saúde de uma determinada população expressam de forma direta a organização social e econômica de um determinado local.

A própria Lei $\mathrm{n}^{\circ}$ 8.080/90 determina alguns princípios norteadores do direito à saúde no seu artigo $7^{\circ}$, incisos de I a XIII. No presente trabalho destacam-se os seguintes:

Princípio da Universalidade: está contido no art. 196 da Constituição Federal, que dispõe: "a saúde é direito de todos e dever do Estado, garantido mediante políticas sociais e econômicas que visem à redução do risco da doença e de outros agravos e ao acesso universal e igualitário às ações e serviços para a sua promoção, proteção e recuperação". Fica evidenciada a imprescindibilidade da prestação do serviço de forma acessível e igualitária a todos. 
Princípio da Igualdade da Assistência à Saúde: para compreender a amplitude do princípio, é necessário remeter ao art. $5^{\circ}$ da Constituição, que é a viga mestra dos direitos e garantias fundamentais, pois, ao mesmo tempo em que contém de forma expressa o direito à igualdade, traz também a inviolabilidade do direito à vida. Assim, este princípio apenas repete a determinação constitucional.

Princípio do Direito à Informação: É também na Carta Magna que este princípio encontra abrigo. Todos têm o direito de ser informados de modo claro sobre a sua saúde. É certo, porém, que o profissional da saúde deverá estar atento e avaliar os casos em que a informação poderá, ao contrário, prejudicar o estado de saúde do cidadão.

A Constituição (art. $5^{\circ}$, inc. XIV e XXXIII) garante a todos o direito a receber dos órgãos públicos informações de seu interesse particular, ou de interesse coletivo ou geral, que serão prestadas no prazo da lei, sob pena de responsabilidade, ressalvadas aquelas cujo sigilo seja imprescindível à segurança da sociedade e do Estado.

Dessa forma, o princípio da informação é também reconhecido como um dos princípios fundamentais do direito ambiental. Assim, será analisado a seguir sob o seu reflexo no meio ambiente e na saúde.

\subsubsection{Saúde, questão ambiental e o direito à informação}

De acordo com o princípio $\mathrm{n}^{\mathrm{o}} 10$ da Declaração das Nações Unidas sobre o Meio Ambiente e Desenvolvimento, adotada no Rio de Janeiro em 1992:

A melhor maneira de tratar questões ambientais é assegurar a participação, no nível apropriado, de todos os cidadãos interessados. No nível nacional, cada indivíduo terá acesso adequado às informações relativas ao meio ambiente de que disponham as autoridades públicas, inclusive informações sobre materiais e atividades perigosas em suas comunidades, bem como a oportunidade de participar dos processos decisórios. Os Estados irão facilitar e estimular a conscientização e a participação popular, colocando as informações à disposição de todos. (Atlas, 2008).

$\mathrm{O}$ direito à informação socioambiental está garantido no caput do artigo 225, que dispõe, em caso de instalação de obra ou atividade potencialmente causadora de significativa degradação ambiental, seja exigido pelo poder público estudo prévio de impacto ambiental, dando-lhe publicidade ampla, com a divulgação das informações contidas no Relatório de Impacto Ambiental (Rima). Logo, o direito de acesso às informações socioambientais pressupõe o dever do poder público de informar periodicamente a população sobre o estado do meio ambiente e sobre as ocorrências ambientais importantes. 
A Lei $n^{\circ} 7.804$, de 18/07/1989, que acrescentou o inciso XI ao art. $9^{\circ}$, da Lei $n^{\circ} 6.938$, de 31/08/1981 (Política Nacional do Meio Ambiente), obriga a prestação de informações para assegurar a todo cidadão o conhecimento sobre atividades potencialmente causadoras de impactos ambientais, compelindo o poder público a produzi-las, quando inexistentes.

Ainda neste sentido, faz-se necessário mencionar a Lei $\mathrm{n}^{\circ} 10.650 / 03$, que dispõe sobre o acesso público aos dados e informações ambientais existentes nos órgãos e entidades integrantes do Sistema Nacional do Meio Ambiente (Sisnama).

$\mathrm{O}$ artigo $2^{\circ}$ da referida Lei determina que os órgãos e entidades da Administração Pública, direta, indireta e fundações, integrantes do Sisnama, ficam obrigados a permitir o acesso público aos documentos, expedientes e processos administrativos que tratem de matéria ambiental e a fornecer todas as informações ambientais que estejam sob sua guarda, em meio escrito, visual, sonoro ou eletrônico, especialmente as relativas a: (a) qualidade do meio ambiente; (b) resultados de monitoramento e auditoria nos sistemas de controle de poluição e de atividades potencialmente poluidoras, bem como de planos e ações de recuperação de áreas degradadas; (c) acidentes, situações de risco ou de emergência ambientais; (d) emissões de efluentes líquidos e gasosos e produção de resíduos sólidos; (e) substâncias tóxicas e perigosas (incisos I, III, IV, V e VI).

Estabeleceu-se, assim, no direito brasileiro, de maneira expressa, de um lado, o direito de todos terem acesso às informações em matéria ambiental e, de outro, o dever do poder público de informar a população, sobretudo no tocante à qualidade do meio ambiente, aos resultados do monitoramento das atividades potencialmente degradadoras, às situações de risco e emergência ambientais e à emissão e depósito (incluindo o depósito por contaminação) no ar, nas águas superficiais e subterrâneas e nos solos e subsolos de substâncias tóxicas e perigosas (Machado, 1994, p. 38).

A Cetesb, como agente estadual responsável pelo controle da poluição, é entidade integrante do Sisnama (art. $6^{\circ}, \mathrm{V}$, da Lei $n^{\circ}$ 6.939/1981); está, assim, obrigada não apenas a permitir o acesso da população às informações sobre o estado do meio ambiente, como também a informar periodicamente o público a respeito das situações de risco e da contaminação do ambiente por substâncias tóxicas e perigosas, como as que se verificam nas denominadas "áreas contaminadas" do Estado de São Paulo.

É por isso que se exige do referido órgão ambiental ampla e adequada publicidade a respeito das áreas contaminadas do Estado, a fim de que todos possam ter ciência das contaminações existentes. Apenas desta forma podem posicionar-se na defesa desse bem de uso comum que é a qualidade ambiental (art. 225, caput, da CF) e dos próprios interesses 
individuais, seja na condição de vizinhos dos imóveis contaminados, imediatamente afetados pela contaminação, seja, até mesmo, na condição de adquirentes desses terrenos - já que, ao se tornarem proprietários dos imóveis, estarão sujeitos a restrições de ordem sanitária e ambiental quanto ao uso e gozo do bem e aos riscos decorrentes da contaminação.

Depois de examinar o desenvolvimento econômico e suas implicações com o meio ambiente e com a saúde humana, além da importante abordagem das questões ambientais e do desenvolvimento sustentável à luz da Constituição Federal, faz-se necessário analisar a proteção ambiental, políticas e legislação específica para atividades produtivas poluidoras, o que se fará no próximo capítulo. 


\title{
Capítulo II - Proteção Ambiental: Políticas Públicas, Instrumentos de Proteção, Legislação e Riscos Ambientais
}

\begin{abstract}
Seja qual for nossa perspectiva, vemo-nos envolvidos num problema de administração de risco. Com a difusão do risco fabricado, os governos não podem fingir que esse tipo de administração não thes compete. E eles precisam colaborar uns com os outros, uma vez que muito poucos dos riscos de novo estilo têm algo a ver com as fronteiras nacionais.
\end{abstract}

Anthony Giddens (2002, p. 43)

\section{1. Política pública de proteção ambiental}

A Lei 6.938/81 instituiu a Política Nacional de Meio Ambiente (PNMA). Esta lei foi um marco da proteção ambiental, pois anteriormente a tutela era muito fragmentada e dispersa. A Lei estabeleceu princípios, objetivos e instrumentos da Política Nacional do Meio Ambiente, trouxe definitivamente para o nosso ordenamento a Avaliação de Impacto Ambiental (AIA) e instituiu um regime de responsabilização civil objetiva para o dano ambiental, conferindo ao Ministério Público legitimação para agir nesta matéria.

A Lei da Ação Civil Pública (Lei 7.347/85) ampliou ainda mais o rol dos legitimados para agir na proteção do meio ambiente, além de fortalecer o instrumental para a reparação dos danos, prevendo até a possibilidade de instauração de inquérito civil para apurar efeitos negativos para o meio ambiente.

A PNMA é o conjunto dos instrumentos legais, técnicos, científicos, políticos e econômicos que têm por objetivo a harmonização do meio ambiente com o desenvolvimento socioeconômico. A Lei 6.938/81 prevê, como objetivo principal, a preservação, melhoria e recuperação da qualidade ambiental, entendendo-a propícia à vida e necessária à dignidade da vida humana (art. $1^{\circ}$, caput). Ainda, conceitua meio ambiente, degradação da qualidade 
ambiental, poluição e poluidor, contemplando, de forma pioneira, a responsabilização objetiva e solidária dos responsáveis ${ }^{2}$.

Com base neste raciocínio, Paulo de Bessa Antunes afirma que a PNMA deve ser compreendida como um conjunto de instrumentos legais, técnicos, científicos, políticos e econômicos, porém dentro de um contexto de promoção do desenvolvimento sustentado da sociedade e economia. Salienta, por fim, que sua implementação faz-se a partir dos princípios da própria Constituição e de leis ordinárias (Antunes, 2005, p. 95).

A Política do Meio Ambiente (art. $2^{\circ}$ ) tem por objetivo a preservação, melhoria e recuperação da qualidade ambiental propícia à vida. Visa a assegurar, no País, condições ao desenvolvimento socioeconômico, aos interesses da segurança nacional e à proteção da dignidade humana, atendidos os diversos princípios, todos eles voltados à proteção ambiental, com o intuito de consolidar uma sadia qualidade de vida. $\mathrm{O}$ art. $4^{\mathrm{o}}$ trata dos objetivos da Política Nacional, salientando o equilíbrio que deve existir entre uso e preservação ambiental. Alguns incisos merecem destaques, pois se referem à relação da empresa com o equilíbrio ecológico.

O inciso I dispõe que a PNMA visará à compatibilização do desenvolvimento econômico social com a preservação da qualidade do meio ambiente e do equilíbrio ecológico. O referido objetivo é muito importante, pois admite a conciliação entre a ordem econômica e o meio ambiente, bem como leva em consideração dois aspectos: a qualidade ambiental e o equilíbrio ecológico.

O inciso III trata do objetivo de estabelecer os critérios e padrões de qualidade ambiental, como também as normas relativas ao uso e manejo de recursos naturais. Sua relevância consiste na possibilidade de aferição da sustentabilidade de determinada região por meio dos Padrões de Qualidade Ambiental (PQA), o que influenciará as ações ambientais devidas pelas empresas, bem como baseará a eventual responsabilidade destas em relação aos impactos ambientais causados.

\footnotetext{
2 “Art. $3^{\text {o }}$ - Para os fins previstos nesta Lei, entende-se por: I - meio ambiente: o conjunto de condições, leis, influências e interações de ordem física, química e biológica, que permite, abriga e rege a vida em todas as suas formas;

II - degradação da qualidade ambiental: a alteração adversa das características do meio ambiente;

III - poluição: a degradação da qualidade ambiental resultante de atividades que direta ou indiretamente: prejudiquem a saúde, a segurança e o bem-estar da população; /.../.

e) lancem matérias ou energia em desacordo com os padrões ambientais estabelecidos;

IV - poluidor: a pessoa física ou jurídica, de direito público ou privado, responsável, direta ou indiretamente, por atividade causadora de degradação ambiental;"

"Art. 14. /... $\S 1^{\circ}$ Sem obstar a aplicação das penalidades previstas neste artigo, é o poluidor obrigado, independentemente de existência de culpa, a indenizar ou reparar os danos causados ao meio ambiente e a terceiros, efetuados por sua atividade."
} 
Por sua vez, o inciso IV do art. $4^{\circ}$ institui como meta o desenvolvimento de pesquisas e tecnologias nacionais orientadas para o uso racional de recursos ambientais. Observa-se que a aplicação de recursos nesse setor é intensa entre as empresas, visto que estas encaram o investimento como uma das principais formas de se adequarem às exigências do poder público quanto ao respeito ao meio ambiente.

O quarto objetivo está no inciso VI e refere-se à preservação e restauração dos recursos ambientais com vistas à sua utilização racional e disponibilidade permanente, de maneira a concorrer para a manutenção do equilíbrio ecológico propício à vida. A utilização racional está relacionada ao adequado manejo dos recursos naturais pelas empresas, tendo como parâmetro os princípios do desenvolvimento sustentável.

O inciso VII dispõe que a PNMA objetivará a imposição, ao poluidor e ao predador, da obrigação de recuperar e/ou indenizar os danos causados ao meio ambiente, bem como ao usuário, na forma de contribuição pela utilização de recursos ambientais com fins econômicos.

$\mathrm{O}$ art. $9^{\circ}$ elenca inúmeros instrumentos a serem utilizados na concretização da política ambiental, podendo-se destacar o estabelecimento de padrões de qualidade ambiental, o zoneamento ambiental, a avaliação de impactos ambientais, o licenciamento ambiental e a revisão de atividades efetiva ou potencialmente poluidoras, instrumentos econômicos, como concessão florestal, servidão ambiental, seguro ambiental e outros.

Dentro destas características é necessário, além de uma visão integrada juridicamente entre o bem ambiental e a proteção aos recursos naturais, incluindo uma visão sociológica do desenvolvimento desejado pelos homens, que abarca a eterna discussão entre o desenvolvimento econômico e a preservação da natureza.

Assim, os princípios e objetivos mencionados, somados às garantias constitucionais, servirão de base para a utilização dos diversos instrumentos de execução da PNMA (art. $9^{\circ}$ ). Destarte, tendo em vista a preocupação com a proteção ambiental, trabalhar-se-ão adiante os dispositivos legais de proteção do meio ambiente e, posteriormente, os instrumentos de defesa.

É importante, ainda, destacar que a Constituição de 1988, especificamente o Capítulo VI do título VIII, com o art. 225, é considerada um dispositivo moderno, um dos mais adiantados em matéria de proteção ambiental, conforme mencionado anteriormente. 


\subsubsection{Dispositivos legais de proteção ao meio ambiente}

Na Constituição Federal podem-se identificar vários dispositivos voltados à saúde e à proteção ambiental, além de uma legislação infraconstitucional esparsa, ou seja, por tipo de assunto; por exemplo, dispõe o inciso VIII do art. 220 da CF que compete ao Sistema Único de Saúde (SUS), além de suas atribuições, colaborar para a proteção ao meio ambiente, nele compreendido o do trabalho.

Quanto à manifestação do pensamento, determina que a criação, a expressão e a informação, sob qualquer forma, processo ou veículo, não sofrerão nenhuma restrição, porém compete à lei federal, estabelecer meios que garantam à pessoa e à família a possibilidade de se defenderem de programas ou programações de rádio e televisão que contrariem os princípios, bem como de produtos, práticas e serviços que possam ser nocivos à saúde e ao meio ambiente (art. 220, $\S 3^{\circ}$, inciso II da CF).

Inicialmente, foi a Lei 6.938/81, de PNMA, que conferiu legitimidade ao Ministério Público para atuar propondo ação de responsabilidade civil e criminal por danos causados ao meio ambiente.

Assim, o art. $14 \S 1^{\circ}$ prevê que o Ministério Público da União e dos Estados terá legitimidade para propor ação de responsabilidade civil e criminal por danos causados ao meio ambiente. Posteriormente, a Lei da Ação Civil Pública (Lei 7.347/85) reforçou e ampliou a proteção ambiental e o papel do Ministério Público.

A Constituição Federal de 1988 recepcionou as duas leis anteriores, conferiu ao Ministério Público a defesa de outros interesses difusos coletivos (art. 129, III) e dedicou todo um capítulo ao meio ambiente - ampliando, ainda, a proteção ambiental -, conferindo a qualquer cidadão legitimidade para propor ação popular que vise a anular ato lesivo ao meio ambiente, dentre outras hipóteses (art. 5\%, LXXIII).

O Código de Defesa do Consumidor (Lei 8.078/90) definiu os interesses metaindividuais e estabeleceu uma aplicação conjunta, em matéria processual, com a Lei da Ação Civil Pública.

Para compreensão de interesses meta-individuais é importante mencionar as suas diversas acepções técnicas, conforme um estudo que chegou à denominada "escala crescente de coletivização", de Rodolfo de Camargo Mancuso (2000, p. 78):

- $1^{\circ}$ Interesses individuais - são os interesses do indivíduo considerado isoladamente; 
- $2^{\circ}$ Interesses sociais - é o interesse que consulta à maioria da sociedade civil. Este interesse reflete o que a sociedade entende por "bem comum"; o anseio de proteção à res publica; a tutela daqueles valores e bens mais elevados e outros. Significa o exercício coletivo de interesses individuais (ex.: extração de areia de um rio, causando um dano ecológico ao rio e à população ribeirinha) (Mancuso, 2000, pp. 25-7).

- $3^{\circ}$ Interesses coletivos - são os interesses referidos a valores de categorias sociais ou grupos: associações, sindicatos ou conselho regional de profissão (OAB, CRM, CREA e outros);

- $4^{\circ}$ Interesses públicos ou gerais - são os interesses da coletividade representada pelo Estado, tendo como baliza o bem comum: a segurança pública, a saúde pública;

- $5^{\circ}$ Interesses difusos - são interesses de número indeterminado de pessoas. Excedem o interesse público ou geral, reportando-se ao homem, à nação, ao justo etc.

Segue-se com os ensinamentos do mesmo autor, que acrescenta ao direito difuso as seguintes características: a indeterminação dos sujeitos, a indivisibilidade do objeto, a intensa litigiosidade interna e a transição ou mutação no tempo e no espaço.

- Indeterminação dos sujeitos: Não há um titular individualizado. Trata-se do interesse meta-individual, aquele que rege a relação entre a coletividade e o bem da vida (bem difuso). Esta característica fica muito clara no caput do art. 225, no momento em que o legislador utiliza-se da expressão "todos" para o sujeito do direito;

- Indivisibilidade do objeto: pode decorrer da substância do bem ou da disposição legal;

- Intensa litigiosidade interna: dentro das questões ambientais a litigiosidade é marcante devido aos diversos tipos de interesse que o meio ambiente desperta. Pode citar como exemplo uma imensa área de mata atlântica, onde um grande empreendedor resolve criar um condomínio de luxo. Neste caso, há o interesse na preservação da mata e o interesse econômico.

- Transição ou mutação no tempo e no espaço: $O$ conteúdo dos interesses difusos não é estático: ele muda de acordo com a situação fática. Ex: o não recolhimento do lixo de áreas carentes de um 
determinado município. Neste momento há um direito difuso para salvaguardar. Passado algum tempo, a Prefeitura começa a recolher o lixo, mas o deposita em um "lixão" onde as crianças carentes vão procurar comida. Desta forma, aparece outro conteúdo de direito difuso.

Por sua vez, a Lei 9.605/98, conhecida como Lei dos Crimes Ambientais, dispõe sobre as sanções penais e administrativas derivadas de condutas e atividades lesivas ao meio ambiente, completando o ciclo de proteção integral nas esferas administrativa, civil e penal, conforme se verificará adiante.

$\mathrm{O}$ art. $225, \S 3^{\circ}$ da Carta Magna, ao determinar a tríplice punição do poluidor, deixa claro que existem estas três esferas de proteção do meio ambiente, porém deve-se ressaltar que não há bis in idem na regra da cumulação de sanções (penais, civis e administrativas), pois estas protegem objetos distintos e estão sujeitas a regimes jurídicos diversos, conforme se passará a analisar a seguir.

\subsection{1 a) Tutela Civil - aspectos da responsabilidade civil ambiental}

A responsabilidade civil no direito comum, quanto ao regime da responsabilidade extracontratual, é subjetiva ou aquiliana, uma vez que leva em conta a culpa ou dolo do agente que provocou o dano.

O meio ambiente constitui um direito difuso indisponível e, portanto, a sua defesa constitui matéria de interesse público.

A responsabilidade civil pelo dano ambiental é extracontratual, porque decorre do dever de indenizar; é objetiva, pois independe da análise de culpa do agente; e solidária, com base no artigo $225, \S 3^{\circ}$ da Constituição Federal de 1988, combinado com o artigo $3^{\circ}$, IV e 14, $\S 1^{\circ}$ da Lei 6.938/81 e com o artigo 942, caput, segunda parte do Código Civil (Lei $10.406 / 02)$.

A responsabilidade extracontratual caracteriza-se pelo fato de que, independentemente de qualquer vínculo com os afetados, o poluidor é obrigado a indenizar os danos causados ao meio ambiente em si e a terceiros afetados pela conduta danosa.

A responsabilidade objetiva está disposta no art. $14, \S 1^{\circ}$ da Lei $6.938 / 81$, ou seja, para pleitear a reparação do dano ambiental, o autor deve demonstrar a ação ou omissão do réu, o evento danoso e o nexo de causalidade, de modo que a ausência de culpa ou, ainda, a licitude 
da atividade não impedem a reparação. Ademais, segundo Édis Milaré, faz-se prescindível a investigação da culpa, é irrelevante a licitude da atividade e não se aplicam as causas de exclusão de responsabilidade civil (Milaré, 2004, p. 387).

Por sua vez, a defesa do poluidor deve alegar que exerce atividade lícita devidamente autorizada pelo órgão competente, porém isto não o exime da reparação do dano, se este ocorreu em virtude da sua atividade.

Assim, a responsabilidade acatada é a objetiva sob a modalidade do risco integral, pela qual é irrelevante a existência do caso fortuito ou da força maior como causas excludentes. Desta forma, ocorrido o dano, seja em virtude de uma falha técnica ou humana, por obra do acaso ou, ainda, por força da natureza, deve o empreendedor responder e, se possível, voltar contra o verdadeiro causador, pelo direito de regresso, quando for fato gerado por terceiro.

A Lei $6.453 / 77$ dispõe sobre a responsabilidade civil por danos nucleares e da responsabilidade criminal por atos relacionados a atividades nucleares. A referida Lei estabeleceu a responsabilidade civil objetiva ao determinar, no art. $4^{\circ}$, que será exclusiva do operador da instalação nuclear, independentemente da existência de culpa, a responsabilidade civil pela reparação de dano causado por acidente nuclear.

Surge a responsabilidade solidária quando se verifica que há mais de um empreendedor envolvido no evento danoso. Assim, a reparação pode ser exigida de todos ou de qualquer um, segundo as regras da solidariedade, cabendo ao que pagar pelo dano a ação de regresso contra os outros co-responsáveis - aí, sim, pela via da responsabilidade subjetiva, em que poderão discutir a parte que cabe a cada um.

A jurisprudência entende, todavia, que é possível ser proposta ação civil pública contra o responsável direto, contra o indireto ou contra ambos, havendo responsabilidade solidária.

Incluir, no entanto, o Estado como solidariamente responsável pelos danos provocados por terceiros, já que é seu dever fiscalizar e impedir que os danos aconteçam, é algo mais complexo. Há posicionamento entendendo não ser possível, pois se estaria punindo a própria vítima da poluição, o povo.

Por outro lado, Solange Teles da Silva (2007, p. 8), quando trata da participação do Poder Judiciário nas políticas públicas no meio ambiente urbano, destaca a sua importância no controle judicial de omissões do poder público em relação à execução daquelas políticas. A autora explica e exemplifica que cabe ao Judiciário, por meio de ações judiciais, determinar que os governos adotem medidas de preservação do meio ambiente, tais como a implantação 
de sistema de tratamento de esgoto ${ }^{3}$ ou de resíduos sólidos urbanos ${ }^{4}$ ou, ainda, a implantação definitiva de espaço territorial protegido, já instituído por norma, ou a preservação de um bem de valor cultural.

Dessa forma, conclui que o poder público tem o dever de agir para alcançar os objetivos e metas previstos em normas constitucionais e infraconstitucionais; e o Poder Judiciário impõe a execução das políticas públicas que foram estabelecidas no ordenamento legal.

\subsection{1 b) Tutela Administrativa}

A Lei 9.605/98, conhecida como Lei dos Crimes Ambientais, dispõe um capítulo específico, ou seja, do art. 70 ao art. 76, contendo regras gerais relacionadas às infrações administrativas. O Decreto 3.179/99 regulamenta a lei e possui várias disposições sobre a apuração dessa responsabilidade.

Considera-se infração administrativa ambiental, capaz de gerar a responsabilidade administrativa, toda ação ou omissão que viole as regras jurídicas de uso, gozo, promoção, proteção e recuperação do meio ambiente (art. 70, caput, da Lei 9.605/98).

\footnotetext{
3 "AÇÃO CIVIL PÚBLICA - Meio idôneo para compelir o Poder Público a tratamento de esgoto Arbitramento de prazo para cumprimento da obrigação determinado na sentença à luz da prova técnica Providência sensata, tendo em vista a força orçamentária do Município - Recurso não provido" (TJSP $-2^{\mathrm{a}}$ Câmara Civil - Apelação Cível 158.646-1/0 - j. 26.5.1992 - v.u. - rel. Des. Cezar Peluso). "AÇÃO CIVIL PÚBLICA - Demanda proposta pelo Ministério Público visando a obrigar a Municipalidade a efetuar prévio tratamento antes de lançar o esgoto em cursos d'água, com restauração do ambiente degradado - Carência da ação decretada em primeira instância, sob o fundamento de interferência no Poder Executivo - Possibilidade da demanda e da atuação ministerial na forma do artigo 129, III, da Constituição Federal e Lei n. 7.347/85 Pretensão buscando coibir degradação de meio ambiente e de danos à saúde pública, não podendo ser obstada sob o manto da discricionariedade administrativa - Sentença de carência afastada, com determinação para prosseguimento da ação - Recurso ministerial provido. Possível o ajuizamento de ação civil pública, pelo Ministério Público, visando a obstar ato de Municipalidade de despejar esgoto, sem tratamento, em curso d'água, evitando-se a degradação do meio ambiente e danos à saúde pública" (Apelação Cível n. 47.991-5 - General Salgado - $1^{\text {a }}$ Câmara de Direito Público - rel. Luís Ganzer - 16.11.1999 - v.u.). "MUNICÍPIO - Lançamento de esgoto in natura - Possibilidade jurídica do pedido - Existência - É admissível ação civil pública para obstar que município, comissiva ou omissivamente, continue lançando esgoto in natura em corpo de água, por estar tal medida prevista em lei, notadamente contra aquele que tem o dever legal de proteger o meio ambiente e combater a poluição em qualquer de suas formas - ilícita, porém, é determinação judicial para que reative ele estação de tratamento de esgoto, por descaber ao Poder Judiciário, sob pena de inversão de competência, dizer qual obra deva ou não o Executivo realizar, para impedir ou minorar a poluição ambiental - Inteligência da Constituição Federal de 1988, artigos 2 ${ }^{\circ}$, 23, inciso VI, e 225, Constituição Bandeirante, artigo 208, e da Lei n. 7.347, de 24.7.1965, artigo $1^{\circ}$, inciso I - Recurso parcialmente provido" (Agravo de Instrumento n. 271.588-5 São José do Rio Pardo $-5^{\text {a }}$ Câmara de Direito Público - Relator: Xavier de Aquino -3.10.2002 - v.u.).

4 “AÇÃO CIVIL PÚBLICA - Meio Ambiente - Degradação - Comprovação - Alegação de impossibilidade financeira do Município para regular destinação final de lixo urbano - Irrelevância - Aterro instalado sem observância das medidas devidas - Art. 225, §1 ${ }^{\circ}$, IV, da Constituição Federal e do Decreto Estadual n. 8.468/76 - Prioridade social da Administração Pública - Recurso não provido" (TJSP - $7^{\mathrm{a}}$ Câmara Civil 229.105-1/3 - j. 9.8 .1995 - v.u. - rel. Des. Leite Cintra).
} 
Quando ocorre uma infração administrativa, lavra-se um auto de infração ambiental apontando a regra jurídica violada, ocorrendo a apuração em processo administrativo próprio. Poderá ser imposta a sanção administrativa pelo órgão competente, devendo sempre vir prevista em lei, ou seja, obedecendo ao princípio da legalidade.

É importante esclarecer que a sanção administrativa pode ser aplicada sem prejuízo das sanções civis e penais e pode apresentar-se sob a forma de advertência, multa simples ou diária, apreensão dos animais, produtos e subprodutos da fauna e flora, instrumentos, equipamentos ou veículos de qualquer natureza utilizados na infração; destruição ou inutilização do produto; suspensão de venda e fabricação do produto; embargo da obra ou atividade; demolição de obra; suspensão parcial ou total de atividades e restritiva de direitos (art. 72 da Lei 9.605/98).

A Cetesb é a agência do governo do Estado de São Paulo responsável pelo controle, fiscalização, monitoramento e licenciamento de atividades geradoras de poluição, com a preocupação fundamental de preservar e recuperar a qualidade das águas, do ar e do solo.

Criada em 24 de julho de 1968, pelo Decreto 50.079, com a denominação inicial de Centro Tecnológico de Saneamento Básico, o Cetesb incorporou a Superintendência de Saneamento Ambiental (Susam), vinculada à Secretaria da Saúde. Esta, por sua vez, absorvera a Comissão Intermunicipal de Controle da Poluição das Águas e do Ar (CICPAA) que, desde agosto de 1960, atuava nos municípios de Santo André, São Bernardo do Campo, São Caetano do Sul e Mauá, na região do ABC da Grande São Paulo (Cetesb, 2008).

A Cetesb foi constituída por autorização da Lei Estadual 118, de 29 de junho de 1973, tendo recebido, naquela oportunidade, a denominação de Companhia Estadual de Tecnologia de Saneamento Básico. Posteriormente, por meio do Decreto 5.993, de 16 de abril de 1975, o órgão ambiental passou a denominar-se Companhia Estadual de Tecnologia de Saneamento Básico e de Defesa do Meio Ambiente, sendo que, pela Assembléia Extraordinária de 17/12/76, teve sua denominação alterada para Companhia de Tecnologia de Saneamento Ambiental (Cetesb).

Segundo informações no seu sítio virtual na Internet, a Cetesb tornou-se um dos 16 centros de referência da Organização das Nações Unidas (ONU) para questões ambientais, atuando em estreita colaboração com os 184 países que integram este organismo internacional. Tornou-se, também, uma das cinco instituições mundiais da Organização Mundial de Saúde (OMS) para questões de abastecimento de água e saneamento, além de órgão de referência e consultoria do Programa das Nações Unidas para o Desenvolvimento (PNUD) em questões ligadas a resíduos perigosos na América Latina. 
Todavia, com relação às atribuições desse órgão ambiental, analisando o Decreto 5.993/76, verifica-se que incumbe à Cetesb “o exercício do controle da qualidade do meio ambiente - água, ar e solo - em todo o território do Estado de São Paulo” (art. $2^{\circ}$ ), sendo que, nos termos do art. $3^{\circ}$, na qualidade de órgão delegado do governo do Estado de São Paulo, esta deve:

I - exercer as atividades e prerrogativas ao controle de poluição das águas, fixadas pelo Decreto-Lei 195-A, de 19 de fevereiro de 1970, e as relativas ao controle de poluição do ar, fixadas pelo Decreto-Lei 232, de 17 de abril de 1970, incumbindo-lhe o efetivo exercício do controle da qualidade do meio ambiente - água, ar e solo - em todo o território estadual, além de outras atividades úteis ou necessárias ao cumprimento de suas finalidades, inclusive o poder de polícia administrativa, inerente e indispensável ao bom desempenho de seus serviços;

II - efetuar o controle da qualidade do meio ambiente - água, ar e solo

- através de medidas preventivas ou corretivas de emissão ou assimilação de resíduos poluidores, sob qualquer forma de matéria ou energia;

III - efetuar o controle de qualidade das águas destinadas ao abastecimento público e a outros usos;

IV - efetuar exames e análises de resíduos sólidos, líquidos e gasosos.

No Capítulo IV deste trabalho a Cetesb será analisada sob outro aspecto, uma vez que este órgão ambiental está sendo processado na ACP (estudo de caso) que busca apurar a responsabilidade pelos danos ambientais causados no Bairro da Vila Carioca, na área ocupada pela Shell.

\subsection{1 c) Tutela Penal}

Luís Paulo Sirvinskas entende que a tutela do meio ambiente continua sendo uma necessidade indispensável. $\mathrm{O}$ autor salienta que a medida penal tem por escopo prevenir e reprimir condutas praticadas contra a natureza, porém adverte que a moderna doutrina penal defende a abolição da pena privativa de liberdade, com a conseqüente substituição por penas alternativas. O legislador da Lei 9.605/99 (Lei de Crimes Ambientais) seguiu esta tendência (Sirvinskas, 2005).

$\mathrm{O}$ autor define dano ambiental como sendo toda a agressão contra o meio ambiente causada por atividade econômica potencialmente poluidora ou por ato comissivo ou omissivo praticado por qualquer pessoa (Sirvinskas, 2005, p. 108).

Por sua vez, Valery Mirra conceitua dano ambiental como: 
toda degradação do meio ambiente, incluindo os aspectos naturais, culturais e artificiais que permitem e condicionam a vida, visto como bem unitário imaterial coletivo e indivisível, e dos bens ambientais e seus elementos corpóreos e incorpóreos específicos que o compõem, caracterizadora da violação do direito difuso e fundamental de todos à sadia qualidade de vida em um ambiente são e ecologicamente equilibrado (2005, p. 89).

A Lei 9.605/98 pune a ação e também a omissão em relação ao dano ambiental, isto é, pune aquele que, sabendo da conduta criminosa de outrem, não impede sua prática, quando poderia agir para evitar o fato. A lei prevê uma série de tipos penais que serão apenados a título de dolo e outros acerca dos quais se admite a modalidade culposa (os tipos culposos aparecem nos arts. 38, 40, 41, 49, 54, 56, 62, 67 e 68).

A inovação dessa lei é a imputação penal não só da pessoa física, mas também da pessoa jurídica, responsabilizada administrativa, civil e penalmente pelas condutas danosas ao ambiente, quando houver decisão do representante legal ou contratual ou de órgão colegiado no interesse da entidade (art. $2^{\circ}$ ).

Existe crime doloso se o agente teve vontade e consciência de praticá-lo e/ou assumiu o risco de produzir o resultado. No caso da culpa, se agiu com imprudência, negligência ou imperícia.

A técnica legislativa utilizada, em muitos tipos, foi a da norma penal em branco. Assim, a conduta proibida muitas vezes está prevista de modo vago, dependendo de uma complementação por outros dispositivos legais ou atos normativos.

Existem crimes ambientais que podem ser enquadrados nos ditos crimes de perigo, para os quais é suficiente a existência da mera probabilidade do dano para que se configure a ocorrência do crime. Outros tipos podem configurar os crimes de mera conduta, para os quais a consumação se dá com a simples ação ou omissão, não havendo necessidade da ocorrência de nenhum resultado naturalístico da ação.

As sanções são advertência, multa, multa diária, apreensão e destruição de bens, suspensão de atividades, reparação de danos causados e afins.

Com relação à parte processual, é importante observar que o legislador não foi explícito com referência ao rito e regras processuais penais, dispondo apenas três artigos (os arts. 26 a 28) a respeito. Assim, em caso de lacunas na lei, estas devem ser preenchidas por outros instrumentos legais.

$\mathrm{O}$ art. 27, por exemplo, prevê a possibilidade de compor os danos ambientais antecipadamente à realização de transação penal nas infrações de menor potencial ofensivo; em nenhum momento buscou-se explicitar como isto ocorreria, quais seus pressupostos e 
alcance, porém, na prática, verifica-se a aplicação da transação penal, nos termos da Lei 9.099/95 - Lei dos Juizados Especiais Cíveis e Criminais.

Para finalizar este ponto, entende-se que o dano ambiental, na ótica criminal, tem de ser direto e constatado, não podendo ser aceito o dano presumido (que não exige, por óbvio, compromisso de restauração do meio ambiente alterado).

\subsection{Riscos ambientais}

Sérgio Cavalieri Filho esclarece juridicamente que

risco é perigo, é probabilidade de dano, importando, isso, dizer que aquele que exerce uma atividade perigosa deve-lhe assumir os riscos e reparar o dano dela decorrente. A doutrina do risco pode ser, então, assim resumida: todo prejuízo deve ser atribuído ao seu autor e reparado por quem o causou, independentemente de ter ou não agido com culpa. Resolve-se o problema na relação de causalidade, dispensável qualquer juízo de valor sobre a culpa do responsável, que é aquele que materialmente causou o dano (Cavalieri Filho, 2000, p. 143).

As sociedades modernas criaram riscos. Estes chegaram atualmente a tal dimensão que os meios pelo quais tentamos lutar contra eles são muito ineficientes, gerando intranqüilidade e busca pelo conhecimento e ordenamento, para conter tais implicações e organizar a interação entre indivíduo, sociedade e seu ecossistema.

Isso se deve à circunstância de que, na emergência do capitalismo industrial, ao mesmo tempo em que eram proporcionadas condições de desenvolvimento tecnológico, apropriação de bens e livre acumulação econômica, a sociedade era exposta a uma proliferação de ameaças originadas de diversas fontes, que muitas vezes eram de difícil identificação (Leite; Ayala, 2004, p. 11).

Nesta fase do desenvolvimento da modernização, as transformações produzem consequiências que expõem as instituições de controle e proteção das sociedades industriais à crítica, fatores que constituem, para Beck, a sociedade de risco.

Beck esclarece o conceito: "uma fase do desenvolvimento da sociedade moderna onde os riscos sociais, políticos, ecológicos e individuais criados pela ocasião do momento de inovação tecnológica escapam das instituições de controle e proteção da sociedade industrial" (Cavalieri Filho, 2000, p. 143).

Diante do novo modelo de organização social, o perfil dos riscos distancia-se dos riscos profissionais e empresariais do Estado nacional, identificando-se agora a ameaças globais, supranacionais, sujeitas a uma nova dinâmica política e social (Beck, 1998, p. 19). 
$\mathrm{Na}$ sociedade de risco destacam-se algumas características: os riscos e perigos excedem os limites temporais e espaciais e as formas de degradação ambiental não estão limitadas em termos de espaço ao âmbito do seu impacto, mas, ao contrário, trata-se de riscos globais no âmbito de seu alcance. Não há certeza nem garantia de responsabilização e indenização.

Chernobyl e a catástrofe nuclear representam hoje a imagem de um exemplo negativo, que reconduz a pretensa onipotência das instituições de controle e dogma da infalibilidade tecnológica ao mundo terreno das falhas de segurança, da incapacidade de previsão antecipada de suas consequiências e das limitações técnicas das instituições de controle e das instâncias de decisão (Leite; Ayala, 2004, p. 19).

Por oportuno, tendo em vista o objeto de estudo neste trabalho, os problemas ambientais associados à presença de solos contaminados, por exemplo, no Brasil, começaram a ser reconhecidos durante a década de 1980, mas foi somente a partir de meados do decênio seguinte que respostas do poder público começaram a ser estruturadas.

Segundo Luís Enrique Sánchez, o Estado de São Paulo foi pioneiro, ao estabelecer um programa de capacitação de recursos humanos e de desenvolvimento de ferramentas de gestão, com a cooperação do governo alemão. Esta ação governamental vem se dando via diferentes iniciativas, como a constituição de um cadastro de áreas contaminadas e a introdução de novos requisitos legais, que serão tratados a seguir. Outra que o autor destaca é a existência de diversos projetos de remediação em andamento, bem como o fato de que várias empresas já adotam procedimentos de precaução antes da realização de transações imobiliárias que envolvam terrenos potencialmente contaminados. Este assunto será abordado de forma sucinta, uma vez que não corresponde ao objetivo do trabalho.

\section{3. A regulação de risco e das atividades produtivas poluidoras}

O desenvolvimento tecnológico e a industrialização são processos que deveriam estar voltados para a melhoria da qualidade de vida e bem-estar coletivos, como parte importante do crescimento econômico. Todavia, a busca incessante de novas tecnologias e da elevação da produtividade não gera apenas benefícios. Os aspectos não desejados, e muitas vezes não previstos, das atividades produtivas resultam em riscos ou danos aos próprios trabalhadores, à saúde pública, ao meio ambiente, ao patrimônio etc. São as chamadas externalidades negativas de um processo. 
O desenvolvimento da indústria em São Paulo desde seus primórdios se configurou um problema de risco à saúde e ao meio ambiente. Uma interessante consulta à legislação paulista daquela época (que coincide com o início do crescimento populacional mais intenso da cidade de São Paulo), em especial, do Código Sanitário de 1894, mostra as primeiras manifestações efetivas do poder público no sentido de conter os efeitos danosos ao ambiente que a nascente indústria e a urbanização não planejada começavam a causar (Valentim, 2005, p. 65).

Os arts. 313 e 314 deste centenário documento legal já apresentavam a preocupação com os efeitos da expansão urbana sobre os recursos hídricos: "As matas existentes nas cabeceiras [dos mananciais] deverão ser conservadas do melhor modo possível" e "Deverão ser absolutamente proibidas habitações acima das represas e tomadas d'água". Além de proteger as áreas de mananciais, a legislação tentava evitar o lançamento de resíduos nos corpos d'água, conforme dispõe no art. 82: "Deve ser proibido o despejo de matérias residuais nos cursos d'água potável dentro e fora dos povoados".

O Código previa exceções quanto à proibição do lançamento de efluentes: "Na falta de canalização de esgotos, os resíduos poderão ser lançados nos rios, mas depois de purificados" (art. 173); porém, acrescenta o legislador, esse despejo não deveria ocorrer de qualquer forma: “O lançamento no caso deve ser feito sempre no meio do rio, onde a corrente é mais forte e também à jusante da povoação" (art. 174).

Com relação ao uso do solo urbano para fins industriais, nota-se a intenção de legislar não somente quanto à localização das atividades produtivas como também ao destino dos rejeitos: "As autoridades locais deverão determinar onde devem ser construídas as fábricas e oficinas, e para onde deverão ser removidas as que são prejudiciais” (art. 154); “A natureza das indústrias regula o maior e o menor afastamento das fábricas em relação aos centros populosos" (art. 155) e "Os resíduos sólidos, que não forem aproveitáveis para outras indústrias, serão incinerados no estabelecimento ou removidos para fora do limite urbano" (art. 175).

São Paulo viu crescer seu parque fabril com uma rapidez vertiginosa. Como vimos, em 1968 foi criado o Centro Tecnológico de Saneamento Básico (Cetesb), a instituição era, inicialmente, voltada para o desenvolvimento de bases tecnológicas relacionadas a saneamento básico, porém somente em 1976 o Estado ganhou legislação específica, que estabeleceu o Sistema de Prevenção e Controle da Poluição do Meio Ambiente, dando ao poder público competência para a regulação das atividades potencialmente causadoras da poluição das águas, ar e do solo. 
Assim, o poder público começou a ter condições mais efetivas para intervir em situações ou atividades que pudessem tornar o ambiente "impróprio, nocivo ou ofensivo à saúde; inconveniente ao bem-estar público; prejudicial à segurança, ao uso e gozo da propriedade e às atividades normais da comunidade". Assim, começou-se a exigir licenças ambientais para todas aquelas atividades consideradas "fontes de poluição" (Lei Estadual 997/76).

O Decreto Estadual 8.468/76, regulamento com 115 artigos e cinco anexos, estabelece várias regras de prevenção e controle da poluição do meio ambiente, considerando "poluente toda e qualquer forma de matéria ou energia lançada ou liberada nas águas, no ar ou no solo" $\left(\operatorname{art.} 3^{\circ}\right)$.

Os arts. 51, 52 e 53 tratam da poluição do solo, proibindo o aterro de borras tóxicas de qualquer produto petroquímico que viesse a contaminar o solo, a água e o $\mathrm{ar}^{5}$.

Em 1978 entrou em vigor a Lei 1.817/78, que estabeleceu os objetivos e as diretrizes do desenvolvimento industrial metropolitano e disciplinou o zoneamento industrial, a localização, a classificação e o licenciamento de estabelecimentos industriais. Compreendia a implantação, a ampliação de área construída e a alteração do processo produtivo de estabelecimentos industriais localizados ou que viessem a se localizar na Região Metropolitana da Grande São Paulo, todos devendo reger-se pelas disposições desta lei.

Para o zoneamento industrial, mediante o "disciplinamento do uso e ocupação do solo para fins de localização industrial”, a Lei estabeleceu três categorias de zonas de uso industrial: estritamente industrial (ZEI), predominantemente industrial (Zupi) e de uso diversificado (ZUD).

$\mathrm{O}$ art. 14 advertia que competia ao interessado declarar quais os tipos de atividade do estabelecimento industrial e os códigos nos quais se enquadrava, sob pena de responder por erro ou a falsidade do documento, o que podia acarretar a cassação das licenças eventualmente expedidas. Para obter tal documento, era facultado ao interessado obter

\footnotetext{
5 “Artigo 51 - Não é permitido depositar, dispor, descarregar, enterrar, infiltrar ou acumular no solo resíduos, em qualquer estado de matéria, desde que poluentes, na forma estabelecida no art. $3^{\circ}$ deste regulamento.

Artigo 52 - O solo somente poderá ser utilizado para destino final de resíduos de qualquer natureza, desde que sua disposição seja feita de forma adequada, estabelecida em projetos específicos de transporte e destino final, ficando vedada a simples descarga ou depósito, seja em propriedade pública ou particular.

Parágrafo único - Quando a disposição final, mencionada neste artigo, exigir a execução de aterros sanitários, deverão ser tomadas medidas adequadas para proteção das águas superficiais e subterrâneas, obedecendo-se normas a serem expedidas pela Cetesb.

Artigo 53 - Os resíduos de qualquer natureza, portadores de patogênicos ou de alta toxicidade, bem como inflamáveis, explosivos, radioativos e outros prejudiciais, a critério da Cetesb, deverão sofrer, antes de sua disposição final no solo, tratamento e/ou condicionamento adequados, fixados em projetos específicos, que atendam aos requisitos de proteção de meio ambiente."
} 
certificado de enquadramento do estabelecimento industrial junto ao órgão ou entidade estadual competente para exercer o controle da poluição do meio ambiente.

Por sua vez, pelo art. 15, ficavam proibidas "a implantação, a alteração do processo produtivo e a ampliação de área construída dos estabelecimentos industriais”, considerados incompatíveis com o interesse metropolitano.

A regulação da localização industrial começava a se intensificar. Assim é que, em 1978, foi proibida a instalação de indústrias potencialmente poluidoras nas estâncias hidrominerais, climáticas e balneárias do Estado (Lei Estadual 1.563/78); no ano seguinte, vetou-se a instalação e o funcionamento de indústrias de celulose e papel na bacia de drenagem do Rio Paranapanema (Lei Estadual 2.090/79).

Em 1986, por meio da Lei Estadual 4.963, proibiu-se a instalação de indústrias químicas, de produtos inflamáveis ou explosivos e de usinas de concreto na Região Metropolitana de São Paulo.

Em 1987, foram proibidas a implantação, alteração do processo produtivo e ampliação da área construída de diversos tipos de estabelecimentos industriais na bacia do Rio MojiGuaçu (Lei Estadual 5.650/87 de 28/04/87). Por serem consideradas incompatíveis com o meio ambiente, indústrias como as que produziam organoclorados, herbicidas, produtos de limpeza e polimento, desinfetantes, inseticidas, germicidas, fungicidas, concentrados aromáticos, adubos, fertilizantes, tintas, vernizes, solventes e celulose ficaram impedidas de se instalar ou se expandir na região (Valentim, 2005, p. 71).

Em seguida, nove anos após serem definidas diretrizes para o desenvolvimento industrial da região metropolitana, foram estabelecidas normas para o interior do Estado, via Lei Estadual 5.597/87. A compatibilidade entre as atividades industriais e a proteção ambiental deveria ocorrer com base na definição de zonas destinadas à instalação de indústrias. As mais preocupantes em termos de risco ambiental, consideradas de extrema periculosidade, eram os pólos petroquímicos, carboquímicos, cloroquímicos e usinas nucleares.

$\mathrm{O}$ art. $5^{\circ}$ da referida Lei, para efeito de sua localização nas diferentes categorias, dispõe sobre a classificação das indústrias, conforme o grau de risco ambiental de sua atividade, nos seguintes tipos: I1 - Indústrias virtualmente sem risco ambiental; I2 - Indústrias de risco ambiental leve; I3 - Indústrias de risco ambiental moderado; I4 - Indústrias de risco ambiental alto; I5 - Indústrias e pólos petroquímicos, carboquímicos e cloroquímicos, usinas nucleares e outras fontes não-industriais de grande impacto ambiental ou de extrema periculosidade. 
A Lei 9.472/96 também disciplina o uso de áreas industriais e dá outras providências no que tange à ampliação de área construída ou à alteração do processo produtivo, com exigência de prévia avaliação de impacto ambiental da atividade na forma da legislação pertinente. Seu art. $4^{\circ}$ estabelece que o órgão estadual responsável pelo controle da poluição ambiental deverá observar vários aspectos, demonstrando a preocupação do legislador com o passivo ambiental:

- “a adoção de medidas para avaliação, controle e prevenção da poluição ambiental de suas atividades nos vários componentes do meio ambiente;"

- "o gerenciamento do uso e conservação das formas de energia utilizadas;"

- "o uso racional e econômico de matéria-prima e de transporte;"

- “a minimização, reciclagem, tratamento ou disposição segura de resíduos sólidos, líquidos e gasosos;"

- "o aperfeiçoamento de métodos de produção, com o objetivo de torná-los menos agressivos ao meio ambiente;"

- "o planejamento de produtos, com vistas a eliminar ou minimizar seus efeitos negativos sobre o meio ambiente;"

- "a conscientização, treinamento e motivação dos funcionários quanto aos cuidados para com a preservação ambiental;"

- “a informação ao público externo sobre as atividades da instituição e relacionamento com a comunidade localizada em seu entorno e, também, do direito de conhecimento de riscos involuntários a que está submetida.”

A Lei Estadual 9.999/98, que altera as Leis 1.817/87 e 9.472/96 e disciplina o uso de áreas industriais, admite os usos residencial, comercial, de prestação de serviços e institucional em Zonas de Uso Predominantemente Industrial (Zupis) que tivessem "sofrido descaracterização significativa do uso industrial" e não apresentassem contaminação da área. Para avaliar este último quesito, tornou-se necessário, a partir de então, que todo empreendimento não-industrial que pretendesse instalar-se nessas zonas contasse com parecer técnico do órgão ambiental estadual, além do atendimento às exigências constantes da legislação municipal (art. $1^{\circ}$ ). Desde então, o poder público passou a olhar mais diretamente para as relações entre passivos ambientais, industrialização e expansão urbana (Valentim, 2005, p. 72).

O Decreto 47.397/02 dispõe significativas alterações na legislação relativa a prevenção e controle da poluição do meio ambiente, ou seja: a expedição de licença ambiental 
de instalação fica condicionada à não existência de indícios ou evidências de que ocorrerá lançamento ou liberação de poluentes nas águas, ar ou solo; para alguns estabelecimentos considerados "fontes de poluição" (como loteamentos ou desmembramentos de imóveis, condomínios horizontais ou verticais e conjuntos habitacionais, independentemente do fim a que se destinam), torna-se necessário comprovar que a área objeto do licenciamento não apresenta impedimentos à ocupação proposta, sob o ponto de vista ambiental e de saúde pública, ficando o licenciamento condicionado ao equacionamento das pendências ambientais; e, no caso daquelas áreas objeto de deposição, aterramento ou contaminação com materiais nocivos à saúde pública, é exigido seu saneamento previamente ao pedido de licença de instalação.

Por sua vez, o Decreto Estadual 47.400/02 estabelece prazos de validade para cada modalidade de licenciamento ambiental e condições para sua renovação; define: os empreendimentos sujeitos ao licenciamento ambiental devem comunicar a suspensão ou o encerramento das suas atividades, condicionando tais procedimentos à recuperação dos passivos ambientais e averbação no Registro de Imóveis das restrições ao uso porventura impostos pelo órgão ambiental.

Em 2003, a Secretaria do Estado do Meio Ambiente elaborou e apresentou ao Conselho Estadual de Meio Ambiente (Consema) um anteprojeto de lei sobre Proteção da Qualidade do Solo e Gerenciamento de Áreas Contaminadas ${ }^{6}$ mencionando, entre outras, a necessidade de "proteger a saúde humana, o meio ambiente e outros bens contra os efeitos negativos decorrentes de atividades poluidoras", "articulação dos órgãos públicos" e revitalização de ambientes urbanos degradados pela implementação de políticas públicas direcionadas à remediação de áreas contaminadas".

No anteprojeto ficava entendido que um dos meios de garantir o uso sustentável do solo era o incentivo à reutilização de áreas já remediadas (art. $2^{\circ}$ ) e que o plano diretor e a legislação de uso e ocupação do solo municipal eram os instrumentos para a implantação do sistema de proteção do solo e gerenciamento de áreas contaminadas ( $\left.\operatorname{art} .4^{\circ}\right)$.

$\mathrm{O}$ anteprojeto propunha que, após a remediação de uma área contaminada - cujos valores de referência de qualidade ambiental do solo seriam variáveis em decorrência do uso que seria dado a ela - fosse feita sua averbação no Registro de Imóveis, constando não só a remediação, mas também o uso permitido para o local, definido previamente pelo órgão ambiental e pela legislação de uso e ocupação do solo (art. 25). Qualquer novo uso ou

\footnotetext{
${ }^{6}$ Segundo informações do Sr. Malon Foguel, assessor parlamentar do deputado estadual Sebastião Almeida, este anteprojeto de lei foi aprovado pela Assembléia Legislativa.
} 
ocupação da propriedade estaria condicionado a uma nova avaliação de risco, tendo em conta o uso pretendido, além de averbação pelo Cartório de Registro de Imóveis (art. 26).

Os empreendimentos sujeitos ao licenciamento ambiental e potenciais geradores de contaminação ficariam obrigados a comunicar aos órgãos ambientais a suspensão ou o encerramento de suas atividades, devendo, para isso, ser elaborado um Plano de Desativação com descrição da situação ambiental da área e das estratégias a ser adotadas para recuperação de sua qualidade ambiental.

No que concerne aos instrumentos econômicos, foi proposta a criação do Fundo Estadual para Prevenção e Remediação de Áreas Contaminadas (Feprac), vinculado à Secretaria de Estado do Meio Ambiente, cujos recursos seriam "aplicados em operações financeiras destinadas a apoiar e a incentivar a execução de ações relacionadas com a remediação de áreas contaminadas" (art. 30).

Os recursos seriam provenientes de doações consignadas no orçamento do Estado, transferência do saldo de outros fundos, transferências da União, Estado e municípios, acordos de cooperação internacional, operações de crédito, doações, compensações ambientais, multas e licenças. Em casos de "perigos iminentes à saúde pública", o Estado poderia fazer uso destes recursos, a fundo perdido, para intervenção no problema.

Por fim, o anteprojeto indicava como necessário que os planos diretores municipais e a respectiva legislação de uso e ocupação do solo considerassem as áreas com potencial ou suspeita de contaminação e as áreas contaminadas (art. 39); que a aprovação de projetos de parcelamento do solo e de edificação deveria garantir o uso seguro das áreas com potencial ou suspeita de contaminação e das áreas contaminadas (art. 40); e que no licenciamento de empreendimentos em áreas que anteriormente abrigaram atividades com potencial de contaminação, deveria ser exigido o levantamento do passivo ambiental (art. 41). Nessa mesma direção o Município de São Paulo se adiantou, a partir de 2002, na regulação desses aspectos, em razão do grande número de áreas contaminadas ou potencialmente contaminadas presentes em seu território.

A descoberta e a ampla divulgação de inúmeros casos de contaminação do solo causaram preocupações não só à população, mas também aos empreendedores imobiliários. Para estes, o problema do conjunto residencial Barão de Mauá, no município de Mauá, implantado em área de antigo depósito de rejeitos industriais, foi emblemático e significou um alerta para a necessidade de adotar cuidados na avaliação do solo urbano e aquisição de lotes. (Valentim, 2005, p. 76). 
Diante deste caso foi elaborado, em 2003, um Guia para Avaliação do Potencial de Contaminação em Imóveis, no âmbito da Câmara Ambiental da Indústria da Construção (Pires, 2003). Esta é uma das seis Câmaras Ambientais da Atividade Produtiva instituídas a partir de 1995 para, em caráter consultivo, subsidiar as ações da Cetesb. Delas fazem parte representantes dos setores do comércio de derivados de petróleo, da construção civil, de minerais não-metálicos, dos químicos e petroquímicos, do têxtil e do sucroalcooleiro.

Assim, o Guia foi elaborado para

orientar empreendedores imobiliários, profissionais e empresas afins sobre as precauções e os procedimentos a serem adotados antes da realização de uma transação imobiliária, ou do início da implantação de um empreendimento, para verificar se a área a ser ocupada apresenta contaminação que coloque em risco a saúde pública e o meio ambiente (Pires, 2003, p. 11).

Esse documento propõe uma metodologia para identificar indícios de contaminação em imóveis que receberão novos empreendimentos, "notadamente em áreas que foram aterradas ou que foram ocupadas por indústrias" (Pires, 2003, p. 25).

Dessa forma, adquire significativa importância o que se fez - ou o que se deixou de fazer - na cidade para efeito de renovação ou expansão urbana. Não é por outro motivo que a primeira das etapas básicas sugeridas pelo referido Guia para avaliação ambiental de um imóvel seja o levantamento do histórico de sua ocupação e da vizinhança. Tal providência visa evitar graves problemas, representados por casos como o Barão de Mauá ${ }^{7}$ e Vila Carioca $^{8}$, que deixaram evidente que os agentes envolvidos na construção civil deveriam agir com precaução antes de iniciar novos empreendimentos.

Reconhecendo que não existe ainda no Brasil uma legislação específica para as questões que envolvam áreas contaminadas, o Guia dá destaque à regulação do uso do solo como instrumento relevante para o controle do problema, fazendo menção, a título de exemplo, à legislação do Município de São Paulo.

Desta forma, áreas contaminadas representam problemas múltiplos: um risco à saúde humana e dos ecossistemas; um risco à segurança pública; restrições ao desenvolvimento urbano; redução do valor dos imóveis (SÁNCHEZ, 2001). Assim, o próximo capítulo tratará das medidas judiciais que visam aplicação destas leis de proteção do solo, bem como punir os responsáveis pela contaminação do solo entre outros.

\footnotetext{
${ }^{7}$ Um condomínio de edifícios residenciais construídos sobre uma antiga área de disposição de diversos resíduos industriais.

${ }^{8}$ Residências localizadas em terrenos vizinhos a uma base de armazenamento de combustíveis, pertencente à Shell, que utilizavam água subterrânea contaminada.
} 


\section{Capítulo III - Medidas Judiciais Aplicáveis para Garantir o direito à Saúde}

Sendo o meio ambiente um bem de uso comum do povo, insuscetivel de apropriação por quem quer que seja, não bastava, para a sua eficaz tutela, apenas se erigir cada cidadão num fiscal da natureza, com poderes para provocar a iniciativa do Ministério Público, mas era de rigor assegurar-se o efetivo acesso ao Judiciário dos grupos sociais intermediários e do próprio cidadão em sua defesa. (Milaré, 2007, p. 1.073)

A sociedade vem passando por profundas transformações nos últimos anos, sendo que a realidade socioeconômica modificou-se com rapidez e o século XX se caracterizou pelo desenvolvimento incessante das economias de massa. Por conseqüência, os sistemas de produção desenvolveram-se, com repercussão evidente na oferta de bens, tudo de forma acelerada e sem preocupação com a degradação ambiental.

Infelizmente, nos tempos atuais é comum nos depararmos com alguma questão ambiental e existe uma preocupação sobre o como lidar adequadamente não apenas com os efeitos dos riscos, mas com a própria existência destes. Essa transformação por que passou a configuração da sociedade - e que assume o perfil do que Beck considera uma sociedade mundial do risco ou uma sociedade do risco global (Beck, 2002) - foi tratada no capítulo anterior.

É evidente que a conservação e proteção ambiental são relevantes e essenciais para a vida de todos; o mesmo vale para sua degradação e maus tratos, uma vez que atingirá e acarretará prejuízos diretos à vida humana, ou seja, será extremamente prejudicial a todos sem distinção.

Assim, neste capítulo se procurará apresentar as medidas judiciais possíveis para garantir a tutela de direitos coletivos, envolvendo questões ambientais, dando ênfase maior, no entanto, à Ação Civil Pública - ACP, pois o próximo capítulo analisará a tramitação de uma ação judicial, relacionada com a contaminação de solo no bairro da Vila Carioca, região sul da cidade. 


\subsection{Ação Civil Pública Ambiental}

A Lei 6.938/81, que definiu a política nacional de meio ambiente, estabeleceu, em seu art. $14, \S 1^{\circ}$, a possibilidade de ação civil pública ambiental ao conceder legitimação ao Ministério Público para promover ação por responsabilidade civil contra o poluidor por danos causados ao meio ambiente.

Assim, a ação civil pública ambiental tem sua origem nessa Lei, cujo caráter é de direito material, e somente teve sua instrumentação efetiva com a Lei 7.347/85 (Lei da Ação Civil Pública - LACP), que trata de aspectos processuais. Todavia, com a edição do Código de Defesa do Consumidor (CDC - Lei 8.078/90), o campo de incidência da Lei da Ação Civil Pública foi ampliado, por meio de dispositivos que possibilitaram a defesa de outros interesses difusos (art. 110 da Lei 8.078/90), bem como dos interesses individuais homogêneos (arts. 91 a 100 do CDC).

A diferença principal entre interesses difusos e coletivos está na titularidade: interesses difusos estariam relacionados a pessoas indeterminadas (art. 81, I do CDC); e nos interesses coletivos seriam os de indivíduos integrantes de grupo, categoria ou classe (art. 81, III do Código de Defesa do Consumidor), ou seja, não pode ser usada para amparar direitos individuais puros.

A CF garantiu o direito previsto na LACP assegurando o acesso ao Poder Judiciário para apreciação de ameaça a direito ou lesão a interesses difusos e coletivos. Para Marcelo Abelha Rodrigues, a "ação civil pública consagrou-se como o mais importante remédio para tornar concreta a defesa desses interesses" (Rodrigues, 2005). Ele acrescenta que este tipo de ação é atualmente mais utilizado na área ambiental devido à vocação natural da lei tutelar de direitos transindividuais.

Milaré refere-se à natureza jurídica da ACP conforme entendimento de Álvaro Luiz Valery Mirra, em que pese ser especialíssima, por não se tratar de direito subjetivo, e sim "direito atribuído a órgãos públicos e privados para a tutela de interesses não individuais strictu senso" - e, no entanto vitais a sadia qualidade de vida da comunidade (Milaré, 2001, p. 164).

Dessa maneira, a ACP é um dos instrumentos constitucionais por meio dos quais o Ministério Público e outros legitimados coletivos dispostos em lei (art. $5^{\circ}$ da Lei 7.347/85 e art. 82 da Lei 8.078/90) podem pleitear a tutela jurisdicional de quaisquer direitos coletivos lato sensu (direitos difusos, direitos coletivos em sentido estrito ou individuais homogêneos). Em outros termos, objetivam a proteção do patrimônio público, do meio ambiente, dos 
consumidores e da ordem econômica, tendo por fim a condenação dos responsáveis à reparação do interesse lesado.

No art. $5^{\circ}$ da LACP prevê-se o rol dos legitimados para propor ação: o Ministério Público; a Defensoria Pública (incluída pela Lei 11.448/2007); a União, os Estados, o Distrito Federal e os municípios; autarquias, empresas públicas, fundações ou sociedades de economia mista; associações que, concomitantemente, estejam constituídas há pelo menos um ano nos termos da lei civil e incluam entre suas finalidades institucionais a proteção ao meio ambiente, ao consumidor, à ordem econômica, à livre concorrência ou ao patrimônio artístico, estético, histórico, turístico e paisagístico - todos têm legitimidade para propor a ação.

A ACP terá por objeto a condenação em dinheiro ou o cumprimento de obrigação de fazer ou não fazer algo.

A sentença fará coisa julgada erga omnes, ou seja, os efeitos serão para todos (art. 16 da Lei 7.347/85). Assim, a sentença de procedência do pedido, proferida na ação coletiva com trânsito em julgado, servirá para reparação de dano ambiental sofrido individual ou coletivamente, após regular liquidação do julgado.

Se a ação for julgada improcedente por insuficiência de provas, no entanto, qualquer legitimado poderá intentar outra ação com idêntico fundamento, mas com novas provas.

Na sequiência, vislumbra-se a dificuldade do estabelecimento do valor indenizatório, que restará na dependência da cabal demonstração do dimensionamento real do dano. $\mathrm{Na}$ realidade, uma das questões mais intrincadas nesse campo, para o Judiciário, reside, exatamente, na quantificação ou valoração do dano ao meio ambiente.

Outras particularidades da ACP devem, todavia, ser analisadas. Então, vejamos.

\subsubsection{Antecipação da Tutela}

O sistema de jurisdição civil coletiva prevê a tutela antecipada, criando mais um instrumento de efetivação do direito material ameaçado ou violado, sendo que o art. 12 da Lei 7.347/85 (ACP) dispõe a regra geral para a concessão da liminar antecipatória do direito e exige o preenchimento dos requisitos do periculum in mora e do fumus boni iuris.

A nossa legislação permite que o juiz adiante a tutela pleiteada antecipadamente, em caráter provisório, desde que estejam presentes os requisitos: a) se for relevante o fundamento da demanda; b) se houver justificado receio de ineficácia do provimento final. 
Por sua vez, o art. $84, \S 3^{\circ}$ da Lei 8.078/90 (CDC) também prevê a liminar antecipatória do mérito, sendo relevante o fundamento da demanda e havendo justificado receio de ineficácia do provimento final.

O art. $273^{9}$ do Código de Processo Civil (CPC) prevê a tutela antecipatória de forma genérica e estabelece os requisitos para a jurisdição civil individual, enquanto o seu art. 461, $\S$ $3^{\circ}$, regula o instituto nas ações de obrigação de fazer e não fazer. A tutela antecipatória pode ser concedida em causas envolvendo direitos patrimoniais ou não patrimoniais.

Será possível, todavia, a concessão de liminar antecipatória na esfera da jurisdição coletiva com base no art. 273 do CPC, desde que consubstanciada na hipótese do inciso II, porquanto o inciso I deste artigo reclama grau de cognição para o convencimento do juiz mais vertical que o previsto nos arts. 12 da Lei 7.347/85 (ACP) e art. 84, $\S 3^{\circ}$ da Lei 8.078/90 (provas inequívocas para que se convença da verossimilhança da alegação).

Dessa forma, ensina Edis Milaré, para o êxito da medida, deverá o juiz convencer-se: a) da verossimilhança da alegação; b) de fundado receio de dano irreparável ou de difícil reparação; c) da caracterização de abuso de direito de defesa ou de propósito protelatório do réu; e d) da reversibilidade da medida (Milaré, 2007, p. 1.041).

É importante esclarecer que, ao conceder a tutela antecipatória, por estarem presentes os pressupostos, deverá o juiz motivar a decisão, indicando o porquê da verossimilhança do dano irreparável ou de difícil reparação ${ }^{10}$.

Nelson e Rosa Nery instruem que "a tutela antecipada dos efeitos da sentença de mérito não é tutela cautelar, porque não se limita a assegurar o resultado prático do processo, nem a assegurar a viabilidade da realização do direito afirmado pelo autor, mas tem por objetivo conceder, de forma antecipada, o próprio provimento jurisdicional pleiteado ou seus efeitos". E concluem:

Além de ser medida distinta das cautelares, a tutela antecipatória também não se confunde com o julgamento antecipado da lide (CPC 330). Neste, o juiz julga o próprio mérito da causa, de forma definitiva, proferindo sentença de extinção do processo com a apreciação da lide (CPC 269). Nos casos de CPC 273 o juiz antecipa

\footnotetext{
9 “Art. 273. O juiz poderá, a requerimento da parte, antecipar, total ou parcialmente, os efeitos da tutela pretendida no pedido inicial, desde que, existindo prova inequívoca, se convença da verossimilhança da alegação e:

I - haja fundado receio de dano irreparável ou de difícil reparação; ou

II - fique caracterizado o abuso de direito de defesa ou o manifesto propósito protelatório do réu.

$\S 1^{\circ} \mathrm{Na}$ decisão que antecipar a tutela, o juiz indicará, de modo claro e preciso, as razões do seu convencimento. $\S 2^{\circ}$ Não se concederá a antecipação da tutela quando houver perigo de irreversibilidade do provimento antecipado. (...)

$\S 5^{\circ}$ concedida ou não a antecipação da tutela quando, prosseguirá o processo até final julgamento"

${ }^{10}$ A necessidade de motivação das decisões do Judiciário vem também expressa no art. 93, IX e X, da CF.
} 
os efeitos da sentença de mérito, por meio de decisão interlocutória, provisória, prosseguindo-se no processo. No julgamento antecipado da lide há sentença de mérito, impugnável por apelação e sujeita à coisa julgada material; na tutela concedida antecipadamente há decisão interlocutória, impugnável por agravo e não está sujeita à coisa julgada material (Nery Jr.; Nery, 2007, pp. 523-4).

No caso de indeferimento de liminar pelo juízo de primeira instância, é admissível que o autor da ACP obtenha, no Tribunal, a antecipação da tutela pretendida, por via recursal.

\subsubsection{Medida Liminar}

No nosso ordenamento jurídico pode ser veiculada, na petição inicial da ação ambiental, solicitação de medida liminar, inclusive "inaudita altera parte" (art. 12, caput, LACP) - isto apesar de, no art. $1^{\circ}$, referir-se expressamente à responsabilidade por danos. Também contém disposições apropriadas à tutela preventiva (arts. $4^{\circ}, 5^{\circ}$ e 12 ), tudo em consonância com o princípio constitucional de que nenhuma lesão ou ameaça a direito será excluída da apreciação do Poder Judiciário (CF, art. 5º XXXV).

Assim, independentemente do ajuizamento de ação cautelar, poderá ser proposta demanda objetivando a proteção do meio ambiente, cumulada com pedido de liminar, que será concedida com ou sem justificativa prévia, uma vez presentes os requisitos do fumus boni iuris e do periculum in mora.

Sobre este assunto, pertinentes as ponderações de Antonio Raphael Silva Salvador, que assevera:

Possíveis as liminares, temos a certeza de que os nossos juízes irão delas cuidar com a maior atenção, compreendendo que sua concessão deve ser feita quando evidente o periculum in mora, mas o perigo real, que não pode ser maior do que o perigo resultante de liminares que suspendam atuações regulares do Poder Público, de liminares que tragam danos maiores do que aqueles que se pretende evitar (Salvador, 1997, p. 19).

No que tange à concessão de liminares contra atos do Poder Público, cumpre destacar o art. $2^{\circ}$ da Lei 8.437/92, que exige a audiência prévia do representante judicial da pessoa jurídica-ré, mediante manifestação, no prazo de 72 horas. Naturalmente, semelhante procedimento somente será observado se não sujeitar o bem ambiental cuja tutela é almejada a situação de irreparabilidade.

Assim, consoante exemplifica José Carlos Barbosa Moreira, não se pode pensar, apenas, em ressarcimento de dano já ocorrido, pois 
esses interesses, entre outras características, têm a de que, as mais das vezes, precisam ser protegidos antes de consumada a lesão. Isso fica muito nítido no que tange ao meio ambiente. (...) destruída a rocha que embelezava a paisagem, o dano é irreparável e não há como pretender substituir aquilo que deixou de existir por uma compensação pecuniária (Moreira, 1993, p. 186).

Cabe observar que as medidas cautelares são muito utilizadas, até mesmo como regra, para compelir o causador de dano ambiental ao cumprimento da obrigação de não fazer.

Esclarecedora é a manifestação de Édis Milaré, ao destacar que,

no Direito Ambiental, diferentemente do que se dá com outras matérias, vigoram dois princípios que modificam, profundamente, as bases e a manifestação do poder de cautela do juiz: a) o princípio da prevalência do meio ambiente (da vida) e b) o princípio da precaução, algo mais que o princípio da prevenção, já tradicional no nosso Direito. Tutela jurisdicional que chega quando o dano ambiental já foi causado perde, no plano da garantia dos valores constitucionalmente assegurados, muito, quando não a totalidade de sua relevância ou função social (Milaré, 1995, p. 26).

\subsubsection{Inquérito Civil}

O inquérito civil está previsto no art. $8^{\circ}, \S 1^{\circ}$ da Lei $7.347 / 85$ e consagrado no art. 129 , III, da CF. É um procedimento administrativo investigatório com caráter pré-processual, que se realiza extrajudicialmente, e quando está a cargo do Ministério Público, se destina a colher elementos para eventual propositura da ação civil pública ou coletiva. É uma investigação que objetiva colher elementos de convicção para promoção de ACP, ou seja, a finalidade dessa apuração é determinar a materialidade e a autoria dessas lesões. Não é obrigatório, podendo ser dispensado se o promotor de Justiça já tiver em mãos os elementos para propor a ação principal, para a defesa de interesses transindividuais ou defesa do patrimônio público e social.

O inquérito civil é público, ou seja, pode ser acompanhado e examinado por qualquer pessoa. Exceções: quando a publicidade for prejudicial à própria investigação ou quando o sigilo for imprescindível à segurança da sociedade e do Estado (art. $5^{\circ}$ XXXIII, da CF).

Como visto, a União, os Estados, os municípios, as autarquias, as empresas públicas, as sociedades de economia mista, as fundações ou as associações civis podem propor a ação civil pública ou coletiva; antes de propô-la, é natural que recolham elementos de convicção necessários, e farão isso em procedimentos quaisquer, pois o inquérito civil só pode ser instaurado pelo Ministério Público. 
$\mathrm{Na}$ falta de elementos para propositura da ação o promotor de Justiça pode efetuar o arquivamento sem intervenção judicial, devendo apenas, no prazo de três dias, encaminhar os autos à apreciação do Conselho Superior do Ministério Público, para reexame obrigatório do caso. Nada impede a propositura de ação por parte dos demais legitimados.

\subsubsection{Prova pericial}

A prova pericial é um dos maiores problemas existentes para a coleta de provas, tanto no processo civil tradicional (individual) quanto no que tange à tutela jurisdicional coletiva, que visa à proteção de um número maior de titulares dos bens lesados ou ameaçados de lesão, associado ao fato de que a perícia geralmente exige especialidades e equipe multidisciplinar de peritos.

O Código de Processo Civil dispõe, em seu art. 420, que "a prova pericial consiste em exame, vistoria ou avaliação". E, no artigo seguinte: "o juiz nomeará o perito, fixando de imediato o prazo para entrega do laudo".

Observa-se que o nosso estatuto processual não impõe ao magistrado que, ao nomear o perito para a realização da prova técnica, observe sua especialidade em relação aos fatos a ser apurados.

Espera-se, todavia, bom senso dos magistrados no momento da nomeação, para que analisem as habilidades técnicas, bem como as peculiaridades do objeto de perícia. $\mathrm{Na}$ realidade, porém, ainda há muita defasagem entre os casos existentes e a especialidade dos profissionais, porque envolvem uma equipe multidisciplinar. Verifica-se, na prática, a nomeação de engenheiros civis para quase todas as perícias a realizar na área ambiental, quando é sabido que estes não possuem habilitação profissional e legal para se manifestar sobre a matéria.

O inciso I do art. 424 do CPC permite, entretanto, a substituição do perito quando este "carecer de conhecimento técnico ou científico". Mas os juízes têm decidido que cabe ao próprio expert declarar que não possui o conhecimento necessário para elaboração do laudo, quando for o caso, ficando as partes nas mãos daquele ou tendo de recorrer da decisão que nomeou pessoa inabilitada. Ressalte-se que nossos Tribunais ainda não se sensibilizaram com a questão.

O problema é importante, uma vez que em uma perícia para ACP ambiental vários problemas devem ser analisados: poluição, agentes químicos, contaminação, reflexos na flora 
ou fauna, entre outros que, com certeza, envolvem mais de um ramo das ciências químicas, físicas ou biológicas, porém será realizada apenas um expert, sendo que ao final o laudo pericial vai embasar uma decisão judicial.

Para Vladimir Passos de Freitas,

com respeito à perícia cumpre mencionar, ainda, que ela deve, necessariamente, ser feita por especialista da área. Assim, não tem cabimento, por exemplo, delegar a um engenheiro civil a estimativa de dano produzido pelo desmatamento de área de preservação permanente. É tarefa para um engenheiro florestal ou agrônomo (Freitas, 2002, pp. 187-8).

Filippe Augusto Vieira de Andrade e Maria Aparecida Alves Villar Gulin, após enfatizar a importância e a complexidade das perícias ambientais, destacam que "nas ações ou medidas judiciais ambientais, sendo necessária produção de prova pericial, deverá ser verificado se esta, pela sua complexidade, reclama conhecimento técnico ou científico multiprofissional”, e que, se positiva esta situação, “deve o juiz nomear tantos peritos quanto sejam necessários para uma abordagem holística, respeitada a formação técnico-científica de cada um” (apud Freitas, 1998, pp. 100-1).

Outro aspecto polêmico que envolve a perícia ambiental diz respeito ao preço, conforme destaca Carlos Alberto de Salles:

ações em matéria ambiental, em especial, envolvem custos elevados. O meio ambiente está relacionado a problemas de elevada complexidade, cuja formalização em um processo judicial envolve elevado grau de sofisticação. A defesa judicial do meio ambiente implica questões 1) de conhecimento técnico e científico, 2) de informação imperfeita, 3) de risco substancial, 4) de partes numerosas, 5) de múltiplas possíveis alternativas, 6) de pluralidade de centros de decisão e 7) de oportunidades para efeitos de natureza distributiva (Salles, 1998, p. 127).

A realização da prova pericial ambiental é muito importante ao entendimento e mensuração de determinado dano, mas, às vezes, não satisfaz seu real objetivo, implicando um completo desprezo pelos princípios constitucionais. Logo, não pode perder seu caráter científico e técnico.

É importante, ainda, registrar que estudiosos vêm tentando fixar regras para as estimativas de danos ambientais, merecendo destaque o trabalho da professora Helita Barreira Custódio, que aponta princípios constitucionais e normas jurídicas a ser observados quando das avaliações:

Diante da complexidade e da conseqüente dificuldade para avaliação de custos ambientais em cada ação jurídica de lesão ao meio ambiente, com específica matéria de fato, para melhor compreensão 
sobre os valores básicos integrantes e suscetíveis de ressarcimento, tornaram-se indispensáveis breves observações sobre os recursos naturais $e$ os bens culturais integrantes do meio ambiente, cuja degradação impõe, pelas expressas normas constitucionais, legais e regulamentares vigentes, a reparação das perdas e dos danos, além dos lucros cessantes, de acordo com as particularidades de cada caso concreto (Custódio, 1990, p. 16).

\subsubsection{Termo de Compromisso de Ajustamento de Conduta (TAC)}

O compromisso de ajustamento de conduta está previsto no $\S 6^{\circ}$ do art. $5^{\circ}$ da Lei 7.347/85. Consagra figura peculiar de transação, na medida em que pode prevenir a propositura de uma ACP, quando é realizado na fase do inquérito civil, ou pôr fim à ação em andamento. Estão legitimados a celebrar o acordo somente os órgãos públicos, ou seja, o Ministério Público e as pessoas políticas de direito público interno.

Trata-se de um instrumento legal destinado a colher, do causador do dano, um título executivo extrajudicial de obrigação de fazer, mediante o qual o compromitente assume o dever de adequar sua conduta às exigências da lei, sob pena de sanções fixadas no próprio termo.

Paulo Affonso Leme Machado, ao abordar este tema, faz um interessante estudo do significado das palavras: "Ajustar" tem diversas acepções, mas considera "convencionar", "combinar", "estipular". Explica que o termo "ajustamento", se tivesse sido empregado pela lei de forma isolada, poderia conduzir à interpretação de que o ajustamento entre os órgãos públicos e os interessados seria um contrato ou convenção negociada conforme a vontade de ambas as partes. Contudo, atenta que a lei une dois termos: "ajustamento" e "obrigações legais" (Machado, 2007).

O autor explica que "ajustamento" não significa transigência no cumprimento das obrigações legais. E alerta que o Ministério Público não pode fazer concessões diante de "interesses sociais e individuais indisponíveis" (art. 127, caput, da CF). "Dispor ou renunciar às obrigações legais é inadmissível por parte do Ministério Público” (Machado, 2007, p. 374).

Em conformidade, o Conselho Superior do Ministério Público se manifestou: "É vedada a dispensa, total ou parcial, das obrigações reclamadas para a efetiva satisfação do interesse lesado, devendo a convenção com o responsável restringir-se às condições de 
cumprimento das obrigações (modo, tempo, lugar etc.), bem como deverão ser estipuladas cominações para a hipótese de inadimplemento"11.

Para Hugo Nigro Mazzilli, não pode o compromisso de ajustamento conter cláusulas que exorbitem seu objeto ou seus limites, mormente se tendentes à dispensa de requisitos legais. Exemplifica que o TAC não pode ser usado para permitir o prosseguimento de obras em loteamentos clandestinos ou irregulares ou para dispensar, no todo ou em parte, o causador do dano do dever de ressarcimento pecuniário, entre outros. E adverte que o compromisso presta-se a exigir o cumprimento das regras legais (obrigações de conduta), ou seja, nele "devem ser fixados os prazos a partir dos quais poderão ser executadas as cominações ajustadas, independentemente de ação de conhecimento (p. ex., a instalação de filtros em chaminés industriais, o plantio de espécies vegetais, a realização de obras necessárias ou úteis a um loteamento etc.)” (Mazzilli, 2003, p. 573).

A transação judicial tanto pode dar-se no processo como em procedimento avulso levado à homologação judicial. Deve observar todos os requisitos de validade exigidos do ajuste extrajudicial:

1) necessidade da integral reparação do dano, em razão da natureza indisponível do direito violado;

2) indispensabilidade de cabal esclarecimento dos fatos, de modo a ser possível a identificação das obrigações a estipular, já que desfrutará de eficácia de título executivo judicial;

3) obrigatoriedade da estipulação de cominações para a hipótese de inadimplemento;

4) anuência do Ministério Público, quando não seja o autor.

Nesse contexto, Daniel Roberto Fink adverte: “o objeto a ser negociado não é o meio ambiente, mas as condições de modo, tempo e lugar do cumprimento da obrigação de recuperar integralmente o meio ambiente" (Fink, 2001, p. 121).

Assim, o TAC tem a eficácia de um título executivo extrajudicial, pois propicia a imediata execução judicial das obrigações pactuadas, permitindo adaptar às exigências legais a conduta daqueles que causaram danos ao meio ambiente.

A lei não exige homologação judicial para o TAC, porém, se a transação versar sobre interesses difusos, coletivos ou individuais homogêneos que estejam sendo objeto de discussão em juízo, neste caso deverá haver a homologação judicial para o ajuste produzir o efeito de extinguir o processo.

\footnotetext{
${ }^{11}$ Ato 9/92 da Procuradoria-Geral da Justiça, Conselho Superior do Ministério Público e da Corregedoria-Geral do Ministério Público do Estado de São Paulo, publicado no DOE 23.7.1992.
} 
Observa-se que o produto da condenação em dinheiro não beneficia o autor da ação, mas é recolhido a um fundo destinado à restituição dos bens lesados (art. 13 LAC).

Na condenação da obrigação de fazer ou não fazer, o juiz determinará o cumprimento da prestação da atividade devida ou cessação da atividade nociva, sob pena de execução específica ou de cominação de multa diária.

O Promotor de Justiça Daniel Roberto Fink conclui:

Há vantagens do ajustamento de conduta em relação ao processo judicial representado pela ação civil pública. Portanto, antes de se lançar mão de tão desgastante, caro e difícil solução para o conflito ambiental, deve-se buscar a via da negociação, por meio da qual todos encontrarão seus lugares e ao final do processo sairão muito mais fortalecidos do que se fossem obrigados a obedecer um comando frio e inexorável de uma sentença (Fink, 2001, p. 139).

\subsubsection{O Ministério Público}

O Ministério Público vem exercendo um importante papel na defesa do meio ambiente, do patrimônio cultural, do patrimônio público, dos interesses coletivos em geral. Dessa forma, além do ajuizamento de ACPs e de outras ações para a defesa dos interesses difusos, o MP possui atribuições para realizar o Inquérito Civil Público. Quanto aos TACs, celebrados na fase administrativa, verifica-se que obtêm resultado positivo mais rápido e eficiente do que os que poderiam ser obtidos através do uso das vias judiciais.

$\mathrm{O}$ art. 127 da CF dispõe que o "Ministério Público é instituição permanente essencial à função jurisdicional do Estado, incumbindo-lhe a defesa da ordem jurídica, do regime democrático e dos interesses sociais e individuais indisponíveis" e estabelecendo a área de atuação desta instituição, tanto no âmbito extrajudicial quanto judicial.

Em se tratando de ACP, convém observar que o Ministério Público tem o dever legal de agir, sendo necessário o ajuizamento de ação quando se deparar com a incidência de hipótese que enseje a utilização da medida cabível para defesa de interesses difusos.

Essa obrigatoriedade está, contudo, adstrita a uma análise por parte do membro ministerial de cada caso, pois este poderá dispensar a medida quando não achar cabível para a solução do problema, podendo recorrer previamente a meios extrajudiciais, como o ajustamento de conduta, ou até mesmo entender não haver dano ao interesse metaindividual, promovendo o arquivamento do Inquérito Civil, do Procedimento Preparatório de Inquérito Civil ou das peças de informação. Mas estes estarão sempre, ex officio, submetidos à 
apreciação pelo Conselho Superior do Ministério Público para confirmação ${ }^{12}$, tanto que, se o órgão colegiado não entender da mesma forma, designará outro profissional para que ajuíze a ACP.

“Todavia, se o Ministério Público não tem discricionariedade para agir ou deixar de agir quando identifica a hipótese de atuação, ao contrário, tem liberdade para apreciar se ocorre hipótese em que sua ação se torna obrigatória" (Mazzilli, 2001, p. 78). Dessa forma, depois de provocada a jurisdição, a ação perde esse seu caráter disponível e torna-se indisponível, nos moldes da ação penal pública, não podendo o Ministério Público dela desistir, salvo nas hipóteses de acordo (pode homologar acordos judiciais que funcionaram como título executivo, dispensando a fase judicial do conhecimento.

A contrario sensu da ação penal pública incondicionada, o arquivamento das peças de informação não desautoriza qualquer um dos co-legitimados a intentar por si a ação em juízo. Estes podem se valer dos elementos probatórios carreados e promover a ação, com o Ministério Público intervindo como custus legis. Assim, observa Hugo Nigro Mazzilli:

Não é inconstitucional o sistema da LACP, ao permitir ao Ministério Público arquive o inquérito civil, pois essa decisão ministerial não impede que o Judiciário conheça da lesão de direito. A decisão de arquivamento do inquérito civil ou das peças de informação não obsta a que qualquer co-legitimado proponha a ação civil pública ou coletiva acaso cabível; e o próprio lesado sempre poderá propor a ação necessária à defesa de seu interesse individual (Mazzilli, 2001, p. 81).

O Ministério Público, não sendo o titular da ação, terá a obrigação de intervir no processo, atuando como fiscal da lei. Essa atuação ministerial é importante na verificação da legalidade procedimental e material, pautando-se no atuar pelo e para o direito. Ele opinará nos atos do processo, manifestando-se nos momentos oportunos e ofertando parecer ao final.

Diante dos diversos problemas socioambientais, o Ministério Público do Estado de São Paulo tem um papel importante e de destaque na defesa dos interesses coletivos. $\mathrm{O}$ destaque se deve às inúmeras ACPs ajuizadas e outras ações voltadas à defesa dos chamados interesses difusos, como TACs, celebrados no curso de procedimentos administrativos, que

\footnotetext{
12 “Se o órgão do Ministério Público, esgotadas todas as diligências, convencer-se da inexistência de fundamento para a propositura da ação civil, promoverá o arquivamento dos autos do inquérito civil ou das peças informativas, fazendo-o fundamentadamente.

$\$ \mathbf{1}^{\mathbf{0}}$ - Os autos do inquérito civil ou das peças de informação arquivadas serão remetidos, sob pena de se incorrer em falta grave, no prazo de 3 (três) dias, ao Conselho Superior do Ministério Público.

$\$ \mathbf{2}^{\mathbf{0}}$ - Até que, em sessão do Conselho Superior do Ministério Público, seja homologada ou rejeitada a promoção de arquivamento, poderão as associações legitimadas apresentar razões escritas ou documentos, que serão juntados aos autos do inquérito ou anexados às peças de informação.

$\S \mathbf{3}^{\mathbf{o}}$ - A promoção de arquivamento será submetida a exame e deliberação do Conselho Superior do Ministério Público, conforme dispuser o seu Regimento.

$\S 4^{\mathbf{0}}$ - Deixando o Conselho Superior de homologar a promoção de arquivamento, designará, desde logo, outro órgão do Ministério Público para o ajuizamento da ação.”
} 
obtêm resultado positivo mais rápido e eficiente do que os que poderiam ser obtidos por uso das vias judiciais.

Observa-se, ainda, que o MP passa a assumir um novo compromisso, de aspecto social e em razão de suas funções constitucionais e legais, ou seja, o relevante encargo de atendimento ao público, lembrado por Hugo Mazzilli como "um dos canais mais adequados para o zelo pelo efetivo respeito dos Poderes Públicos e dos serviços de relevância pública aos direitos assegurados na Constituição (Constituição da República, art. 129, II)” (Alonso Jr., 2006, p. 167).

O órgão busca assegurar os direitos das massas, sobretudo das excluídas, demonstrando a importância da instituição na viabilização do amplo acesso ao Poder Judiciário (Art. 5 $\mathrm{XXXV}$, da CF). Como assevera Antonio Augusto Mello de Camargo Ferraz,

a definição do perfil do Ministério Público brasileiro está em que a nossa sociedade civil, a nossa população, infelizmente ainda tem pouca consciência de seus direitos políticos, sociais e mesmo individuais. Por outro lado, são ainda incipientes os mecanismos (como os Juizados Especiais de Pequenas Causas) tendentes a tornar mais fácil e menos oneroso o acesso à Justiça. Assim, como consequiência, verifica-se na prática que a sociedade civil tem dificuldade de reagir, ela própria e diretamente, diante de violações a interesses públicos, sociais, difusos e coletivos (apud Alonso Jr., 2006, p. 169).

Diante desse contexto nasce outro dever, sem que isso represente um negligenciar as outras áreas tradicionais de atuação, "que é a incumbência de rearticular forças, métodos e metas, desenvolvendo-se a partir desta nova realidade social para obter resultados práticos justificadores da confiança depositada pelo Constituinte e aproximando a legalidade, cada vez mais, da legitimidade popular" (Alonso Jr., 2006, p. 171).

O promotor de Justiça do Meio Ambiente Hamilton Alonso Jr. destaca em sua obra diversos trabalhos e teses que demonstram este atual perfil do MP, que se atenta mais aos anseios sociais:

Os últimos Congressos Nacionais do Ministério Público, realizados, respectivamente, em Curitiba/PR e Recife/PE, Gramado/RS e Belo Horizonte/MG, contaram com inúmeras iniciativas nesse sentido, bastando examinar o subtema II na área cível do Congresso de Pernambuco: "A contribuição do Ministério Público para a efetivação dos direitos sociais e fundamentais do cidadão", e o número de teses apresentadas, que totalizaram 42 (...). Neste mesmo evento, aliás, 36 trabalhos foram apresentados no subtema III: "Política institucional e administrativa: reflexão crítica na busca do aprimoramento", o que denota, uma vez mais, a busca incessante de aprimoramento (Alonso Jr., 2006, p. 171). 
O autor relata várias situações que fazem crer que a instituição está cada vez mais atenta aos problemas sociais na implementação dos direitos fundamentais. Por exemplo, a Revista da Conamp (Associação Nacional dos Membros do Ministério Público) noticia projeto lançado pelo MP do Estado do Rio Grande do Norte denominado "Aprendendo a ser cidadão com o Ministério Público", no qual promotores de Justiça iniciam o aprendizado das crianças em sala de aula do ensino básico em áreas como a defesa da cidadania, saúde pública, direitos de deficientes físicos e meio ambiente, inclusive com distribuição de cartilhas de orientação próprias para o público infantil.

No Estado de São Paulo, a Promotoria de Justiça do Meio Ambiente da Capital, não se conformando em apenas receber representações e reclamações ${ }^{13}$ sobre problemas ambientais pontuais e isolados, decidiu-se pela instauração de procedimentos investigatórios gerais, denominados protocolados gerais, que possibilitariam um diagnóstico geral e detalhado sobre os temas mais delicados no campo ambiental.

Em entrevista concedida à Revista da Associação Paulista do Ministério Público $\mathrm{n}^{\circ}$ 9, de agosto de 1997, os promotores de Justiça integrantes da Promotoria de Justiça do Meio Ambiente ${ }^{14}$ definiram o protocolado geral como

um procedimento investigatório a respeito de situaçães globais que
nunca vimos na legislação. Ele funciona de forma simples: um dos
colegas preside - por escolha interna - a pesquisa de um assunto
(mineração, por exemplo) sob o ponto de vista geral. Os fatos
concretos de interesse que são apurados são distribuídos na
Promotoria entre todos os colegas, que realizam um trabalho
individual de investigação e até de responsabilização das empresas
poluentes. A intenção é a obtenção de um diagnóstico geral sobre os
temas ambientais, que possibilite uma atuação singular mais eficiente
por parte da Promotoria (Alonso Jr., 2006, p. 184).

A Promotoria começou a instaurar os protocolados gerais, sendo que os interesses locais ditaram a escolha do tema merecedor de maior atenção, como problemas na área de proteção dos mananciais, mineração, poluição sonora e atmosférica, resíduos, patrimônio cultural, coleta e tratamento de esgoto, vegetação, parques públicos. Após a instauração do protocolado geral, passou-se a diagnosticar a situação de cada uma destas questões, buscandose junto aos órgãos públicos os levantamentos técnicos e estatísticos, as normas específicas, elaboração de laudos, estudo de políticas públicas em formação e em execução, dentre outras providências.

13 O Ministério Público do Estado de São Paulo recebe reclamações e denúncias por e-mail (<http://www.mp.sp.gov.br).

14 À época da criação e execução dos protocolados gerais, a Promotoria de Justiça era composta pelos Drs. Daniel Roberto Fink, Hamilton Alonso Jr., Lídia Helena Ferreira da Costa Passos, Marcelo Dawalibi e Tiago Cintra Zarif. 
Dentro dessa nova estratégia de atuação, vários casos concretos foram merecedores de atuação do $\mathrm{MP}^{15}$ em separado, além de outras utilidades expostas pelo promotor Hamilton Alonso Jr.:

(a) fonte de informação e instrução dos casos individuais (obtenção da legislação pertinente, levantamento já feito pelos órgãos públicos, necessidades coletivas etc.); (b) meio de participação popular, com acolhimento de representações e reclamos generalizados (cartas ao leitor, em jornais, editoriais, e-mails, declarações tomadas por termo etc.); (c) participação na formação e execução de políticas públicas com sugestões e correção de rumo dentro dos principais insertos na Constituição Federal, sopesando-se as carências locais; (d) sugestões no âmbito normativo para aperfeiçoamento da atividade pública e também particular; (e) instrumentalização estratégica na resolução do problema de forma global extrajudicialmente (termos de ajustamento) ou via ação civil pública (Alonso Jr., 2006, p. 185).

Por outro lado, tem-se a tese defendida pelo advogado José Carlos Baptista Puoli (2005), que parte do exame do atual quadro de funções e princípios estruturantes do Ministério Público e verifica existir hoje uma efetiva carência de formas e meios de controle dos poderes exercidos pelos membros desta instituição. Esta falta de controle é potencializada nos casos da atuação ministerial em sede de interesses metaindividuais, eis que, nesta seara, é muito ampla a margem de liberdade deixada ao promotor para verificar se o caso exige sua atuação e para decidir sobre quais as efetivas medidas a ser tomadas na busca do interesse público concretamente visado, qual é o formado, parte com base nas regras legais, parte com base em decisões do próprio agente que complementou a moldura das regras genéricas de prescrição de tais interesses.

Tendo fundamento nestas constatações, o estudo prossegue, apontando ter o Estado, em tese, o dever de reparar os danos causados por ato funcional do Ministério Público, sendo que, para o deferimento da indenização, há de haver a análise das condições concretas do caso. Verificou-se, ainda, ter o Estado o dever de denunciar a lide o promotor nos casos de culpa grave, dolo ou abuso de poder, sendo que, nos casos de abuso (extrajudicial ou judicial) do poder ministerial, a demanda de responsabilidade civil poderá ser ajuizada diretamente em face do agente. Analisaram-se, por fim, os instrumentos extrajudiciais e judiciais postos à disposição do MP para atuação no campo dos interesses metaindividuais, verificando em quais situações esta atuação poderá dar ensejo à responsabilidade civil.

\footnotetext{
${ }^{15} \mathrm{O}$ protocolado geral sobre resíduos possibilitou a interação do Ministério Público com a Cetesb para o desenvolvimento de melhor fiscalização na área dos resíduos industriais. Na área dos resíduos provenientes de estabelecimento de saúde, o Ministério Público intermediou conflito entre a Prefeitura Municipal de São Paulo e a Cetesb, com a celebração de TAC que viabilizou o funcionamento de Unidade de Tratamento de Resíduos Hospitalares na Capital (Procedimento Investigatório 127/97).
} 


\title{
3.2 Ação Popular Ambiental
}

A ação popular está prevista na Lei 4.717/65; porém, a legitimidade para a propositura está consignada no art. $5^{\circ}$, inciso LXXIII, da Constituição Federal:

\begin{abstract}
qualquer cidadão é parte legítima para propor ação popular que vise a anular ato lesivo ao patrimônio público ou de entidade de que o Estado participe, à moralidade administrativa, ao meio ambiente e ao patrimônio histórico e cultural, ficando o autor, salvo comprovada máfé, isento de custas judiciais e do ônus da sucumbência.
\end{abstract}

Assim, a ação popular constitui outro instrumento para a tutela do direito difuso ambiental, por meio do qual o cidadão visa a evitar ou anular ato lesivo ao patrimônio público ou de entidade de que o Estado participe ou ato que atente à moralidade administrativa, ao meio ambiente e ao patrimônio histórico e cultural. É um meio de participação política extremamente importante que, todavia, deve ser promovido pela atuação jurídica do cidadão, individualmente, sem a necessidade de recorrer a um grupo social ou entidade.

O sujeito ativo é o cidadão (art. $1^{\circ}$ da Lei 4.717/65), ou seja, pessoa física titular e no gozo dos direitos políticos, que pode ser brasileiro nato/naturalizado ou português equiparado no pleno exercício de seus direitos políticos.

O sujeito passivo vem determinado pelo art. $6^{\circ}$ da Lei $4.717 / 65$, podendo a ação ser proposta contra as pessoas públicas ou privadas e as entidades referidas no art. $1^{\circ}$, contra as autoridades, funcionários ou administradores que houverem autorizado, aprovado, ratificado ou praticado o ato impugnado, ou que, por omissas, tiverem dado oportunidade à lesão, e contra os beneficiários diretos do ato.

$\mathrm{O} \S 1^{\circ}$ deste dispositivo legal adverte que, se não houver benefício direto do ato lesivo, ou se for ele indeterminado ou desconhecido, a ação será proposta somente contra as outras pessoas indicadas neste artigo.

É importante observar que o Ministério Público acompanhará a ação, cabendo-lhe apressar a produção da prova e promover a responsabilidade, civil ou criminal, dos que nela incidirem, sendo-lhe vedado, em qualquer hipótese, assumir a defesa do ato impugnado ou dos seus autores.

Pelo disposto no art. 11 da Lei 4.717/65, qualquer ato administrativo pode ser anulado se potencial ou concretamente lesivo ao meio ambiente, por intermédio da ação popular, havendo a possibilidade de condenação dos responsáveis e beneficiários pelo ato lesivo em perdas e danos. Todavia, analisando os textos normativos referentes à ação popular (arts. $1^{\circ} \mathrm{e}$ 
$11^{\circ}$ da Lei $4.717 / 6$, e art. $5^{\circ}$, LXXIII, da CF), não se pode interpretá-los como ação de reparação civil.

Nesse sentido, têm decidido nossos Tribunais:

Ação popular - Pedido meramente indenizatório, por má execução de obra pública, regularmente contratada pela Administração Pública Inadmissibilidade - A ação popular tem por finalidade invalidação de ato administrativo ou contrato ilegais e lesivos ao erário público, sendo o pedido indenizatório mera consequiência - Extinção do processo decretada - Imposição de ônus de sucumbência Inadmissibilidade, salvo quando comprovada má-fé dos autores populares - Art. $5^{\circ}$, LXXIII - Recursos parcialmente providos ${ }^{16}$.

Toshio Mukai entende que a ação popular não se presta para a plenitude da defesa ambiental, em termos de abrangência de todas as hipóteses de danos potenciais ou não do meio ambiente, pois ela somente será viável naquelas hipóteses de agressões ao meio ambiente por atividades dependentes de autorizações, para o seu exercício, do Poder Público, como condição para a procedência da ação a ilegalidade do ato (Mukai, 1998).

Dessa forma, mesmo com o advento da Carta Magna, existem limites na ação popular para a tutela ambiental, pois esta não se presta à reparação do dano, senão avançaria no campo de incidência da ação civil pública.

\subsection{Mandado de Segurança Coletivo Ambiental}

O mandado de segurança coletivo é o mesmo remédio processual constitucional que já se configurava no mandado de segurança tradicional (Lei 1.533/51), mas adquiriu legitimidade para que os interesses coletivos fossem tutelados pelos legitimados para fazê-lo, ou seja, aqueles dispostos no art. 82 do CDC. Visa a tutelar os interesses de caráter difuso, tendo como conseqüência a legitimação ativa para a defesa desses interesses, expressa no art. $5^{\circ}$, incisos LXIX e LXX, da CF.

O mandato de segurança é proposto contra autoridade coatora responsável pela ilegalidade ou abuso de poder: agente público investido de poder de decisão para suprir a omissão lesiva de direito líquido e certo (não é mero executor); ou o particular exercente de função pública.

Analisando-se a finalidade do mandado de segurança coletivo constitucional e a função institucional do Ministério Público, observa-se a viabilidade processual no inciso LXX do art. $5^{\circ}$ da Carta Magna, diferenciando-se apenas quanto à sua legitimação, ou seja, a

\footnotetext{
${ }^{16}$ TJSP, 8 a Câm. De Direito Público, Ap. Cív 7.313-5 Pindamonhangaba, rel. José Santana, j. 05.11.1997, v.u.
} 
impetração para defesa dos interesses coletivos liga-se exclusivamente à legitimação ativa para a causa.

Desse modo, os legitimados do inciso LXX não são os únicos para a impetração do mandado de segurança coletivo; o rol elencado no permissivo não é taxativo em sede constitucional e, muito menos, em sede infraconstitucional, como se verifica no art. 82 do CDC.

Esclarece Celso Fiorillo que:

nos moldes estabelecidos pela Constituição Federal de 1988 e pela Lei 6.938/81, constatamos que o meio ambiente ecologicamente equilibrado é um direito líquido e certo. Todavia, ao exercemos o direito de ação de mandado de segurança ambiental, a realização desses dois requisitos - liquidez e certeza - estará adstrita à demonstração de que a violação do direito impede o desfrute de um meio ambiente sadio e equilibrado, a contento do que prevê a Constituição. Verificada aludida situação, presentes estarão a liquidez e a certeza do direito pleiteado em sede de mandado de segurança (Fiorillo, 2001, p.280).

Observa-se, ainda, que, no caso dos legitimados para propor o mandado de segurança, quando for constituído como partido político, é obrigatória representação no Congresso Nacional; quanto organização sindical, entidade de classe ou associação, estar legalmente constituída e em funcionamento há pelo menos um ano, em defesa dos interesses de seus membros ou associados.

Para que se configure a representação do partido político bastará a existência de um único parlamentar na Câmara ou no Senado. Tem-se firmado entendimento pelo qual partidos políticos podem representar somente seus filiados políticos e apenas na defesa de direitos políticos.

Quanto ao objeto a ser pleiteado pelos legitimados, membros ou associados de organização sindical ou entidade de classe ou associação, nem sempre estará vinculado apenas aos estatutos destas, podendo ser mais amplo, pois, dentre os interesses de seus membros estariam, com certeza, inseridas preocupações com o consumidor e o meio ambiente, entre outros direitos difusos.

Nesta linha, Ada Pellegrini Grinover salienta que

a interpretação que restringisse o objeto da segurança coletiva aos interesses dos membros da categoria fugiria ao critério da maior amplitude do instrumento potenciado. E ainda, a adotar-se esta posição, chegaríamos à conclusão de que o dispositivo é supérfluo, absorvido como ficaria, para os sindicatos, pelo disposto no inc. III do art. $8^{\circ}$ e, para as entidades, pelo inc. XXI do art. $5^{\circ}$ (Grinover, 1990, p. 21). 
Dessa forma, aos legitimados é constitucionalmente possível, nos termos do art. $5^{\circ}$, LXIX, proteger direito líquido e certo da sociedade, obtendo-se, por exemplo, anulação de um licenciamento ambiental conseguido sem os devidos trâmites legais, pois se trata de direito de todos ver incidir as regras preventivas dentro do princípio da legalidade, objetivando evitar impactos ambientais.

\subsection{Mandado de injunção em matéria ambiental}

O mandado de injunção está previsto no art. $5^{\circ}$, inciso LXXI da CF. Sua utilização é possível quando o intuito é garantir a proteção ambiental.

Dessa forma, quando se estiver diante de um caso de falta de norma regulamentadora referente à matéria ambiental e esta omissão normativa estiver tornando inviável o exercício de direitos e liberdades constitucionais e prerrogativas inerentes à nacionalidade, soberania ou cidadania, pode-se impetrar mandado de injunção para pleitear a regulamentação, sob pena de ofensa à $\mathrm{CF}$, por omissão.

Este instrumento pode ser impetrado por qualquer pessoa física ou jurídica contra aquele que detém competência e poder para suprir a ausência da norma, por exemplo, Legislativo, Executivo, Judiciário etc. Quando se tratar de interesse difuso e coletivo, mesmo que impetrado individualmente, seu efeito atingirá a todos.

José Afonso da Silva fornece exemplo deste alcance coletivo na implementação específica do direito de participação dos trabalhadores no lucro das empresas (art. $7^{\circ}, \mathrm{XI}$, da $\mathrm{CF}$ ). "Se essa regulamentação não vem, o direito aí previsto fica inviabilizado, e isso é pressuposto do mandado de injunção" (Silva, 1992, p. 403).

\subsection{Ação Direta de Inconstitucionalidade (Adin) de Lei ou Ato Normativo em matéria ambiental}

A CF estabelece, no art. 102, inciso I, letra "a", que compete ao Supremo Tribunal Federal (STF) a guarda da Constituição, cabendo-lhe processar e julgar a Ação Direta de Inconstitucionalidade (Adin) de lei ou ato normativo federal ou estadual.

Os entes legitimados para interpor a Adin estão elencados no art. 103 da CF e na Lei 9.868/99: presidente da República, Mesa do Senado, da Câmara dos Deputados, da Assembléia Legislativa ou da Câmara Legislativa do Distrito Federal, governador do Estado 
ou do Distrito Federal, procurador-geral da República, Conselho Federal da Ordem dos Advogados do Brasil, partido político com representação no Congresso Nacional, confederação sindical ou entidade de classe de âmbito nacional.

Assim, observada a legitimação legal, será possível a propositura de uma Adin contra lei ou ato normativo federal ou estadual que esteja ofendendo a Carta Magna no tocante às disposições sobre o meio ambiente. Nesse caso, a finalidade é proteger o ordenamento jurídico como um todo visando a retirar do sistema a lei ou ato que contraria a lei maior. Uma vez restituído o direito, esta ação possui efeito erga omnes, ou seja, atinge todos os indivíduos de uma determinada população que tiveram seu direito cerceado pela norma.

\subsection{Ação Declaratória de Constitucionalidade (Adecon ou ADC)}

O processamento e o julgamento da Ação Declaratória de Constitucionalidade (Adecon) de lei ou ato normativo federal compete ao STF, conforme disposto no art. 102, inciso I, letra "a" - 2a parte da CF.

Depois de observada a legitimação prevista pelo art. 103 da CF, será possível a propositura de uma Adecon de lei ou ato normativo federal no tocante às disposições sobre o meio ambiente. Nesse caso, em virtude da controvérsia levantada, a finalidade é confirmar a constitucionalidade do ato jurídico e mantê-lo no ordenamento.

Todavia, diante das medidas expostas, é evidente que a ACP, é a ação com maior alcance na preservação e implementação de direitos fundamentais. Assim, no capítulo seguinte estudará um caso prático de ACP, que visa a apuração de responsabilidades na contaminação de solo na Vila Carioca. 


\section{Capítulo IV - Estudo de Caso: Ação Civil Pública Proposta para a} Apuração de Responsabilidades e Contaminação do Solo na Vila Carioca

Em 1978, o Estado tomou providências depois da divulgação da mídia e da pressão dos moradores, liderados por Lois Gibbs, uma mãe que se engajou na causa após ver seus filhos contraírem uma doença após a outra. A escola foi fechada e as 239 casas mais próximas à área foram evacuadas, compradas e destruídas.

Dois anos mais tarde, após protestos de famílias que ainda viviam na região, o presidente Jimmy Carter declarou Love Canal como uma área-desastre, realocou as famílias remanescentes e ofereceu fundos federais para comprar mais 564 casas.

G. Tyler Miller Jr. (2007, p. 444-5)

\subsection{Considerações, metodologia e análise sobre o objeto de estudo}

A proposta de investigação levada a efeito no presente trabalho é conjeturar as razões que dificultam o andamento de uma ação ambiental, fazendo com que o julgamento de uma questão relacionada à proteção do meio ambiente se arraste por 20 anos, provocando um aumento do descrédito do Poder Judiciário, bem como agravando as conseqüências de um dano. O estudo desenvolve a análise da ACP ambiental proposta pelo Ministério Público do Estado de São Paulo contra a Shell Brasil SA e a Cetesb. Em face dos problemas enfrentados na prática, como a lentidão no andamento das ações, ou mesmo a dificuldade encontrada em condenar judicialmente a reparar os danos causados por suas atividades nocivas, busca-se identificar os motivos de tanta demora para resolver um problema - que quase sempre é emergencial, uma vez que envolve o meio ambiente e as cruéis consequiências para a saúde e a vida humanas. 
Primeiramente, é importante entender como o caso chegou até o Ministério Público. Assim, far-se-á um relatório da ACP, que conta atualmente com 18 volumes, mais de 3.500 páginas e ainda se encontra em fase de instrução, ou seja, na fase de produção de provas; logo, não houve julgamento do mérito da ação.

O objeto deste estudo é importante para analisar a efetividade das medidas judiciais, ou das atuações na prática, para garantir o direito à saúde, principalmente em áreas contaminadas. Importante também porque pode contribuir para auxiliar na construção de um modelo de cidadania. Impulsionado pelo tema ambiental ou conflitos socioambientais, o exercício da cidadania seria uma forma de participação da sociedade em outros debates sobre direitos, permitindo uma análise do papel do Ministério Público Estadual e do Poder Judiciário. Afinal, nada mais é do que garantir o direito "ao meio ambiente ecologicamente equilibrado, bem de uso comum do povo essencial à sadia qualidade de vida" (art. 225, caput da CF).

A pesquisa realizada parte da análise da ação civil pública proposta para atribuir as responsabilidades das Requeridas (Shell Brasil SA e Cetesb), em razão das atividades da primeira, a qual contaminou o solo do terreno ocupado na Vila Carioca, e da segunda, que não fiscalizou e inspecionou a contento, deixando de cumprir suas atribuições e responsabilidades. Incluiu, ainda, entrevistas com os atores envolvidos, quais sejam: o representante do Ministério Público do Estado, a Cetesb e o Centro de Vigilância Sanitária (CVS), sendo que a empresa Shell do Brasil SA e o representante do Poder Judiciário se recusaram a participar da pesquisa, alegando que a ACP não foi objeto de julgamento.

Quanto à metodologia utilizada, é preciso esclarecer que o termo metodologia é entendido aqui como o conhecimento crítico dos caminhos do processo científico, indagando e questionando acerca de seus limites e possibilidades (Demo, 1989).

A metodologia qualitativa foi utilizada neste trabalho, uma vez que esta possui uma característica própria, que é a flexibilidade, principalmente quanto às técnicas de coleta de dados, incorporando aquelas mais adequadas à observação que está sendo feita. Outra característica importante consiste na heterodoxia no momento da análise dos dados. "A variedade de material obtido qualitativamente exige do pesquisador uma capacidade integrativa e analítica que, por sua vez, depende do desenvolvimento de uma capacidade criadora e intuitiva" (Martins, 2004).

No contexto deste trabalho, todavia, observa-se, ainda, que se trata de uma pesquisa interdisciplinar com caráter sociológico, que envolve três áreas das ciências: direito, saúde e meio ambiente, sendo que os dados e as informações devem ser analisadas pelo pesquisador 
apenas sob a influência de conhecimentos científicos, no caso do direito, apenas para auxiliar nos esclarecimentos e não influenciá-las.

Para Shimura (2005), a rigor, questões como direito à saúde ou dignidade da pessoa humana atingiram e atingem a todos, ricos ou pobres, jovens ou não, independentemente de aspectos religiosos ou partidários, questões essas que não fugiram à preocupação dos demais sistemas jurídicos.

Por sua vez, o Prof. Mancuso (2002, p. 19) observa que o direito tem passado por fases ou gerações. Os de primeira geração seriam os direitos individuais à liberdade e igualdade; os de segunda geração seriam os direitos sociais, concernentes ao dever estatal de prover as necessidades e garantias materiais mínimas da população (como educação e saúde); e os de terceira geração seriam os decorrentes da sociedade de massa, inspirados pelos movimentos ecológicos de viver e sobreviver num ambiente não poluído.

O direito ao meio ambiente saudável aparece inserido no pólo de proteção jurídica, chamado de direitos de terceira geração, na medida em que não se destinam especificamente à proteção de interesses de um grupo ou de um determinado Estado - hoje podem ser chamados difusos - porque desde 1990 tais interesses contam com expresso conceito legal: art. 81, III, da Lei 8.078/90 - Código de Defesa do Consumidor (CDC).

ACP aparece inserida nesse contexto, como instrumento jurídico disponível no nosso ordenamento para a proteção ambiental e que tem se demonstrado o meio mais recorrente na busca da resolução dos conflitos ambientais por via judicial. Lamentavelmente, porém, não parece ser célere e eficiente como exige o rigor da lei na defesa da Constituição Federal.

Comparado a outros instrumentos de proteção do meio ambiente, como a Ação Popular - na qual a participação do cidadão como legitimado ativo para propô-la se dá de maneira tímida e ainda encontra diversas dificuldades no campo prático, já que a própria legislação atual não viabiliza meios de melhor efetivá-la -, o instrumento processual aqui estudado tem sido, assim, o meio que viabiliza o espaço de discussão sobre a questão da tutela ambiental e seus conflitos atuais.

Por essa garantia legal constrói-se, por meio das denúncias, das sindicâncias, dos procedimentos processuais e dos TACs, um espaço dialógico aberto aos atores sociais envolvidos na questão ambiental. Nesse espaço destaca-se a participação da sociedade civil através de indivíduos isolados, de organizações não-governamentais, de movimentos sociais e, em especial, da atuação do Ministério Público como participante do discurso e intermediário na resolução dos conflitos. 
Como já mencionado, a hipótese de investigação do presente trabalho é conjeturar prospectivamente sinais de colapso de um modelo de cidadania tutelada, que tem como base a noção de acesso à Justiça e a própria juridicidade na tradição brasileira. Nesse sentido, tanto o aparelho estatal apresenta sinais de obsolescência, como a sociedade civil apresenta indicadores de falta de familiaridade com uma militância cívica que relativize judicialmente o espaço público.

O método utilizado para confirmar a hipótese foi a análise concreta da ACP Ambiental proposta pelo Ministério Público do Estado de São Paulo. Para tanto, foram realizadas mais de 30 diligências ao cartório que atende à 10 a Vara da Fazenda Pública da Comarca da Capital, sendo que cada uma durava cerca de duas horas, para anotações rápidas, pois as condições de pesquisa e leitura dos autos processuais eram muito precárias e tinham que ser realizadas no balcão de atendimento, uma vez que o MM. Juiz não pôde disponibilizar uma mesa e uma cadeira para a consulta dos 18 volumes da ACP em questão.

A pesquisa foi realizada utilizando-se os dados obtidos nos autos da Ação em questão e informações fornecidas pelo representante do Ministério Público Estadual da $2^{\text {a }}$ PJMA da Capital, responsável por promover a tutela judicial relativa ao meio ambiente no Estado de São Paulo. Os procedimentos realizados, que serão abordados neste capítulo, foram: levantamento e acompanhamento da ACP Ambiental em andamento; leitura do inquérito civil que deu origem à $\mathrm{ACP}$, bem como entrevistas com o representante do Ministério Público Estadual, responsável pela tutela ambiental; entrevistas com a Cetesb, ré na ACP, denunciada por negligenciar a fiscalização ambiental; e entrevistas com o CVS. A empresa Shell do Brasil, também ré na ACP, e o MM. Juiz da $10^{\text {a }}$ Vara da Fazenda Pública, onde tramita da $\mathrm{ACP}$, não quiseram se manifestar sobre a questão, tendo em vista que ainda não foi julgada.

Diante do objeto de estudo, e por se tratar de um caso de contaminação do solo na Vila Carioca, antes de abordar as questões relativas à ACP, primeiramente se apresentará a evolução urbana na região, bem como outros fatos pertinentes, para melhor compreensão e análise do caso. 


\subsection{Evolução histórica da região da Vila Carioca e fatos relativos à contaminação}

A industrialização na cidade de São Paulo foi incrementada no início do século XX. Nas regiões da Barra Funda, Mooca, Ipiranga, Brás, Cambuci, entre outros bairros, o surgimento da atividade industrial está relacionado ao percurso das estradas de ferro. $\mathrm{O}$ transporte pela Ferrovia Santos-Jundiaí viabilizava o fluxo de matéria-prima e do produto final.

A referência do crescimento do setor da indústria é de um período em que o crescimento populacional no município de São Paulo aumentou 268\% em 10 anos, passando de 64.934 habitantes em 1890 para 239.820 em 1900, o que ilustra bem as transformações urbanas por que passou a Capital. Segundo a citação de Paul Singer, "a indústria emerge da tempestade do Encilhamento solidamente estabelecida, principalmente o ramo da fiação e da tecelagem" (apud Valentim, 2005, p. 18).

Segundo Valentim (2005), em 1906, verificou-se a existência, na região do Ipiranga, da Fiação, Tecelagem e Estamparia Ipiranga-Jafet. Em 1907, instalou-se na mesma região a Indústria de Linhas Corrente SA e, em 1909, a Indústria Silex, do ramo metalúrgico. As Indústrias Reunidas Francisco Matarazzo (IRFM) adquiriram, em 1918, a fábrica de sabão, óleo e graxa Pamplona, localizada próxima do Rio Tamanduateí e Ribeirão dos Meninos, instalada desde 1896. "No local, eram fabricados produtos à base de gordura animal, passando, a partir dos anos 30, a produzir uma variada gama de produtos químicos" (Cunha, 1997, p. 47) ${ }^{17}$.

Nos anos 20, foi instalada a primeira linha de montagem de veículos na Av. Presidente Wilson, a General Motors, e na sequiência outras indústrias se instalaram na região: a Ford, a Volkswagen, a Toyota, a Scania e a Ultragás.

Este contexto de acelerada ocupação do território nas proximidades da Vila Carioca, na década de 40, com características de bairro industrial, foi bem relatado por Raul de Andrade e Silva, conforme citado por Langenbuch:

O viajante que parte de São Paulo no rumo de Santos, pela São Paulo Railway, observa em ambos os lados da estrada de ferro aspectos de vida industrial já muito desenvolvida. À direita e à esquerda sucedemse os grandes armazéns e depósitos, erguem-se muros de fábricas

\footnotetext{
${ }^{17}$ Segundo Cunha (1997, p. 47), em 1932 iniciou-se a produção de ácido sulfúrico, celulose de linter e rayon. A partir de 1946, as IRFM passaram a produzir soda cáustica, cloro e seus compostos e BHC técnico. Nas décadas de 70 e 80 entraram em operação outras unidades de produção de substâncias químicas variadas. Tais atividades geraram grandes passivos ambientais, até hoje não remediados.
} 
junto ao limite da linha férrea, e quando a perspectiva se amplia percebem-se ao longe os vultos das chaminés dos bairros industriais: Braz, Mooca, Ipiranga. Além da estação deste nome, vai desaparecendo o panorama industrial, substituído por extensão de terrenos ainda vazios, à espera de ocupação. Vêem-se apenas manchas mais ou menos afastadas de casas isoladas ou em grupos reduzidos, localizados nos bairros extremos da capital. Mas, logo adiante, a entrada do município de Santo André, o panorama industrial é de novo anunciado por dois grandes estabelecimentos, à esquerda fábricas das indústrias Francisco Matarazzo, à direita a fábrica de louças da firma Barros Loureiro. Reproduzem-se aquela sucessão de fábricas e armazéns, menos compacta agora, até atingir-se a estação ferroviária de Santo André (1970, p.142).

Na década de 50, instalou-se, próxima da confluência do Ribeirão dos Meninos com o Rio Tamanduateí, vizinho às Indústrias Matarazzo, e nas proximidades da linha férrea SantosJundiaí, a empresa multinacional (de origem holandesa) Shell do Brasil, para base de estocagem e distribuição de derivados de petróleo provenientes do porto de Santos.

Em 1958 uma parte da área da empresa era destinada à formulação de agrotóxicos organoclorados, atividade que se estendeu até 1978, quando foi transferida para o município de Paulínia.

Outros fatos importantes que colaboraram para a situação de degradação ambiental da região, conforme lembrou Valentim, é que as indústrias locais manipulavam várias substâncias químicas, "que possivelmente ganhavam mobilidade e se espalhavam no ambiente por ocasião das inundações. As enchentes serviram também como argumento para livrar responsabilidade quanto a eventuais contaminações." (Valentim, 2005, p. 117), sob a alegação que as águas das chuvas transportavam os resíduos poluentes das indústrias vizinhas.

A empresa Shell, para suas instalações, na década de 1940, adquiriu dois lotes, separados pela Av. Presidente Wilson. O menor deles, conhecido como BIP II (Base do Ipiranga II), tem cerca de $24.000 \mathrm{~m}^{2}$ e é lindeiro à ferrovia. O segundo foi identificado como BIP I, com cerca de $180.000 \mathrm{~m}^{2}$, e faz divisa, de um lado, com lotes residenciais, e do outro, com o pátio do Detran, onde antigamente funcionou uma refinaria de petróleo do Grupo de Indústrias Matarazzo.

Entre 1958 e 1978, a parte do sítio BIP II, segundo Valentim,

passou a ser utilizado em processos de formulação de agroquímicos organoclorados e organofosforado, produzindo, em média, 5.000 a 6.000 toneladas por ano destes produtos. Até 1970, o recebimento e a distribuição dos produtos acabados eram feitos por desvio ferroviário. No mesmo local, entre o início dos anos 60 até os anos 80, foram desenvolvidas também atividades de envase de produtos petroquímicos adquiridos a granel, armazenagem de produtos embalados e formulação de detergentes industriais, além da estocagem 
de produtos lubrificantes (esta atividade perdurou até 2003) (2005, p. 127).

O outro sítio (BIP I) é uma das maiores bases de estocagem de petróleo operadas pela Shell do Brasil. A área de $180.000 \mathrm{~m}^{2}$ é ocupada por instalações de tancagem, tubulações, plataformas de recebimento e distribuição de produtos, laboratório, central de controle e oficinas de manutenção, além de edificações desativadas. Constam, ainda, 37 tanques aéreos verticais, que desde os anos 40 armazenam volume superior a $65.000 \mathrm{~m}^{3}$ de produtos tão diversos quanto álcool anidro e hidratado, óleo diesel, gasolina automotiva e solventes orgânicos, como tolueno e xileno.

Relata, ainda, Valentim que alguns

possíveis acidentes ocorridos nesses mais de 50 anos de atividades da Shell no local, que resultaram em lançamentos de contaminantes no ambiente, pequenos vazamentos ao longo dos anos ou práticas operacionais pouco cuidadosas são as prováveis razões da contaminação do solo e das águas subterrâneas no interior das bases da empresa na Vila Carioca e no seu entorno imediato, cujas dimensões e consequiências só começaram a ser efetivamente avaliadas a partir de 1993 (2005, p. 129)

Em 7 de janeiro de 1993 o Ministério Público do Estado de São Paulo recebeu a representação formulada pela Associação Civil Greenpeace contra a empresa Shell do Brasil, com informações obtidas por meio do Sindicato dos Trabalhadores no Comércio de Minerais e Derivados de Petróleo do Estado de São Paulo, de que a empresa mantinha em área de sua responsabilidade depósito de chumbo, e que já estaria ocorrendo contaminação do solo em toda a região. Em razão disto, o MP instaurou o Inquérito Civil $n^{\circ}$ 001/93 para investigar a existência de contaminação ambiental.

A Cetesb, todavia, como órgão fiscalizador, somente ficou sabendo que o local havia sido utilizado para a manipulação de pesticidas em 1999, por ocasião das investigações ambientais, o que resultou em autuação da empresa.

As investigações ambientais indicaram contaminantes como BTX (benzeno, tolueno e xileno) e metais pesados (chumbo) enterrados em diversos locais do site da empresa.

Entre 1993 e 1999 foram adotadas medidas para remediação do interior do site, com a remoção dos focos primários dessas substâncias do solo. Entre os anos 1999 e 2000 foram descobertos novos focos de contaminação, na área conhecida como Colorado (antiga unidade esportiva e recreativa), com a detecção de compostos organoclorados (conhecidos como drins), resultante de práticas de manipulação de pesticidas, até então desconhecidas naquele local. Posteriormente, foi identificada contaminação por drins também na BIP II, onde, por muito tempo, se formulou pesticidas clorados. (Valentim, 2005, p. 130) 
Diante deste contexto, em março de 2002, o Ministério Público do Estado de São Paulo propôs ACP contra a empresa Shell do Brasil e contra a Cetesb, visando a garantir a execução de medidas complementares de diagnóstico e remediação ambiental, além de possível avaliação e tratamento de saúde dos atingidos, entre outros pedidos. Os fatos e direitos motivadores da ACP, as defesas e entrevistas e dados pertinentes a este caso de contaminação de solo serão abordados nos tópicos a seguir.

Dentro do contexto deste capítulo, ou seja, analisando a ACP em questão, enfocaremos os atores envolvidos, com base nos documentos de acusação e defesa e depoimentos sobre o caso.

\subsubsection{Dos Atores envolvidos na ACP}

\subsubsection{Ministério Público}

No tocante ao pedido inicial, podem-se destacar os aspectos seguintes.

Os fatos e direito que fundamentam a ACP foram apresentados no tópico anterior, e embasado nestes o MP requer o reconhecimento da responsabilidade dos Requeridos Shell do Brasil S A e da Cetesb, conforme segue:

\section{I) Shell Brasil SA}

A responsabilidade da Shell pelos danos ambientais (descontaminação e remediação da área contaminada/poluída, seguida de recuperação e recondução da área ao estado ambiental anterior, inclusive indenização dos danos que forem considerados tecnicamente irreversíveis), além das indenizações pelos danos causados às pessoas, que considera inafastável, com base no art. $225, \S 3^{\circ}$ da CF.

Salienta-se que este dispositivo constitucional dispõe sobre a obrigação daquele que empreende de recuperar e indenizar os danos ambientais que causar, responsabilidade esta de cunho objetivo, ou seja, não se investiga dolo ou culpa, mas, tão-somente se há a atividade, o dano e o nexo de causalidade, o que se deduz do laudo técnico e demais elementos colecionados nos autos.

Tal responsabilidade, todavia, impõe-se com base no art. $3^{\circ}$, inciso IV da Lei 6.938/81, que considera poluidor toda "pessoa física ou jurídica, de direito público ou privado, responsável, direta ou indiretamente, por atividade causadora de degradação ambiental”, ou seja, o artigo $14, \S 1^{\circ}$ dessa mesma lei dispõe que tal responsabilidade é objetiva, na medida 
em que é o poluidor "obrigado independentemente de existência de culpa, a indenizar ou reparar os danos causados ao meio ambiente e a terceiros, efetuados por sua atividade”.

\section{II) Cetesb}

Consoante às considerações apresentadas pelo laudo técnico, a Shell nunca adotou providências efetivas para a solução do problema. Pelo contrário, sempre adiou e prorrogou soluções e ações que deveria ter adotado e, embora a situação permanecesse grave (conforme se concluiu), o órgão ambiental estadual, a quem compete fiscalizar e reprimir condutas ofensivas ao meio ambiente no Estado de São Paulo, a quem coube o gerenciamento administrativo do problema, sempre referendou e avalizou as propostas da Shell (propostas e ações desenvolvidas sem efetividade, que não avançaram sobre o problema). E o fez, autorizando, por inúmeras vezes, prorrogações de prazos para cumprimento de ações que eram devidas.

Ademais, a Cetesb afirmou à Promotoria de Justiça que o processo de remediação estava em curso e a contento, não havendo providências adicionais a serem adotadas, pois não havia risco às pessoas. Entretanto, a situação demonstrada no laudo técnico era exatamente a oposta, de extrema gravidade, o que, confirmando-se, exigia rigor na denúncia por parte do órgão ambiental, qual seja, a adoção de medidas administrativas efetivas para a solução da situação danosa.

Assim, a responsabilidade da Cetesb é apontada como evidente, conforme dispõe o art. $225, \S 3^{\circ}$ da $\mathrm{CF}$, que coloca em posição de solidariedade todos aqueles que contribuíram para o dano, manutenção do dano e agravamento da situação danosa ambiental.

Menciona-se, ainda, o art. $3^{\circ}$, inciso IV da Lei 6.938/81, que define como poluidor aquele que, direta ou indiretamente, é responsável pelos danos ambientais, e afirma que, no mínimo, a Cetesb é responsável indireta pela situação existente na área ocupada pela Shell,. Isto porque, com a condução administrativa deficiente do caso, possibilitou que a situação danosa ambiental fosse mantida, aumentando em muito o risco à saúde e vida das pessoas.

Deduz que a responsabilidade da Cetesb, nesse caso, é direta, pois referendou as iniciativas parciais da Shell, contribuindo diretamente para o estado de coisas que foi apontado.

Salienta, ainda, para fundamentar os pedidos, o disposto no art. $37, \S 6^{\circ}$ da CF. que diz: "As pessoas jurídicas de direito público e as de direito privado prestadoras de serviços públicos responderão pelos danos que seus agentes, nessa qualidade, causarem a terceiros, assegurado o direito de regresso contra o responsável nos casos de dolo ou culpa". 
Assim, conforme a teoria do risco administrativo, contida nesse dispositivo, fica claro que a responsabilidade do Estado é objetiva. Portanto, derivavam os danos ambientais apontados, também, da atuação deficiente da Cetesb, devendo o Órgão ambiental responder integralmente pelos danos, sua recuperação, ou seja, por todos os efeitos derivados da situação danosa ambiental.

Diante do exposto, o MP requer, em caráter principal:

1 - a citação pessoal das requeridas, a fim de, querendo, contestarem o presente feito, sob pena de revelia;

2 - seja julgada procedente a ação civil pública ambiental, convalidando-se a liminar e condenando-se a SHELL BRASIL SA à OBRIGAÇÃO DE NÃO FAZER, consistente em não despejar, não derramar, não lançar, não dispor, não depositar, não acumular e não infiltrar no meio ambiente local (local dos fatos tratados nesta ação), e sem prévio e adequado tratamento, quaisquer resíduos, efluentes, contaminantes ou poluentes, sob pena de multa diária de $\mathrm{R} \$$ 1.000.000,00 (um milhão de reais) pelo descumprimento; 3 - seja ainda julgada procedente a presente ACP-ambiental, convalidando-se a liminar e condenando-se as requeridas, solidariamente, a:

a) OBRIGAÇÃO DE FAZER, consistente em procederem, no prazo de 180 dias, e às suas expensas, a remoção e destinação final ambientalmente adequada de todos os resíduos existentes no local objeto da ação, onde a empresa mantinha a mantêm atividades (durante todo o tempo de sua existência), incluindo área externa, outras dependências e prédios que ocupava e ocupa, inclusive remoção dos resíduos eventualmente existentes no entorno, que sejam de sua responsabilidade, tudo comprovando-se nos autos;

b) OBRIGAÇÃO DE FAZER, consistente em:

b.1) contratarem, às suas expensas, no prazo máximo de 60 (sessenta) dias, profissionais técnicos para atuação multidisciplinar, visando à elaboração de completo projeto e cronograma de medidas, obras, serviços e providências de descontaminação e posterior recuperação/reconstituição dos ambientes poluídos/degradados objeto da presente ação, com a correspondentes anotação e recolhimento da ART, na forma legal;

b.2) apresentarem à Secretaria Municipal de Meio Ambiente, na seqüência, no prazo de 15 dias, e ao Ibama, supletivamente, no mesmo prazo, o projeto e cronograma completo elaborado segundo o item acima (b.1), para merecerem avaliação dos órgãos;

b.3) obedecer a todas as imposições e recomendações emanadas dos Órgãos Públicos em referência, ficando igualmente obrigadas a providenciarem a eventual complementação, retificação e/ou atualização de quaisquer dados, informes, análises e/ou esclarecimentos dentro do prazo máximo de 30 (trinta) dias, contado da notificação/cientificação dos órgãos ambientais;

b.4) dar início, imediatamente após a aprovação, a todas as obras e medidas necessárias à reparação dos danos ambientais (descontaminação das áreas e posterior recuperação/reconstituição) oriundos das atividades da empresa SHELL e do abandono dos resíduos no local, incluindo a área do entorno atingida, obedecendo estritamente ao projeto e cronograma aprovados pelos órgãos, 
reparação essa que deverá incluir solo, subsolo, águas superficiais e subterrâneas, ou seja, toda a reparação necessária para devolver a área da empresa e do entorno, atingida pela contaminação, ao estado ambiental originário;

c) OBRIGAÇÃO DE DAR, consistente no pagamento de indenização pecuniária pelos danos ambientais tidos como tecnicamente irreversíveis, devendo tal numerário ser carreado ao Fundo Especial de Despesa e Reparação de Interesses Difusos e Coletivos Lesados;

d) INDENIZAR todos os danos dos trabalhadores, ex-trabalhadores (da empresa e empresas vizinhas) e moradores do entorno, em virtude da situação danosa ambiental verificada, inclusive danos morais, além dos danos derivados de sequielas permanentes em virtude da exposição e contaminação em tela;

e) INDENIZAR os consumidores, usuários de água de abastecimento público, e eventualmente a própria Companhia Concessionária, por danos decorrentes da eventual interrupção do abastecimento de água e/ou do próprio consumo de água imprópria e danos daí resultantes;

f) INDENIZAR os moradores do entorno, usuários de água colhida de poços (artesianos, semi-artesianos e comuns), por danos decorrentes da eventual interrupção de utilização desse sistema para captação de água e/ou do próprio consumo de água imprópria e danos daí resultantes.

Ademais das informações acima, buscou-se ouvir agentes deste processo, salientandose que já atuaram neste caso 15 promotores. O Promotor de Justiça, Dr. Geraldo Rangel França Neto $^{18}$, responsável pela Promotoria de Justiça de Meio Ambienta da Capital/SP no ano de 2006, pôde colaborar com a pesquisa fornecendo documentos e várias informações relacionadas ao procedimento do órgão, transcritas a seguir na ordem:

Inicialmente, no caso da Vila Carioca e da empresa Shell, parecia que haveria a possibilidade de acordo, ou seja, de firmar um TAC para remediar a área. Esta alternativa, porém, foi se tornando complicada, pois se trata de um bairro de industrialização antiga e que está adensado com residências.

Nos casos de áreas contaminadas, é difícil correlacionar a degradação ambiental com os casos de doenças ou agravos à saúde (situações que geram piora na condição de vida, mas não configuram doença) para as pessoas do entorno; nos casos de doenças ocupacionais este problema é mais evidenciado.

Neste processo, é importante buscar da categoria médica um posicionamento de probabilidade, analisando, no caso, a exposição e a possível relação da doença com a contaminação.

No caso em questão, o papel da Vigilância Sanitária foi decisivo, pois os técnicos foram enfáticos na atribuição dos problemas de saúde das pessoas à questão da contaminação.

\footnotetext{
${ }^{18}$ Entrevista realizada em São Paulo em 8/8/2006.
} 
Quanto às medidas judiciais utilizadas para pleitear direitos coletivos, saliente-se que o Inquérito Civil é instaurado para apurar os fatos, tendo em vista o poder inquisitivo, o que possibilita requisitar dados e informações, que podem ser úteis para embasar, posteriormente, a ACP.

Em termos de áreas contaminadas, o entrevistado Dr. Geraldo classificou como principais questões: 1) impedir o acesso de pessoas; 2) interromper a influência delas em áreas adjacentes; 3) e o que é mais importante, adequar a remediação ao tipo de uso, porque se se fizer um parque público a remediação vai ter se efetivar de uma forma, e se for fazer para área residencial a remediação tem que ser muito mais eficaz, porque as pessoas vão ficar por um tempo maior no local, e se forem para área industrial, já e possível haver outra forma de remediação. O mais indicado é fazer uma auditoria ambiental para saber qual o tipo de remediação a ser feita, para depois destinar a área ao novo uso.

Não se fala em descontaminação, pois é quase impossível levar a área às condições originais; por isso, fala-se em remediação. Para depois pedir uma indenização pelo dano ambiental, com base no CDC, podem-se defender os direitos individuais homogêneos, lógica que obriga a um pedido por toda a coletividade atingida, para depois cada cidadão executar o seu interesse, demonstrando cada um o tipo de dano que sofreu.

Inquérito civil é instaurado para apurar os fatos, para embasar posteriormente a ACP, segundo salientaram as Leis 6368/81, Lei Estadual 997/76 e Resolução Conama.

Quanto às medidas judiciais aplicadas para este tipo de ação, asseverou que, por exemplo, o Mandado de Segurança é possível, com base no CDC, pois permite ao MP e os colegitimados utilizar todas as ações para assegurar os direitos. Neste contexto, possibilita a utilização do MS, da medida cautelar, da antecipação de tutela, da ação de execução de título extrajudicial, ou seja, toda medida judicial passível de ser utilizada para pleitear ou defender direitos coletivos.

Chamou a atenção para a Lei de Crimes Ambientais (Lei 9605/98), que possui um pressuposto, para o não prosseguimento do processo criminal, o agente deve reparar o dano no âmbito do processo civil. Trata-se de um instrumento novo, para dar mais eficiência na atuação.

O promotor considera os maiores entraves encontrados aqueles relacionados à perícia, à falta de recursos, pois em casos de contaminação geralmente envolvem grandes áreas industriais, e antes de entrar com ação judicial é necessário que se faça uma perícia (com exames laboratoriais etc.). Já no inquérito civil, relatou experiência de obter auxílio e 
colaboração, principalmente de universidades, por exemplo, da USP, para a realização de exames e elaboração de laudos.

Outra questão que envolve interesses econômicos atribuiu é verificada quando uma empresa adquire um imóvel contaminado por preços baixos, para construir um grande empreendimento imobiliário supervalorizado. Hoje a preocupação é grande no momento do licenciamento ambiental, muita vezes o empreendedor tem de remediar a área antes de construir.

Outro problema afim ao interesse econômico está relacionado à disposição final dos resíduos, pois dispor corretamente o resíduo envolve um custo muito alto. Lembrando que há produtos químicos que exigem tratamentos específicos antes de serem dispostos.

Outra questão importante em termos jurídicos é a responsabilidade solidária, Lei 6938/81 art. $3^{\text {a }}$ inc. IV: no caso da empresa que contrata outra para dispor/transportar os resíduos, ela continua respondendo pela disposição, não transferiu a responsabilidade: todos os envolvidos são responsáveis solidariamente.

Outro ponto destacado na entrevista foi a união das áreas técnica, médica e jurídica, que ele considera muito importante. Não propõe ação sem antes consultar um técnico ou médico, pois estão envolvidos custos imensos. As perícias judiciais são caras em casos de ACP e o MP não tem verba para pagá-las.

O custo de perícia nas ações ACP ambientais, principalmente em áreas contaminadas, para ele, é uma questão que, em termos legislativos, teria de ser resolvida, porque pela Lei da ACP o réu não está obrigado a adiantar as despesas processuais para a perícia, então o MP tem de recorrer às universidades e outras instituições para baixar o custo.

Quanto às formas para o MP tomar conhecimento de áreas contaminadas, ele esclareceu que são várias hipóteses: através de informação, denúncia, notícia da Cetesb (ofício), representação ou mesmo da imprensa. Após a denúncia, o MP analisa a pertinência para instaurar o inquérito civil, quando é identificado o responsável e, se possível, tenta-se o TAC.

Segundo avalia, deveria existir em São Paulo um inventário mais preciso das áreas contaminadas. Foi sugerido à Cetesb que fizesse um estudo das prováveis regiões onde haveriam ACs, partindo-se das antigas áreas industriais, como Ipiranga, Mooca, Tatuapé (outros exemplos citados foram: Shopping Center Norte, que era um aterro, área do Parque Villa Lobos e áreas do entorno dos rios Pinheiros e Tietê). Seriam áreas suspeitas, que necessitariam de uma remediação adequada. Considera, hoje, mais graves as áreas dos postos de gasolina, geralmente contaminadas. 
Salienta, também, que existe a preocupação de informar a população, notificar e orientar as pessoas sobre como devem proceder quanto estão próximas ou em áreas contaminadas.

Quanto ao cumprimento do TAC, o MP se preocupa e acompanha um cronograma com as fases de execução.

\subsubsection{Shell do Brasil SA}

A empresa Shell do Brasil foi procurada por diversas vezes por esta autora, porém, por uma política interna, optou por não se manifestar. Em colaboração com a pesquisa forneceu algumas informações, via e-mail ${ }^{19}$, que apresentou como "um breve resumo sobre a questão", que não deixa de ser a versão da empresa sobre os fatos. Assim, seguem as informações nos termos em que foram transmitidos por sua Gerência de Assuntos Externos:

Em resposta a sua solicitação de entrevista informamos que infelizmente não poderemos atender. Não obstante essa impossibilidade, segue um breve resumo sobre a questão.

A Base de Distribuição de derivados de petróleo da Shell Brasil na Vila Carioca, bairro do Ipiranga, iniciou suas atividades no final da década de 40, é uma das maiores, mais antigas e hoje uma das mais modernas do Brasil, sendo responsável pelo abastecimento de um percentual significativo de todo o combustível consumido na capital e cercanias. Com o passar do tempo, o bairro do Ipiranga, mais especificamente a área conhecida como Vila Carioca, onde está instalada a Base da Shell Brasil, consolidou-se como pólo industrial, atraindo intensa atividade econômica por parte de variada gama de indústrias que ali se instalaram, dentre elas uma antiga refinaria e petroquímica. Por décadas e até o início dos anos 80, a regulamentação sobre impactos ambientais decorrentes de atividade industrial era inexistente e mesmo quando passou a existir tratou do tema de forma hoje repelida pela regulamentação vigente, particularmente no que se refere à destinação de resíduos industriais tais como borras resultantes das operações petrolíferas exercidas pela Shell e outras indústrias instaladas no local.

No exercício de suas atividades em quaisquer dos segmentos em que atua, a Shell prima pelo estrito cumprimento da legislação, inclusive e particularmente das regras ambientais. O histórico de impacto ambiental da Base da Shell na Vila Carioca é resultado de atividade ambiental dentro dos limites das regulamentações aplicáveis no passado, como é comum em várias áreas da atividade industrial. Em resposta à evolução regulamentar sobre o meio ambiente, a Shell Brasil tem buscado a identificação de legados ambientais nas áreas em que opera e operou no passado, para planejar e colocar em prática medidas que visem à contenção ou remediação do que hoje, segundo

\footnotetext{
${ }^{19}$ As informações foram fornecidas pelo Sr. Fernando Florido, Gerente de Assuntos Externos da empresa Shell Brasil Ltda, via comunicação eletrônica, no dia 14/3/2008, pelo Email: fernando.florido@shell.com.
} 
critérios mais modernos, é considerado impacto ambiental. Nada diferente disso ocorre na Vila Carioca. Área de notória atividade industrial, com diversos agentes atuando por longo período de tempo.

Desde 1992, quando estudos identificaram a presença de contaminação ambiental nas dependências da Shell na Vila Carioca, a empresa vem trabalhando com a Cetesb e outras autoridades para a definição das soluções que melhor atendam os interesses de todos os envolvidos, mais especificamente aqueles das comunidades vizinhas. Ao longo desse tempo, inúmeras ações foram tomadas pela Shell Brasil, com a participação das autoridades ambientais e de saúde, não só no sentido de se remediar o impacto de atividades passadas, mas também de fazer com que as atividades em curso estejam enquadradas nos estritos ditames regulamentares e sejam conduzidas de acordo com práticas e critérios mundialmente aceitos para atividades do tipo, incluindo o uso de equipamentos da mais alta modernidade tecnológica.

As dependências da Shell Brasil na Vila Carioca foram objeto de um dos mais completos estudos ambientais já realizados a respeito de uma área específica da cidade de São Paulo, envolvendo não só as dependências industriais em si, mas também a área de seu entorno. Existem hoje 228 poços rasos e profundos que monitoram o impacto ambiental. Até o momento, mais de 180 mil dados de solo e água subterrânea foram coletados e analisados, permitindo um acurado grau de monitoramento da situação, que vem confirmando que as medidas tomadas ou que se encontram em andamento estão corretas. Duas análises de risco foram realizadas para a base de distribuição de combustíveis do Ipiranga e áreas vizinhas, observando-se padrões nacionais e internacionais. Os dois estudos concluíram que o risco existente no local para os moradores e trabalhadores da base relacionados aos contaminantes existentes no solo e água subterrânea é insignificante. Da mesma forma, o tempo demandado para o desenvolvimento dos planos de remediação e detalhamento dos projetos de engenharia é compatível com a natureza dos trabalhos e reflete a necessidade de desenvolvimento das análises de risco acima mencionadas, que visaram a estabelecer a extensão da remediação necessária.

A Shell não tem conhecimento de que tenha havido a confirmação de casos de doenças diretamente relacionadas com as suas atividades na Base de Abastecimento Ipiranga (BIP), em Vila Carioca. Os dados apresentados em relatório preparado pelas autoridades sanitárias com base nos resultados de exames foram submetidos pela Shell Brasil a especialistas em toxicologia e saúde do trabalhador, nada tendo sido indicado que possa remotamente associar o impacto ambiental existente e as atividades da empresa a eventuais agravamentos de saúde relatados. Resultados de exames similares em outras populações não expostas às mesmas circunstâncias a que está exposta a população da Vila Carioca não diferem dos resultados obtidos com os exames desta população. 
A defesa escrita da empresa encontra-se nos autos da ACP às fls. 2.565 até 2.589. Além da peça contestatória em 31 laudas, foram apresentados documentos constitutivos da empresa, consulta e parecer da professora Ada Pellegrini Grinover ${ }^{20}$ e cópias de acórdãos.

Em preliminares a empresa Shell argüiu:

a) inépcia petição inicial por conter pedidos incertos e condicionais;

b) falta de interesse de agir, pois não há certeza de atos ilícitos ou danos;

c) Ministério Público do Estado de São Paulo é carecedor da ação na modalidade adequação, uma vez que a $\mathrm{ACP}$ não é o remédio processual apropriado para se tutelar interesses individuais, como no caso em questão;

d) ilegitimidade ativa, uma vez que se trata de direitos individuais e disponíveis.

Com referência ao mérito, argumentou:

a) a empresa não mais utiliza a área para suas atividades industriais, tendo enterrado o material no solo de sua propriedade, como era costume à época, sendo que a Cetesb recebeu comunicação deste procedimento, iniciando-se processo de monitoramento da área;

b) a Cetesb afirmou no procedimento investigatório que a Shell adotara todas as providências necessárias e que não se evidenciara risco às pessoas;

c) contratou-se uma empresa especializada em consultoria ambiental, sendo que não há danos a serem detectados. Inexistindo nexo de causalidade, não se apontando na petição inicial qualquer dano concreto, também não se pode utilizar a ação para se produzir provas;

d) nexo de causalidade ainda resta comprometido, em vista da existência de várias indústrias no local;

e) a empresa-ré vem realizando há anos o monitoramento da área, o que implica dizer que já vem restaurando o meio ambiente por vontade própria.

No despacho saneador às fls. 2.987 até 2.991, a MM. Juíza entendeu que o MP é parte ilegítima para pleitear as indenizações por danos materiais e morais tanto de trabalhadores e ex-trabalhadores da Shell e das empresas vizinhas quanto dos moradores do entorno e dos demais consumidores de água de abastecimento público e de poços em função de eventual interrupção do abastecimento e/ou do consumo de água imprópria.

Com relação a este pedido, ainda, a magistrada avaliou também que há ausência da causa de pedir, pois, nos pedidos indenizatórios descritos na petição inicial, não há descrição de fato concreto, somente suposição, e cita parte da defesa: "Não indicou, ao menos, um

\footnotetext{
${ }^{20}$ Documento em 43 laudas, refere-se à consulta sobre questões processuais discutidas nos autos da ACP movida pelo MP e outros contra a Shell, referente à contaminação no Bairro "Recanto dos Pássaros", em Paulínia/SP.
} 
doente sequer, nem mesmo uma doença concreta provocada pela ação praticada pela Shell, que o autor reputa danosa" (item 28, fls. 2.627 - da contestação da Shell).

O MP não concordou com a decisão e protocolou recurso de agravo de instrumento ${ }^{21}$ no Tribunal de Justiça do Estado de São Paulo, que concedeu parcial provimento ao recurso, para reconhecer a legitimidade do MP para tutelar os interesses transindividuais, bem como a existência da causa de pedir.

\subsubsection{Cetesb}

A defesa escrita do órgão ambiental encontra-se nos autos da ACP, às fls. 2.753 até 2.936. Além da peça contestatória, em 61 laudas, foram apresentados documentos diversos: pareceres técnicos, autos de infração, autos de inspeção, boletins de análises, relatórios de inspeção, correspondências enviadas e recebidas da Shell.

Em preliminares a Cetesb argüiu:

a) a ilegitimidade passiva da Cetesb;

b) carência de ação na modalidade adequação, uma vez que a ré vem há anos atuando em parceria com o Ministério Público para a solução do problema;

c) impossibilidade jurídica do pedido e ausência de causa de pedir, caracterizada a primeira pela não comprovação da necessidade de retirada do material tóxico do local e da responsabilidade da Cetesb pelo ato, que já vem sendo arcada pela Shell. No tocante à ausência de causa petendi, alega que não há fato autorizador da instalação da lide em relação à Cetesb e que os pedidos foram fundados em meras suposições;

d) ilegitimidade passiva da Cetesb, uma vez que não há conduta omissiva e que o dimensionamento do dano pela Shell vem sendo acompanhado pela empresa, concluindo que não colaborou de nenhuma forma para o errôneo dimensionamento do dano ambiental;

e) ilegitimidade ativa do MP para defender os interesses individuais homogêneos envolvidos no caso.

No mérito, afirma que não houve omissão da Cetesb, mas que o plano de atuação sobre o território compreende o seccionamento de toda a área, a atuação para avaliação e

\footnotetext{
${ }^{21}$ Recurso que cabe das decisões ou despachos, ou seja, dos atos pelos quais o juiz, no curso do processo, resolve questão incidente, sem encerrá-lo, conforme previsto no art. 522, do Código de Processo Civil.
} 
recuperação em etapas, fazendo crer que os pedidos da petição inicial seriam cumpridos em fase posterior, ainda não iniciada.

$\mathrm{Na}$ contestação, a Cetesb faz um histórico do monitoramento realizado na área, afirmando que não houve logro ou omissão, pois teria sempre exigido, naqueles nove últimos anos, que a Shell procedesse a correções no projeto, quando havia a incerteza da eficácia da medida adotada. Lembra, também, que nunca se ocultou em relação aos questionamentos da população e coloca em dúvida a capacidade técnica do assistente do MP.

Por sua vez, conforme mencionado anteriormente, o despacho saneador foi reformado e o MP foi reconhecido como parte legítima para defesa de interesses transindividuais, bem como a existência da causa de pedir, sendo que as outras questões envolvendo as condições da ação e interesse de agir serão apreciadas junto com o mérito da demanda. Concluiu, ainda, que a presença da Cetesb nos autos é importante para que possa aprofundar tais questões.

Para este trabalho, inicialmente, tentou-se realizar a entrevista com o presidente da Cetesb, porém, por um problema de agenda e dos seus inúmeros compromissos externos, foi indicado para representar e responder pelo órgão ambiental o engenheiro João Antonio Romano $^{22}$, então gerente responsável pela regional do Ipiranga.

$\mathrm{O}$ entrevistado descreveu um roteiro histórico pertinente ao caso e respondeu às questões conforme solicitado, nos termos que seguem:

A implantação da Base da Shell ocorreu no final da década de 1940 a início dos anos 1950 nesta região, que era um pólo industrial. O que gerou a contaminação no solo foi o fato de que, por muitos anos, desde aquela época, era comum a limpeza das borras oleosas formadas no fundo dos tanques de armazenamento de combustíveis e sua disposição direta no solo em áreas internas da empresa, sem nenhuma impermeabilização.

Esse procedimento acarretou a contaminação do solo, subsolo e águas subterrâneas em áreas internas à Base e seu entorno. Acrescenta que, na época, era comum a população abastecer-se das águas de poços artesianos, o que pode ocasionar a contaminação das pessoas.

A Cetesb tomou ciência da contaminação a partir do final 1993 e início de 1994, por meio da denúncia do Sindicato dos Trabalhadores em Bases de Distribuição de Combustíveis ao Ministério Público, ao Greenpeace e à própria Cetesb. Tratou-se de uma denúncia de saúde ocupacional dos trabalhadores, pois havia uma contaminação na área da empresa.

A partir desse fato, a Cetesb exigiu um trabalho de investigação da contaminação do solo, subsolo e águas subterrâneas em áreas internas da base onde as borras oleosas haviam

\footnotetext{
${ }^{22}$ Entrevista realizada em 13/11/2007 em São Paulo.
} 
sido enterradas. E começaram a se fazer reuniões, constando do processo judicial as cópias das Atas, desde 1994, com a Cetesb, o MP e a Shell. Outro fato importante é que este assunto de contaminação era muito novo em 1994 e a Cetesb, naquele ano ou no seguinte, fechou um convênio de Cooperação Internacional para Áreas Contaminadas com a GTZ (órgão ligado ao governo alemão). Também foi feito um projeto dentro da Cetesb para capacitar os técnicos a começarem a entender o assunto, analisar os projetos, fazer exigências etc. O engenheiro salienta que não se tinha o conhecimento técnico que se tem atualmente.

Para efeito de análise de contaminação ambiental, a Base da Shell/Vila Carioca foi divida em três áreas distintas:

- BIP-1 (Base Ipiranga de Petróleo) - área onde estão localizados os diversos tanques de armazenamento de combustíveis;

- Área Colorado - área interna à BIP-1, que faz divisa com inúmeras residências da Rua Colorado, onde funcionavam o antigo refeitório, a área administrativa, os vestiários e outras instalações;

-BIP-2 - área externa à BIP-1, localizada à Av. Presidente Wilson, denominada Shell Química, onde foram formulados os pesticidas até 1976/1977, quando esta atividade foi transferida para Paulínia.

Até o final de 2001, as ações de controle e remediação exigidas pela Cetesb concentraram-se na BIP-1, com a remoção dos solos contaminados e de tanques e tubulação enterrados.

Em abril de 2002, foi constatada contaminação no solo e águas subterrâneas da Rua Colorado (metais e "drins"). Constatada também durante a remoção de solo da Área Colorado, a presença de "drins" não foi informada pela Shell à Cetesb. Por essas duas ocorrências, foram lavradas duas penalidades de multa pela Cetesb à Shell, que sempre negou a contaminação e recorreu dos autos de infração.

Em maio de 2002 foi comprovada a contaminação em dois poços de abastecimento de água (“drins"): Condomínio Auriverde e Ind. Babylove, incorrendo em nova penalidade de multa à Shell.

Com relação aos problemas e agravos à saúde das pessoas, o entrevistado avaliou que este assunto pertence mais à Secretaria da Saúde, porém, paralelamente, a Cetesb efetuou um levantamento comunitário em 247 residências, para conhecer os hábitos da população e verificar a existência de poços rasos e profundos utilizados pela comunidade. Ao todo, foram detectados seis poços e o CVS foi informado e os lacrou. Hoje não existe mais essa via de 
exposição de contaminação, porque a água servida para a população é da Sabesp. Existe a contaminação no solo e subsolo.

A contaminação via aérea, ou seja, poluição atmosférica, era uma das reclamações da população vizinha, porém a Cetesb exigiu a mudança no sistema de abastecimento dos caminhões, o que proporcionou uma considerável melhora no ar. Não há mais a volatilização de combustível, então, o odor diminuiu bastante.

A Cetesb, alega, fazia reuniões com a comunidade local, a partir das quais foram criadas duas associações de bairro: a Reviva Vila Carioca e a SOS Vila Carioca. A Cetesb elaborou um boletim informativo (periódico) e distribuía para a população, para explicar o que estava ocorrendo e quais as medidas adotadas e aplicadas à Shell.

Questionado sobre quanto tempo a população ficou exposta aos riscos de contaminação, ele respondeu que é difícil saber, porém informou que a Sabesp implantou a rede de abastecimento em meados da década de 70 , portanto, aqueles se que utilizavam da água subterrânea entre as décadas de 50 a meados de 70 podem ter ingerido água com estes contaminantes. Assim, conclui que as pessoas ficaram expostas a estes riscos por um período de 20 anos.

Este caso gerou uma maior integração entre as Secretarias da Saúde, através do CVS, Secretaria Estadual do Meio Ambiente, Secretaria Municipal de Saúde e Meio Ambiente. Segundo informa, gerou até Portarias em conjunto para editar procedimento integrado. Por outro lado, para a imagem da Cetesb é prejudicial estar no pólo passivo de uma ACPambiental, por isso, afirma, seria de seu interesse que se julgasse mais rápido.

Por meio de várias reuniões entre as Secretarias do Estado e do município, MP, Cetesb e Shell, foram traçados os termos para formalizar um TAC, porém este nunca foi assinado. Ele atribui esta circunstância (opinião pessoal) ao fato de a Shell nunca ter admitido a contaminação, ter sempre recorrido dos autos de infração: provavelmente a empresa receia assinar o TAC como se estivesse assinando um termo de confissão.

Quanto à pergunta sobre o que justifica a demora na apuração dos fatos, o entrevistado respondeu que é difícil falar em demora, relacionando o período de 1994/95 (quando houve a denúncia) até 1999/00 (quando o assunto se tornou público), porque nesta época a Cetesb não tinha conhecimento sobre o assunto, teve que proceder a treinamento de seus técnicos, por meio do referido Convênio com o governo alemão. Observou que houve necessidade de novos procedimentos e ações para conhecer o problema. Depois deste período, quando se tinha maior integração com a população, nas reuniões, as ações que eram dirigidas à Shell tinham retorno mais rápido. 
Este caso de contaminação não é diferente dos outros. Antes da Cetesb (a partir de 1975) não havia nenhum outro órgão que fiscalizasse a questão em pauta. Num primeiro momento ela se preocupava com os efluentes líquidos, controle de poluição nos rios; depois, voltou-se para o controle do ar, da poluição atmosférica (chaminés das indústrias), e em meados da década de 90 é que começou a se preocupar com a disposição dos resíduos industriais. Até este período não havia conhecimento técnico de como tratar os resíduos, sendo comum enterrá-los no solo, sem nenhum tratamento.

\subsubsection{Centro de Vigilância Sanitária (CVS)}

O caso em estudo envolve problemas de saúde pública, e tendo em vista que o CVS foi acionado para acompanhar e orientar a população sobre o problema da contaminação e impactos à saúde, é importante obter a versão deste órgão sobre os fatos. Para tanto, realizouse uma entrevista com o Sr. Luís Sérgio Ozório Valentim ${ }^{23}$, indicado para representar e responder pela Divisão de Meio Ambiente do CVS, conforme segue:

Com referência ao problema de contaminação do terreno da Shell, da Vila Carioca, o entrevistado disse, fazendo uma análise sob diverso ângulo, que o problema está inserido no modelo de produção e consumo da sociedade, dentro de um capitalismo periférico, na região metropolitana da cidade de São Paulo, que concentrou muito desta produção brasileira ou paulista e, naturalmente, sem o devido controle da poluição ambiental inerente ao modelo de produção. Salienta que de 10 ou 20 anos para cá é que este foi iniciado, antes não havia nenhum controle ambiental efetivo. Então, a somatória desta concentração de atividades produtivas que faziam uso das mais variadas substâncias químicas perigosas à saúde - aliada a pouca ou quase nenhuma ação de fato do Estado para controle dessa situação - resultou em passivos ambientais que, hoje, segundo o cadastro de áreas contaminadas (AC) da Cetesb, são 1.822, com tendência de expansão. Logicamente, no seu entender, a cidade de São Paulo concentrou esses locais; se se fecha mais essa escala e se foca no espaço intra-urbano paulistano, vê-se que a Vila Carioca talvez seja uma das áreas que, de fato, mais abrigaram indústrias pesadas, com potencial de poluição muito grande.

Assim, salienta, a Vila Carioca está inserida num contexto maior de contaminação, problema para cuja compreensão a sociedade e o poder público só recentemente se organizaram. Lembrou da ação da Cetesb, que desde o início da década de 90 se organizou

\footnotetext{
${ }^{23}$ Entrevista realizada em 20/12/2007 em São Paulo.
} 
com o apoio da GTZ (órgão do governo alemão) para diagnosticar estas áreas, sendo São Paulo o único Estado do Brasil a fazer isso até hoje. A partir de então passa-se a compreender que o legado do processo de produção e crescimento do País era grande, em termos de passivo ambiental. E só mais recentemente, há cinco anos, a sociedade em geral começou a compreender que este não era apenas um problema ambiental, mas um problema de saúde pública, ou seja, que afetava diretamente a saúde daqueles que estavam no entorno das ACs, as quais poderiam e tinham o potencial para influenciar a saúde e as condições de saúde dessa população. Então, dentro desse contexto geral, a Vila Carioca tem um papel importante e fundamental, tanto é que vem sendo estudada por alguns pesquisadores.

O entrevistado avalia como muito importante, no caso em questão, a falta de fiscalização, ou melhor, a ausência de um modelo de estrutura de fiscalização, porque a industrialização paulista teve início em meados do século XIX (1860/70) e a partir daí só se intensificou, principalmente nas décadas de 20/30 do século passado. Nesse processo, não havia nenhum histórico e nenhum modelo de gestão ambiental para dar conta da fiscalização ambiental, tanto no Brasil quanto fora do País. Assim, afirma, olhava-se para os benefícios desse modelo produtivo e quase nada para as externalidades negativas, que eram muitas e às quais a sociedade era muito tolerante. Desta forma, não se fazia nenhuma correlação entre a fumaça que saía das chaminés, os resíduos que eram enterrados no solo ou os efluentes lançados nos rios e os agravos à sua saúde e à influência na sua qualidade de vida, ou seja, aceitava-se de alguma forma o ônus da contaminação e da poluição. De uns 20 ou 30 anos para cá é que a sociedade foi fazendo exames e compreendendo que isso não era aceitável, e hoje já não se admitem tais ocorrências.

Quando indagado sobre como e quando o CVS tomou ciência dessa contaminação, disse que a função do CVS é intervir em fatores ambientais de risco à saúde, avaliar e gerenciar esse problema, de modo a evitar que a população se exponha a determinados agentes que possam causar danos à saúde. $\mathrm{O}$ caso da Vila Carioca começou a ser analisado pelo CVS a partir de 2001, quando o assunto chegou à grande imprensa e a Cetesb informou, "de última hora, que havia uma contaminação e uma possibilidade de exposição da população em volta. E nós fomos até o local e fizemos uma avaliação inicial, ainda sem um método mais adequado, sem o conhecimento mais aprofundado e sem o histórico ou repertório para lidar com isso, e sem referencial legal (tanto estadual quanto federal)", afirma. Para ele, a atuação do órgão foi correta: 
projeções feitas, não atingiria os poços da região. Algumas análises do CVS e Cetesb mostraram que havia cinco contaminados, o caso mais grave era o do Condomínio Residencial, que estava de 203 a 300 metros da empresa Shell do Brasil, que continha tetracloretenos e drins, que era dos organoclorados produzidos pela Shell, em níveis acima do padrão de potabilidade estabelecido por normas brasileiras. Assim, interditamos o poço, ou seja, interrompemos a rota de exposição e iniciou todo um processo, (...) e a sociedade tomou consciência de que aquele não era apenas um problema ambiental, mas também de saúde pública, pois até então ela estava alheia à discussão, até verificar que estava tomando água contaminada.

Com relação aos agravos à saúde, asseverou que a população fez uma pressão muito grande e exigia que a Secretaria da Saúde desse uma resposta sobre os eventuais problemas de saúde que teria em virtude da exposição àquelas substâncias. Houve também outras declarações variadas, por exemplo, de um toxicologista, segundo o qual pessoas desta área estariam condenadas, pois esta era pior que Hiroshima e Nagasaski, "e outras insensatezes".

O fato é que não se avalia a saúde de uma população de uma hora para outra, sem ter realmente informações ambientais mais consistentes, inclusive da história do bairro e da empresa, para saber o que se fez no local ou o que se deixou de fazer. Tínhamos que avaliar a exposição presente e a exposição passada, que é o mais difícil. De certa forma, o que nós conhecíamos era o consumo de água subterrânea com níveis de tetracloretenos e drins acima do padrão aceitável, que interrompemos a rota de exposição. Havia também uma queixa generalizada a respeito do odor, por conta dos gases lançados e emitidos pelos grandes tanques, que atingiam de alguma forma a comunidade, pelo processo de enchimento dos caminhões-tanque com combustíveis, e existia a possibilidade de rota de exposição através de inalação dessas substâncias voláteis.

Assim, foram publicadas algumas Portarias, no DOE, exigindo da Shell: ( $1^{\text {a }}$ Portaria) que apresentasse dados mais consistente a respeito da real situação ambiental daquela área, uma vez que a empresa estava postergando a informação; ( $2^{\mathrm{a}}$ Portaria) que alterasse o processo e a tecnologia de enchimento dos caminhões-tanque de combustíveis, de forma que não houvesse o lançamento desses gases no ambiente (como salienta o entrevistado, "este é um problema ocupacional dos funcionários e operários que estão diretamente envolvidos com o processo e também da comunidade que estava ali próxima"); ( $3^{\mathrm{a}}$ Portaria) que a empresa deixasse de utilizar a portaria de acesso, passando por dentro do bairro, pois se entendeu a questão como um problema de qualidade de vida e de segurança. Segundo informa, foi realizado, embora tenha demorado um tempo, porque era um projeto caro para a empresa.

Foi realizado um Protocolo preliminar de avaliação de saúde daquela população, para ser executado pela Prefeitura Municipal. Antes foi realizado um cadastramento da população, com informações básicas, e partiu-se para a execução do Protocolo com entrevista inicial, 
avaliações específicas do estado de saúde, cinco coletas de sangue, análises laboratoriais (Laboratório Adolf Lutz). À Shell foi exigido que pagasse parte dessas despesas, o que estava na minuta do TAC que estava sendo negociado e que não foi assinado.

Informa que foram muitas reuniões, vários meses para se chegar a este TAC, que envolveu as Secretarias de Estado e Municipal de Saúde, Secretarias de Estado e Municipal de Meio Ambiente, a empresa Shell, as duas Associações de Moradores e o MP. A respeito do que impediu a assinatura do acordo, diz ter sabido que a promotora que estava conduzindo o caso declarou, em uma reunião do Conselho Estadual de Meio Ambiente (Consema), que considerava as propostas do TAC muito tímidas e que deveriam ser feitas mais exigências, embora não tenha explicitado a deficiências.

No que se refere à demora para apuração dos fatos, o entrevistado disse que não considera haver demora, pois é um problema que foi construído por muitas décadas:

a Shell foi para a Vila Carioca na década de 40, no século passado, foi um processo de contaminação lento e constante. Existe todo um contexto bastante complicado, basta olhar uma fotografia área da região para compreender o cenário de risco que existe naquela área. Hoje, temos pelo menos 15 empresas cadastradas como contaminadas naquele envoltório, entorno da Shell, e uma série de outras empresas antigas, com 30 e 40 ou 50 anos de existência, ainda não diagnosticadas, porém que devem ter o seu passivo ambiental, muitas utilizando substâncias com potencial de contaminação de solo e áreas subterrâneas, perigosas à saúde. E temos uma série de outros impactos, temos um Conjunto Habitacional assentado em cima de uma área contaminada, temos a favela Paraguai, que foi removida de lá, temos o Rio Tamanduateí e o Ribeirão dos Meninos totalmente degradado, com qualidade da água indicada como péssima pela Cetesb. Então, há muitos problemas sociais e ambientais decorrentes de uma ocupação errada e infeliz, e, para piorar e complicar mais a situação, numa região de várzea, sujeita a enchentes. Assim, é complexa e avaliar o risco à saúde num histórico complicado como este, onde faltam informações ambientais ou de história, nem sempre é uma coisa simples. E também avaliação de saúde de exposição crônica, que ocorre a pequenas doses em um processo lento temporal, é um procedimento que exige tempo para se avaliar.

Outro aspecto que eu coloco é a falta de tradição do Sistema Único de Saúde (SUS), não somente em São Paulo, mas em todo o País, com mecanismos legais, jurídicos e econômicos para dar conta da demanda. Recentemente, o próprio Ministério da Saúde começou a fomentar avaliações de risco em alguns casos emblemáticos no País para poder utilizar a metodologia mais apropriada para lidar com estes casos. Então, se trata de um assunto complexo, que exige realmente uma estruturação para a compreensão lenta desse processo.

De qualquer forma, acredita que o Estado tem atuado bastante neste caso, lembrando que há mais de 1.800 outras ACs no Estado, sendo metade na Região Metropolitana de São Paulo. 
A contaminação de solo muitas vezes é decorrente da forma inadequada da disposição dos resíduos, ou seja, despejar nos terrenos vizinhos, dar para o carroceiro levar, contratar um caminhão e deixar que leve para qualquer lugar, enterrar no próprio terreno, como aconteceu na Shell. Essa conduta, mesmo irresponsável, era comum nesta época; hoje, imagino que até aconteça, mas há uma preocupação e um controle maior, e um olhar da sociedade muito mais rígido para que estas práticas não aconteçam como aconteciam antes. Embora o caso da Shell - Vila Carioca tenha as suas peculiaridades, um dos aspectos que considero importantes é que ela está inserida numa área de "beira linha", numa área que as indústrias fizeram muito uso por três razões, que era o modelo "fordista" de produção: 1) porque precisavam de grandes terrenos planos, para abrigar suas vastas plantas industriais, 2) na beira de córregos, ou seja, áreas de várzea, para lançar seus efluentes diretamente nos rios; e 3) a proximidade com meios de transportes, no caso a ferrovia. Então, lá é característica disso, a cidade se concentrou em volta da área, há centenas de indústrias nessa região e problemas de passivos ambientais.

Quanto à demora para julgamento de uma ação civil pública, quando envolve questões ambientais, disse que iria dar um "palpite", porque as ações judiciais têm seus encaminhamentos próprios, suas características jurídicas, que lhe escapam, mas um dos aspectos é que "aquilo que nos afeta, afeta também os outros órgãos do Executivo, Judiciário e Legislativos, que é a falta de referências históricas, embasamento, dados e informações para lidar com estes casos e de maneiras já consolidadas de agir, eu acho que tudo isso também permeia todo o trâmite jurídico desta situação".

Indagado se esta demora acarreta prejuízo para a população, respondeu que toda demora acarreta algum prejuízo, porém entende que a população esteja assistida pela Prefeitura, em termos de saúde, ainda que de maneira inadequada - "porque imagine o SUS, com toda a sua demanda e atribuições, ainda ter que dar conta de um assunto ainda muito complexo". Então, a assistência ambulatorial tradicional não dá conta disso, pois exige um conhecimento da toxicologia muito grande. De qualquer forma houve um grande avanço, começou a se executar o Protocolo, existia até uma dificuldade para fazer com que a população acatasse os procedimentos, e assim muitas pessoas deixaram de comparecer para fazer os exames. Atualmente, está-se colocando uma unidade de Saúde específica para atender aos casos de contaminação e possível exposição a riscos à saúde, e há um Programa de Saúde da Família também voltado para estes casos.

Hoje, ele disse que não vê a possibilidade de exposição daquela população a substâncias que estão lá, mas imagina que no passado tenha havido realmente em maior intensidade, certamente pelo consumo de água, pelo contato com a terra (plantar era hábito antigo) e pela inalação daquelas substâncias ao longo dos anos. Então, ele vê mais a 
possibilidade de exposição passada, a qual têm muita dificuldade de caracterizar, do que qualquer problema ligado à questão atualmente.

\subsection{Ação Civil Pública Ambiental}

O Ministério Público do Estado de São Paulo, por meio de seu representante, o promotor de Justiça do Meio Ambiente, protocolou no dia 26 de março de 2002 a petição inicial da ação civil com pedido liminar, ao pedido juntando documentos que totalizam cerca de 2.500 páginas, contra a Shell Brasil SA e a Cetesb. A ação foi distribuída em caráter de urgência para a $10^{\mathrm{a}}$ Vara da Fazenda Pública da Comarca de São Paulo, sob o $\mathrm{n}^{\mathrm{o}}$ 053.02.008495-4 (Controle 554/2002).

O despacho inicial foi proferido em 10 de abril de 2002, às fls. 2.549, sendo que entendeu a MM. Juíza indeferir o pedido liminar. Assim, o Ministério Público interpôs recurso de Agravo de Instrumento, protocolado em 26 de abril de 2002, sob o n 271.553-5/400, perante o Tribunal de Justiça do Estado de São Paulo, que foi distribuído para a 6 a Câmara de Direito Público, cujo julgamento ocorreu em 4 de novembro de 2002. Este manteve a decisão recorrida.

\subsubsection{Dos fatos e direito que fundamentam a ACP}

O representante do Ministério Público relata na petição inicial que, em 11 de janeiro de 1993, em razão de representação formulada pela Associação Civil Greenpeace e pelo Sindicato dos Trabalhadores no Comércio de Minérios Derivados de Petróleo no Estado de São Paulo, foi instaurado o IC 001/93 para apurar notícia de que a empresa Shell Brasil SA, em razão de suas atividades, contaminara o solo do terreno por ela ocupado na Vila Carioca, Bairro Ipiranga (Terminal Ipiranga). Foi encaminhada avaliação procedida pelo IPT do Estado de São Paulo, acusando a presença de chumbo no material submetido a exame.

A Cetesb, respondendo a ofício encaminhado pela Promotoria de Justiça, afirmou que as amostras demonstravam que a área estava contaminada com chumbo. A respeito disso, propôs que a empresa Shell realizasse Estudo de Avaliação de Contaminação, baseado no roteiro básico para Apresentação de Estudos Hidrogeológicos da Cetesb. A partir desse Estudo seriam estabelecidas medidas mitigadoras e corretivas, visando à recuperação ambiental da área e seu entorno. Essa agência de controle ambiental informou, ainda, que, em 
7 de junho de 1993, notificou a empresa para apresentação em 30 dias de plano de trabalho para a realização da avaliação hidrogeológica.

A referida empresa deu conta de ter atendido à determinação da Cetesb; houve uma reunião entre as duas, na qual ajustaram a data do início do cronograma.

Em 14 de janeiro de 1994, a Cetesb, por meio da Informação Técnica nº 001/94, informou ter recebido o Mapeamento Hidrogeológico da Shell, mas que esse documento encontrava-se em estudo naquele órgão e sua análise e parecer conclusivo tomariam de 45 a 60 dias.

O representante do Ministério Público, no período de abril a novembro de 1994, ou seja, passados mais de 90 dias, enviou ofícios e efetuou telefonemas à Cetesb cobrando os resultados das análises. Na verdade, foram necessárias complementações por parte da Shell, que não atendia à sua solicitação - que seria necessário adensar a rede de poços de monitoramento, especialmente no entorno da área; seria necessária também a implementação de medidas mitigadoras corretivas e de recuperação do meio degradado que somente poderiam ser executadas após cumprimento satisfatório da primeira etapa do trabalho, o que ainda não ocorrera.

Em 20 de dezembro de 1994 foi realizada uma reunião entre a PJMA, os representantes da Cetesb, da Shell e da empresa Soil Serviços Técnicos e Consultoria S/C Ltda. (empresa responsável pelos Estudos Hidrogeoambientais). Nesse encontro foram estabelecidas ações a serem adotadas pela Shell. No entanto, a análise da Cetesb ainda não fora conclusiva, embora afirmasse que, para os parâmetros analisados, os valores encontrados estavam acima dos limites toleráveis, caracterizando um comprometimento do meio geológico local. Contudo, o relatório apresentado acusava dúvidas quanto à realidade da contaminação, pois a pluma de contaminação ainda não estava devidamente mapeada, os resíduos não estavam quantificados, inclusive nem mesmo havia certeza quanto à necessidade ou possibilidade de sua remoção.

Assim, a Cetesb, em 4 de janeiro de 1995, solicitou à Shell que executasse a avaliação hidrogeológica apropriada, com apresentação de novo cronograma de trabalho.

O MP, por várias vezes, solicitou informações à Cetesb sobre a análise da proposta de trabalho apresentada pela empresa, sendo que o Órgão Ambiental respondeu, através da Informação Técnica $n^{\circ}$ 001/95, de 17 de abril de 1995, que considerou adequado o Programa de Trabalho e Cronograma para Análise de Entorno das Cavas-Base Ipiranga que a Shell apresentara em 5 de janeiro de 1994. 
O órgão ambiental também informou que tais estudos demandavam tempo longo, e como se tratava de campo relativamente novo, no qual as metodologias estavam sendo constantemente revistas, não existia um consenso sobre o melhor procedimento a ser adotado. E concluiu que, dentro das limitações, atuaria de forma a proteger a saúde pública e o meio ambiente.

Diante dessa conclusão, embora com a constatação inicial de contaminação, a Promotoria de Justiça restringiu-se a acompanhar a ação administrativamente, pois as informações técnicas da Cetesb apontavam para uma aparente e satisfatória condução em nível administrativo.

Em 10 de agosto de 1995 houve uma reunião entre MP e representantes da Cetesb, Semco-Erm do Brasil Ltda. e Shell, sendo que esta fez uma apresentação prévia do plano relativo à avaliação hidrogeoambiental, que seria entregue até o dia 18 de agosto de 1995 para análise da Cetesb.

A Promotoria de Justiça, todavia, mais uma vez cobrou a conclusão da Cetesb, entre outubro de 1995 e fevereiro de 1996, sendo que apenas em 4 de março de 1996 foi apresentado o Parecer Técnico 027/95/EETR, relativo à Avaliação Hidrogeoambiental da Base Ipiranga, com várias observações:

- Constatou que os resíduos (borras e solos contaminados) removidos das áreas D1, D2 e D3 eram perigosos e que sua destinação apropriada era a incineração;

- Quanto aos outros resíduos que permaneciam enterrados (subáreas C e B e D1), apontou que a quantificação e caracterização deveria ser executada;

- Concluiu que a quantidade de água subterrânea da área D1 deveria ser avaliada, que a existência de outras áreas com resíduos enterrados deveria ser verificada através de prospecção adequada, que a inter-relação entre os aqüíferos locais deveria ser estudada, que a análise de compostos orgânicos voláteis no solo e nas águas subterrâneas deveria ser incluída nos próximos estudos, que a capacidade de degradação e de atenuação de poluentes no solo local deveria ser adequadamente avaliada, que a rede de monitoramento e de sondagens era suficiente para a resolução do problema e que o plano de recuperação da área degradada deveria ser conduzido, incluindo uma análise de risco a ele associado;

- Concluiu, por fim, que o cronograma de trabalho proposto poderia ser aceito, e que todos os pontos destacados deveriam ser atendidos quando do desenvolvimento do 
estudo hidrogeoambiental complementar; e, inclusive, que a Shell deveria apresentar solução de destinação final dos resíduos estocados.

Dessa forma, tendo em vista a avaliação feita pela Cetesb e as conclusões por ela emitidas, as quais indicavam a suficiência da condução administrativa do problema e a necessidade de outras medidas e ações a serem empreendidas para a completa compreensão do alcance da contaminação, a Promotoria de Justiça, com base nessas informações, seguiu o monitoramento.

No espaço de seis meses, a Promotoria realizou mais consultas à Cetesb (dezembro de 1996, fevereiro, abril e junho de 1997), sendo que apenas em 23 de julho de 1997 foi apresentado o Parecer Técnico 012/97/EETR, no qual o órgão ambiental considerou o Plano de Trabalho Investigação e Remediação baseadas em Análise de Riscos - Base Shell do Ipiranga passível de ser aceito, com algumas recomendações. Logo, a condução administrativa parecia ser suficiente para a solução do problema.

$\mathrm{Na}$ seqüência, outras consultas foram efetuadas à Cetesb (ofícios de outubro e novembro de 1997), e à Shell (7 de janeiro de 1998), que encaminhou cópia do Plano e Cronograma de Avaliação Ambiental - Base do Ipiranga. Este foi juntado aos autos, e o inquérito civil permaneceu aguardando relatório conclusivo a ser fornecido.

Quanto ao relatório conclusivo em questão, cobranças foram efetuadas (ofícios em fevereiro, março e maio de 1998) e telefonema em julho 1998; após vários pedidos de prorrogação, um último ofício foi encaminhado em 8 de janeiro de 1999, para, só então, em janeiro de 1999, apresentar o Parecer Técnico 23/98/EESO.

Dentre as conclusões lançadas nesse Parecer, é importante destacar:

a) as conclusões do estudo Levantamento do Passivo Ambiental e Análise de Risco da Base de Estocagem de Combustíveis Shell - Ipiranga - São Paulo - SP não abrange toda a área objeto de estudo, pois se limitou à área de estocagem de combustíveis e de carga e descarga de produto, que também não havia sido completamente investigada; por isso, recomendava-se complementação das investigações, ampliando a área;

b) a Shell deveria apresentar as amostragens de solo e água subterrânea citadas no relatório, indicando, no caso de investigação do solo, a profundidade da coleta de cada ponto amostrado;

c) algumas incoerências foram observadas, pois valores obtidos nas análises não tinham sido devidamente utilizados, necessitando investigações adicionais em alguns casos;

d) a Shell não havia atendido às exigências da Cetesb no que toca ao sistema de poços de monitoramento; 
e) os dados disponíveis fora da área de estudo foram considerados insuficientes, o que poderia interferir na interpretação dos resultados, decorrendo, daí, a necessidade de expansão do estudo para o entorno de interesse;

f) a Cetesb entendeu fundamental a análise para definição da qualidade das águas subterrâneas que adentravam a área da Base Ipiranga, considerando imprescindível o implante de monitoramento trimestral para análise dos parâmetros de interesse nas águas subterrâneas;

g) aventou, finalmente, que, em relação aos resíduos removidos e armazenados na área da Base Ipiranga, a remoção somente poderia ser efetuada após a destinação final ser aprovada.

O Ministério Público relata que essas informações técnicas evidenciam que a empresa nunca atendeu, na integridade, às sugestões, recomendações e exigências da Cetesb; no entanto, relata ainda, o órgão ambiental sempre se contentou com este estado de coisas, deixando transparecer a suficiência da condução em nível administrativo, situação que vertia das informações técnicas.

Continuando o monitoramento, o Ministério Público solicitou informações à Cetesb sobre o cumprimento, ou não, das exigências pela Shell (ofícios de março a abril de 1999) e, em 10 de maio de 1999, aportou na Promotoria de Justiça a informação técnica na qual se lê que a empresa havia apresentado planos de trabalho referentes ao estudo complementar para levantamento das condições ambientais da Base Ipiranga/Shell e monitoramento de águas subterrâneas, os quais seriam submetidos à análise.

Enviados outros ofícios (em junho e setembro de 1999), a Cetesb encaminhou informação técnica, em que, mais uma vez, revelaram-se insuficientes os estudos, propostas e ações desenvolvidas pela Shell.

Em razão disso, aguardou-se a complementação das informações (ofícios de dezembro de 1999 e fevereiro de 2000), e a resposta da Cetesb foi no sentido de que a documentação exigida havia sido apresentada, estando previsto o relatório final para 20 de abril de 2000.

Respondendo a novo ofício (24 de abril de 2000), a Cetesb disse que havia concedido novos prazos porque necessitava de mais dados. Informou, inclusive, que havia outra área, também da Shell, cujo relatório complementar estava em análise e, em seguida, nova informação foi encaminhada, pela qual a Cetesb confirmara outra prorrogação de prazo.

Novos ofícios foram expedidos (outubro e dezembro de 2000), e a Cetesb informou que a empresa havia cumprido o prazo estipulado, apresentando a complementação ao Plano de Trabalho de Recuperação das Áreas Contaminadas, que estava em análise. 
Após todas essas ocorrências, e estando a área da Shell aos cuidados da Agência Ambiental da Cetesb que atende no bairro do Ipiranga, a Promotoria de Justiça, em 27 de junho de 2001, expediu novo ofício à Cetesb, solicitando informações urgentes quanto à situação ambiental da área e do empreendimento, bem assim se a empresa investigada vinha cumprindo as exigências do órgão e o plano de recuperação exigível.

Além de ter oficiado, a Promotoria designou reunião de trabalho para 16 de agosto de 2001, para o que manteve contato telefônico com a Cetesb, cobrando a informação; a Shell, por seus representantes, apresentou documentação para ser anexada aos autos do procedimento.

A Cetesb, respondendo ao ofício, encaminhou nova Informação Técnica, na qual, após fazer um relato da situação, concluiu que "no que diz respeito à avaliação de contaminação da área da Base do Ipiranga (BIP I), considera-se que a Shell Brasil SA vem cumprindo as exigências técnicas e realizando os serviços de acordo com os prazos propostos e aceitos pela Cetesb".

Embora a par do teor dessa informação técnica, a Promotoria agendou nova reunião para o dia 11 de setembro de 2001, à qual estiveram presentes apenas os representantes da Shell. Por conta do não-comparecimento da Cetesb, outra reunião foi designada para o dia 25 de setembro de 2001, quando compareceram os representantes das instituições envolvidas.

Nessa última, após breve relato da condução dos trabalhos, a Cetesb, por seus representantes, deixou estabelecido que

\begin{abstract}
a Shell tem adotado todas as providências necessárias para remediação da área, que portanto estão a contento, enfatizando que não há providência adicional que mereça adoção, sendo suficientes as que estão em curso, sendo que, atualmente, não se evidencia risco às pessoas. (fls.519/520 da ACP)
\end{abstract}

Essas informações apontavam que o controle administrativo estava em curso, que a Shell estava adotando todas as providências necessárias e que a remediação da área estava em andamento, a contento, pelo que, num primeiro momento, a Promotoria de Justiça apenas determinou continuidade do monitoramento.

Ocorre, porém, que, em contato com o engenheiro Élio Lopes dos Santos, assistentetécnico do Centro de Apoio Operacional das Promotorias de Justiça do Meio Ambiente, esse profissional fez uma referência ao problema de Paulínia ${ }^{24}$. Diante disso, por medida de

\footnotetext{
${ }^{24} \mathrm{Na}$ década de 70 a empresa Shell Brasil S/A. implantou sua Unidade Industrial de formulação de defensivos agrícolas, no município de Paulínia/SP, vizinha (30 metros) a um bairro residencial denominado Recanto dos Pássaros. Entre os diversos agroquímicos formulados na sua unidade industrial, incluíam os inseticidas organoclorados entre outros: aldrin, endrin e DDT.
} 
cautela, a Promotoria decidiu por uma análise técnica do procedimento, abrangendo todas as informações, anexos, estudos e ações até então desenvolvidos.

O referido profissional, por sua vez, elaborou parecer técnico, em que algumas considerações devem ser destacadas:

a) O assistente técnico, inicialmente, salienta que "a condução do processo de gerenciamento para resolução do grave problema de poluição do solo e águas subterrâneas das diversas áreas da empresa Shell, bem como de outras fontes de poluição existentes no entorno, tiveram um prazo relativamente longo", isso porque "passaram-se nove anos sem soluções efetivas e definitivas de saneamento da área" (Parecer Técnico do MP - Fls. 565/566 da ACP - Proc. 08495/2002 -10ª Vara da Fazenda Pública da Capital).

b) Conclui, nessa linha de idéias, que "o trabalho não tem fim, ficando sempre uma recomendação para continuidade dos estudos sem apresentar uma solução de saneamento no tocante às águas subterrâneas, totalmente poluídas por diversos produtos químicos, entre os quais os temíveis organocloratos". Por conta disso, alerta que "em momento algum foi realizada uma análise de dioxinas e furanos, necessárias para uma área altamente contaminada por pesticidas organoclorados e hidrocarbonetos aromáticos" (Parecer Técnico do MP - Fls. 566 da ACP - Proc. 08495/2002 -10 a Vara da Fazenda Pública da Capital).

c) Criticando a proposta e ações de controle da Shell, bem como o controle administrativo até a elaboração do Laudo (março/2002) efetuado pela Cetesb, refere que "A proposta e ações de controle da empresa Shell limitam-se a remover focos de disposição de resíduos perigosos, deixando o decaimento dos poluentes presentes nas águas subterrâneas por conta da natureza", justificando tal proceder "com a demora de 20 anos para atingir o receptor externo" (Parecer Técnico do MP - Fls. 566 da ACP - Proc. 08495/2002 -10ª Vara da Fazenda Pública da Capital).

Enfatiza, porém, que

Essa filosofia de trabalho da Shell erroneamente vem sendo avalizada pela Cetesb, o que pode ser verificado na Ata de Reunião de 25 de setembro de 2001, onde os representantes da Shell, CSD-Geoclock e Cetesb, na presença da Promotoria de Justiça da Capital, assinam termo de comparecimento, onde informam que o processo de remediação da área está em curso. Qual processo? Por acaso, a Cetesb entende como remediação a simples retirada de resíduos do local. (Parecer Técnico do MP - Fls. 566 da ACP - Proc. 08495/2002 $10^{a}$ Vara da Fazenda Pública da Capital)

\footnotetext{
Além dessas operações a Shell sintetizava produtos Organofosforados e realizava queima e incineração de resíduos diversos entre os quais Organoclorados. Em 1994 foi constatada a contaminação do solo e das águas subterrâneas em algumas áreas internas à sua unidade industrial.
} 
d) Fazendo um paralelo da situação ambiental da Base Ipiranga - Vila Carioca com o sítio da Shell em Paulínia-SP, destaca, o assistente-técnico:

Essa filosofia de trabalho foi a mesma aplicada em outras áreas contaminadas, por exemplo, o Site da Shell localizada no Município de Paulínia, onde o que se viu foi exatamente o contrário das previsões, tendo a pluma de poluentes (DRINS) atingido rapidamente os receptores externos que tiveram suas chácaras contaminadas por poluentes organoclorados. (Parecer Técnico do MP - Fls. 566 da ACP - Proc. 08495/2002 -10 ${ }^{\text {a }}$ Vara da Fazenda Pública da Capital).

Quanto às conseqüências dessa ocorrência, revela que "As águas dos poços, utilizadas para abastecimento da população tornaram-se impróprias, nocivas e ofensivas à saúde; danosas à fauna e à flora, resultando em inconvenientes ao bem-estar público, além de prejuízos à segurança, ao uso e gozo da propriedade e das atividades normais daquela comunidade". Acrescenta, ainda: "O resultado final desse triste evento de poluição foi a compra dessas residências pela Shell e a retirada dos seus moradores, muitos dos quais doentes" (Parecer Técnico do MP - Fls. 566/567 da ACP - Proc. 08495/2002 -10ª Vara da Fazenda Pública da Capital).

Em suma, o engenheiro, assistente-técnico do Ministério Público, no laudo técnico elaborado, deixa registrado que:

I) as propostas, iniciativas e ações desenvolvidas pela Shell eram soluções parciais, não tendo resolvido o problema da contaminação;

II) a Shell detinha conhecimento e tecnologia suficiente para esse enfrentamento, não se justificando o prazo de nove anos até então transcorrido, principalmente levando-se em conta que a situação grave se mantinham;

III) a Shell tinha conhecimento dessa situação, tanto que a contaminação aqui tratada ocorreu em outros locais onde desenvolve atividades, o que impõe que deveria ter enfrentado o problema com rigor e de maneira total, mas optou por se omitir com pleno conhecimento de tal;

IV) a Cetesb falhou no trato administrativo que empreendeu, no gerenciamento administrativo do problema, pois a gravidade da situação estava e está espelhada nos laudos, informes técnicos, dados existentes, o que impunha adoção de medidas administrativas eficientes, definitivas. Inclusive, deveria ter noticiado isso em suas informações técnicas, o que não ocorreu, haja vista que sempre referendou as prorrogações de soluções preconizadas pela Shell; 
V) a Cetesb, mais que isso, afirmou, na última reunião realizada no Ministério Público, que as ações empreendidas pela Shell estavam a contento, que não havia providência adicional a ser exigida e que não havia risco às pessoas, o que contesta, pois vislumbrava extrema gravidade na situação e ausência de solução do problema;

VI) a contaminação do solo derivada das atividades da empresa Shell era grave; havia risco efetivo para os trabalhadores da empresa, para os trabalhadores de empresas vizinhas e para a população do entorno, ou seja, havia, sim, riscos à saúde e vida das pessoas.

Concluindo o relato dos fatos, verifica-se, amparado no laudo técnico apresentado, que as providências de caráter administrativo adotadas foram e são insuficientes e, dada a gravidade da situação espelhada na informação técnica, não se via outra solução senão invocar a prestação jurisdicional, para que, sob mando judicial, a situação fosse enfrentada, então, com rigor, com efetividade e de forma total e absoluta, solucionando de vez a situação gravosa que se apontava estar instalada nas dependências da área ocupada pela empresa Shell no Bairro Vila Carioca - Ipiranga, na Capital.

\subsubsection{Andamento processual da ACP}

A ACP encontra-se em fase de produção de provas (perícia, testemunhas etc.). O MM. Juízo nomeou ${ }^{25}$ o IPT para realizar a perícia, mas o valor apresentado era muito elevado e, como não havia legalmente como exigir das partes envolvidas o pagamento, a ação ainda aguarda uma definição sobre como será realizada a perícia.

O MP apresentou um Parecer Técnico com 56 folhas, realizado por uma empresa técnica, a CSD Geoclock, e o Laudo da Coordenação de Vigilância em Saúde (Covisa), mas as rés têm contestado e apresentado Parecer Técnico divergente.

Dessa forma, a ACP aguarda nova definição para a realização de perícia técnica, para posterior julgamento da ação.

\footnotetext{
${ }^{25}$ Despacho do dia 26 de maio de 2003, às fls. 2987/2991 do Processo nº 008495.
} 


\section{Considerações Finais}

(...) são direitos indisponíveis aqueles que, por sua natureza essencial ao valor e à sobrevivência humana ou ao bem da coletividade, não poderão ser objeto de renúncia, de troca ou de cessão a terceiros (Reale apud Dinamarco, 2001, p. 214).

O Estado tem o dever de proteção da saúde, que é um direito fundamental de todos, disposto no art. $5^{\circ}$ e 196 da CF, porém, na prática, essa proteção é abalada por externalidades negativas do processo produtivo industrial. A questão do passivo ambiental (que pode ser legado pela desativação de empreendimentos industriais ou por disposição errada de resíduos químicos em geral no solo) provoca não apenas a degradação desse recurso natural, mas também a poluição das águas subterrâneas. Além de causar riscos à saúde e à segurança pública, entre outros - e o que é mais grave é que tais lesões podem ter caráter irreversível ao meio ambiente saudável, à saúde pública e à própria vida.

O princípio da precaução ${ }^{26}$, entretanto, deve ser prioritariamente utilizado quando o risco de degradação do meio ambiente é considerado irreparável ou o impacto negativo ao meio ambiente é tamanho que exige a aplicação imediata das medidas necessárias à preservação. Previne-se porque não se pode saber quais as conseqüências que determinado ato ou empreendimento causarão ao meio ambiente no espaço e/ou no tempo, quais os reflexos ou conseqüências. Há incerteza científica não dirimida a respeito.

A consagração desse princípio representa a adoção de uma nova postura em relação à degradação do meio ambiente, ou seja, a precaução exige que sejam tomadas, por parte do Estado como também por parte da sociedade em geral, medidas ambientais que, num primeiro momento, impeçam o início da ocorrência de atividades potencialmente lesivas ao meio ambiente. Mas a precaução também atua, quando o dano ambiental já está concretizado, desenvolvendo ações que façam cessar esse dano ou, pelo menos, minimizar seus efeitos.

É evidente que essas medidas ou normas relativas ao meio ambiente não implicariam estagnação da economia. O que se propõe é a utilização de novas tecnologias que contribuam para a manutenção do equilíbrio ecológico sem prejuízo ao desenvolvimento, além de um maior controle dos passivos ambientais, através uma intensificação de fiscalização.

\footnotetext{
${ }^{26}$ O princípio da precaução tem seu fundamento nos incisos I e IV do art.4 ${ }^{\circ}$ da Lei de Política Nacional do Meio Ambiente (Lei 6.938/81) e no art. 225, $\S 1^{\circ}$, incisos IV e V, da CF.
} 
Por outro lado, o desenvolvimento das cidades deveria respeitar os limites da sustentabilidade, ou seja, o desenvolvimento urbano deve ocorrer com “ordenação, sem caos e destruição, sem degradação, possibilitando uma vida urbana digna para todos” (Medauar, 2002, p. 18). Solange Teles da Silva (2007, p. 8) explica que se trata de um direito coletivo da população a cidades sustentáveis, ou seja, o direito ao acesso a condições de vida urbana digna, ao meio ambiente ecologicamente equilibrado e aos equipamentos e serviços públicos.

Ademais, o Estado deve atuar contra os riscos inerentes à vida em sociedade que guardam relação com a saúde da população e tomar as medidas cabíveis para reduzir o máximo possível os riscos existentes. Não se trata de inviabilização das atividades econômicas, mas de preocupação com a natureza e a qualidade e existência de vida futura, principalmente no ambiente urbano.

Importante destacar que não existe entre nós um Código de Proteção Ambiental de aplicação nacional. Na Constituição Federal é possível identificar vários dispositivos voltados à proteção ambiental, além de haver uma legislação infraconstitucional esparsa, por tipo de assunto.

Quanto às medidas judiciais aplicáveis para garantir direitos coletivos, deve-se ressaltar a ação popular, que é um instrumento valioso, na medida em que permite a qualquer cidadão a sua interposição; porém, existem limites para a tutela ambiental, porque tal instrumento impede pedido de indenização ou condenação à obrigação de fazer ou não fazer.

A ACP e seus instrumentos auxiliares devem ser reconhecidos como um aparato eficiente de prestação jurisdicional, além de democratizar o acesso à Justiça, pois é maior o seu alcance na preservação e implementação de direitos fundamentais e interesses difusos e coletivos. Quanto à AP, a solução seria aumentar legislativamente o seu objeto, viabilizando todos os tipos de provimentos.

É certo que os interesses coletivos geralmente reclamam uma tutela urgente, que visa à sua recomposição ou remediação. Os danos a esses interesses, uma vez consumados, são de dificílima reparação.

Assim, seria um grande avanço se as investigações fossem realizadas ante a iminência de danos ambientais e não somente quando efetivamente estes já tivessem ocorrido. Tem-se observado que, em muitos casos, a simples instauração do Inquérito Civil ou procedimento bastariam para prevenir a lesão, principalmente naquelas circunstâncias em que o risco advém de condutas omissivas por parte dos responsáveis diretos, conforme declarou o representante do MP a respeito da "força" do IC, na entrevista concedida para este trabalho. Ele atentou para a Lei de Crimes Ambientais (Lei 9605/98), que possui um pressuposto: para suspender 
prosseguimento do processo criminal, o agente deve reparar o dano no âmbito do processo civil, o que dá mais eficiência à atuação.

$\mathrm{O}$ promotor considerou os maiores entraves encontrados aqueles relacionados à perícia, à falta de recursos, pois casos de contaminação geralmente envolvem grandes áreas industriais. Acredita que, para este problema ser resolvido, será necessária alteração na Lei da ACP, que prevê que o réu não está obrigado a adiantar as despesas processuais para a perícia.

O MP presta contribuição inestimável para a tutela ambiental, é o legitimado mais atuante na ACP, quem mais propõe ações em defesa dos direitos coletivos, especialmente porque possui, por meio do inquérito civil e estrutura técnica, prerrogativas e instrumentos que dão reais condições para que se proponha a ACP, devidamente instruída e apta a ser analisada pelo Poder Judiciário.

Com referência ao Caso da Vila Carioca, o representante da Cetesb salientou que há algumas décadas não se tinha o conhecimento técnico que se tem atualmente. Outro fato salientado foi o de que só em meados da década de 90 é que se começou a se preocupar com a disposição dos resíduos industriais. Até este período não havia conhecimento técnico de como tratar os resíduos, sendo comum enterrá-los no solo, sem nenhum tratamento. Esta versão foi confirmada pelo representante do CVS, que inclusive atribuiu a demora para a apuração dos fatos a essa falta de conhecimento, de dados históricos, de metodologia adequada, entre outros fatores pertinentes.

A ACP possui mecanismos hábeis a efetuar e garantir melhor prestação jurisdicional a interesses difusos. Questionam-se as conseqüências quanto ao acesso à Justiça decorrentes da Lei de ACP e sua efetividade. Machado (2004, p. 356) pontua a questão e entende que esta ação pode melhorar e restaurar os bens e interesses defendidos, porém, sua eficácia estará condicionada à propositura de ações de modo amplo e coordenado, a fim de consolidar a função transformadora e social do Poder Judiciário, em vez de operar apenas como solução imediata para os problemas ambientais. Sua efetividade está relacionada igualmente à sensibilidade dos juízes e ao dinamismo do Ministério Público e das associações.

No caso da ACP da Vila Carioca, objeto de estudo deste trabalho, todavia, devido à delonga da ação, é importante analisar, na prática, a atuação do MP na condução do caso em função de garantir proteção ao meio ambiente e ao direito à saúde.

Para sustentar todos os seus pedidos da petição inicial, o MP descreveu uma série de providências adotadas ao longo de nove anos no IC, por ele instaurado em 1993. Nesta peça torna patente a superveniência de um laudo elaborado por um seu assistente técnico que, tendo procedido a um estudo dos documentos juntados aos autos daquele procedimento, 
traçou veredicto de morosidade e de descaso das rés (Shell e Cetesb) na condução do problema.

Verifica-se, no entanto, que o MP, durante todo o tempo em que se manteve na condução do IC, limitou-se a acompanhar como espectador os atos desenvolvidos pelas rés, sem se valer em uma única oportunidade da faculdade legal de que dispunha, de requisitar exames e perícias (conforme, art. 129, incisos III, VI e VIII, da CF; Lei 8.625/93, arts. 25 IV e 26; LC 75/93, arts. $7^{\circ}$ e $8^{\circ}$ ).

Neste caso, se o MP buscava produção de provas com o IC, tendo dificuldades, poderia utilizar-se de outro procedimento ou propor uma medida cautelar para a produção antecipada de provas, ou mesmo propor uma ACP apenas com os indícios colhidos após a denúncia da contaminação, em 1993.

Por oportuno, é importante ressaltar algumas conclusões de José Carlos Baptista Puoli (2007), que apurou haver absoluta falta de controle a respeito da atuação funcional dos integrantes do Ministério Público, sendo que este descontrole é potencializado no tocante à atuação do órgão na tutela aos interesses metaindividuais. E concluiu, ainda, que o Estado deve responder pelos danos causados pelos seus agentes, conforme dispõe art. $37, \S 6^{\circ}$ da CF.

Por outro lado, a sociedade civil organizada, estruturada como terceiro setor, é peça fundamental ao acesso à justiça ambiental, pois é de fato a maior legitimada à defesa dos interesses difusos e coletivos, em razão de ser diretamente interessada, e pode atuar em busca da proteção do ambiente, sob as mais variadas formas.

Mais do que nunca, deve ser exaltada a postura daqueles que dirigem ao Judiciário forte expectativa na questão do amplo acesso a essa função estatal, em busca de efetiva e célere tutela jurisdicional, principalmente quanto ao meio ambiente. $\mathrm{O}$ avanço do processo civil - no sentido do seu distanciamento da ótica individualista tradicional, no rumo de se constituir instrumento da tutela dos interesses coletivos, difusos e individuais homogêneos vem ao encontro dos anseios da sociedade atual, que busca a preservação da qualidade ambiental e dos recursos naturais necessários às presentes e futuras gerações.

Correto o Exmo. Ministro Sydney Sanches ao chamar a atenção para o tema em questão, ao mencionar que

vê-se, pois, que, no Brasil, a proteção ao ambiente só não se tornará efetiva se os legitimados a defendê-lo não o fizerem adequadamente ou não estiverem devidamente aparelhados para isso. Ou, ainda, se o Poder Judiciário, com suas eternas deficiências de pessoal suficiente e qualificado, suas invencíveis insuficiências orçamentárias e administrativas, ou à falta de entusiasmo de seus membros e 
servidores, não puder responder, a tempo e hora, aos reclamos da sociedade brasileira (Sanches, 1994, p. 17).

Tal situação pode-se observar dentro da ACP em questão, na qual uma denúncia de contaminação de solo foi formalizada no dia 11 de janeiro de 1993, há mais de 15 anos, sendo que a ação encontra-se com mais de 3.500 páginas e em fase de colheita de provas, porém, até o momento, não foi possível realizar a perícia judicial, em virtude do alto preço desta - logo, a decisão da causa está distante de acontecer.

Por fim, a inoperância do poder público quanto a muitas demandas sociais - não somente às questões ambientais - pode alimentar significativamente a organização da sociedade civil, dando início a um processo de representação da coletividade e de visão acerca dos valores, bens e interesses difusos e coletivos. Neste movimento, certamente em função da relevância que possui, a agenda referente às questões ambientais também foi potencializada, o que acabou por exigir que o setor social possuísse instrumentos válidos e eficientes a cumprir com seus objetivos. 


\section{Bibliografia}

ACSELRAD, Henri. Justiça Ambiental: novas articulações entre meio ambiente e democracia.

Disponível

em: http//www.justiçaambiental.org.Br/projetos/clientes/noar/noar/userfiles/17/File/JanovasAr ticulações-\%20ms.pdf>.

AGUIAR, Roberto Armando Ramos. Direito do Meio Ambiente e Participação Popular. Brasília:, Ministério do Meio Ambiente e da Amazônia Legal/ Ibama, 1994.

AITH, Fernando. Curso de Direito Sanitário: a proteção do direito à saúde no Brasil. São Paulo, Quartier Latin, 2007.

MEDAUAR, Odete. “Comentários dos arts $1^{\circ}$ a $3^{\circ}$ ". In: ALMEIDA, Fernando Dias Menezes de; MEDAUAR, Odete (Coords.). Estatuto da Cidade: Lei n. 10.257, de 10.07.2001. São Paulo, Editora Revista dos Tribunais, 2002.

ALONSO JR., Hamilton. Direito Fundamental ao Meio Ambiente e Ações Coletivas. São Paulo, Editora Revista dos Tribunais, 2006.

ANTUNES, Paulo Bessa. Direito Ambiental. Rio de Janeiro, Ed. Lúmen Júris, 2002.

ARAÚJO, Joyce Maria de. Contaminação Ambiental por Resíduos Perigosos na Vila Carioca: uma interpretação da Teoria Social na abordagem da Saúde Ambiental. 2004. Tese (Doutorado) apresentada à Faculdade de Saúde Pública da Universidade de São Paulo, São Paulo.

ATLAS. Anexo A - Ordem cronológica dos Tratados e Convenções Internacionais

Multilaterais sobre o Meio Ambiente. Disponível em>

$<$ http://www.editoraatlas.com.br/Atlas/portal/ProductDetail.ctrl.aspx?product_id=8522433 $372>$.

AYALA, Patryck de Araújo. "O princípio da precaução como impedimento constitucional à produção de impactos ambientais”. In: MORATO, José Rubens. Inovações em Direito Ambiental, Florianópolis, Fundação José Arthur Boiteux, 2000.

AZEVEDO, Plauto Faraco de. Do direito ambiental: reflexões sobre seu sentido e aplicação. Revista de Direito Ambiental, São Paulo, RT, n. 19, pp. 53-66, jul. /set. 2000.

BECK, Ulrich. La Sociedad del Riesgo global. Trad. de Jorge Navarro, Daniel Jiménez, Maria Rosa Borras. Madri, Paidós, 1998.

World Risk Society. Cambridge: Polity Press, 1999; 
BENJAMIN, Antonio Herman V. Introdução ao direito ambiental brasileiro. Revista de Direito Ambiental, RT, São Paulo, n. 14, pp. 48-82, abr. /jun. 1999. A proteção do meio ambiente nos países menos desenvolvidos: o caso da América Latina. Revista de Direito Ambiental, São Paulo, RT, n. 0, pp. 83-105, 1995

BRASIL. Constituição da República Federativa do Brasil. Promulgada em 5 de outubro de 1988 e atualizada até a Emenda Constitucional no 35, de 20/12/2001. São Paulo, Saraiva, 2002.

BUCCI, Maria Paula Dallari. Direito Administrativo e Políticas Públicas. São Paulo, Saraiva, 2002.

CAPPELLI, Silvia. "O estudo de impacto ambiental na realidade brasileira". In: BENJAMIN, Antonio Herman V. Dano Ambiental: prevenção, reparação e repressão. São Paulo: RT, 1993.

Avaliação de impacto ambiental e o componente da biodiversidade. Revista de Direito Ambiental, São Paulo, RT, n. 24, pp. 64-101, out. /dez. 2001.

CARVALHO, Carlos Gomes de. Direito ambiental: perspectivas no mundo contemporâneo. Revista de Direito Ambiental, São Paulo, RT, n. 19, pp. 201-208, jul. /set. 2000.

CAVALIERI FILHO, Sérgio. Programa de Responsabilidade Civil. São Paulo: Malheiros, 2000.

CENTRO DE VIGILÂNCIA SANTÁRIA. Divisão de ações sobre o meio ambiente. Relatório de Gestão 2001-2003. Revisão 1. Secretaria de Estado da Saúde, 2004.

CETESB. Cadastro de áreas contaminadas. Disponível em: $<$ http://www.cetesb.sp.gov.br/Solo/areas_contaminadas/relacao_areas.asp>. Acessado em: $18 / 10 / 2007$.

Disponível em: <http://www.cetesb.sp.gov.br/Institucional/portugues_historico.asp>. Acessado 20/02/08.

COMISSÃO MUNDIAL SOBRE MEIO AMBIENTE E DESENVOLVIMENTO. Nosso Futuro Comum. Rio de Janeiro, Fundação Getúlio Vargas, 1991.

CUSTÓDIO, Helita Barreira. Avaliação de custos ambientais em ações jurídicas de lesão ao meio ambiente. Revista dos Tribunais v. 652, p. 16, fev./1990.

- Direito sanitário aplicado às áreas contaminadas. Fórum de Direito Urbano e Ambiental (FDUA), Belo Horizonte, Fórum, ano 1, n. 1, jan./fev. 2002.

CUNHA, Rodrigo César de Araújo. Avaliação de Risco em Áreas Contaminadas por Fontes Industriais Desativadas: estudo de caso. 1997. Tese (Doutorado) apresentada ao Instituto de Geociências da USP, São Paulo. 
DAWALIBI, Marcelo. Licença ou autorização ambiental? Revista de Direito Ambiental, São Paulo, RT, n. 17, pp. 179-187, jan. /mar. 2000.

. O poder de polícia em matéria ambiental. Revista de Direito Ambiental, São Paulo, RT, n. 14, pp. 92-102, abr. /jun. 1999.

DEMO, P. Metodologia Científica em Ciências Sociais. 2. ed. São Paulo, Atlas, 1989.

DERANI, Cristiane. Direito Ambiental Econômico. São Paulo, Ed. Max Limonad, 2001

DIAS, Elvira Gabriela Ciacco da Silva; SÁNCHEZ, Luiz Enrique. Deficiências na implementação de projetos submetidos à avaliação de impacto ambiental no Estado de São Paulo. Revista de Direito Ambiental, São Paulo, RT, n. 23, pp. 163-204, jul. /set. 2001.

DINAMARCO, Pedro da Silva. Ação Civil Pública. São Paulo, Saraiva, 2001.

FIORILlO, Celso Antonio Pacheco. Curso de Direito Ambiental Brasileiro. São Paulo, Saraiva, 2000.

FREITAS, Vladimir Passos de. Direito Administrativo e Meio Ambiente. Curitiba, Juruá, 1998.

A Constituição Federal e a Efetividade das Normas Ambientais. 2. ed. rev. São Paulo, Editora Revista dos Tribunais, 2002.

(Coord.). "Perícia multidisciplinar no Direito Ambiental". In: Direito Ambiental em Evolução. Curitiba, Ed. Juruá, 1998.

FREITAS, Carlos Machado de; BARCELlOS, Christovam; PORTO, Marcelo Firpo de Souza. "Justiça ambiental e saúde coletiva". In: ACSELRAD, Henri (Org). Conflitos Ambientais no Brasil. Rio de Janeiro, Relume-Dumará, Fundação Heinrich Böll, 2004.

FINK, Daniel Roberto. “Alternativa à ação civil pública por dano ao ambiente”. In: MILARÉ, Édis (Coord.). Ação Civil Pública - Lei 7.347/85 - 15 anos. São Paulo, Ed. RT, 2001.

FREY, Klaus. "Políticas Públicas: um debate conceitual e reflexões referentes à prática da análise de políticas públicas no Brasil”, 1997.

GRAU, Eros Roberto. A Ordem Econômica na Constituição de 1988 (Interpretação e Crítica). São Paulo, Ed. RT, 1991.

GRINOVER, Ada Pellegrini. Mandado de Segurança coletivo: legitimação e objeto. Revista de Direito Público n. 93, 1990..

GIDDENS, Anthony. Mundo em descontrole. O que a globalização está fazendo de nós. 2. ed.

Trad. Maria Luiza X. de A. Borges. Rio de Janeiro, Record, 2002.

GIL, Antonio Carlos. Como Elaborar Projetos de Pesquisa. São Paulo, Atlas, 1996.

LANGENBUCH, Juergen Richard. A Estruturação da Grande São Paulo: estudo de geografia urbana. Rio de Janeiro, IBGE, 1970. 
LEITE, Rubens Morato Leite; AYALA, Patryck de Araújo. Direito Ambiental na Sociedade de Risco. Rio de Janeiro, Forense Universitária, 2004.

MACHADO, Paulo Affonso Leme. Estudos de Direito Ambiental. São Paulo, Malheiros, 1994.

Direito Ambiental Brasileiro. São Paulo, Malheiros, 2007.

MAGLIO, Ivan Carlos. A Descentralização da Gestão Ambiental no Brasil: o papel dos órgãos estaduais e as relações com o poder local - 1990/1999. 2000. Dissertação (Mestrado) apresentada ao Departamento de Saúde Ambiental da Faculdade de Saúde Pública da Universidade de São Paulo, São Paulo.

MANCUSO, Rodolfo de Camargo. A projetada participação equânime dos co-legitimados à propositura da ação civil pública: da previsão normativa à realidade forense. Revista do Tribunais, São Paulo, no 796/11. 2002.

Interesses difusos: conceito e legitimação para agir. 5. ed. ver. Atual. São Paulo, Editora Revista dos Tribunais, 2000.

MAZZILLI, Hugo Nigro. A Defesa dos Interesses Difusos em Juízo: meio ambiente, consumidor e outros interesses difusos e coletivos. 13. ed. rev. ampl. e atual. São Paulo, Saraiva, 2001.

Notas sobre o Compromisso de Ajustamento de Conduta. Congresso Internacional de Direito Ambiental Direito, água e vida. Organizado por Antonio Herman Benjamin. São Paulo, Imprensa Oficial, 2003. 2v.

MARTINS, Heloisa Helena T. de Souza Martins. Metodologia qualitativa de pesquisa. São Paulo, Educação e Pesquisa v. 30 n. 2, maio/ago. 2004.

MILARÉ, Edis. Curadoria do Meio-Ambiente. São Paulo, Associação Paulista do Ministério Público, 1988.

. "Tutela jurídico-civil do ambiente". Revista de Direito Ambiental. São Paulo, no 0, p. 26-72, 1995.

. "A Ação Civil Pública por Dano ao Ambiente". In: Ação Civil Pública. MILARÉ, Edis (Coord.). São Paulo, Ed. RT, 2001.

. Direito do Ambiente: doutrina, jurisprudência, glossário. 5. ed. São Paulo, Ed. Revista dos Tribunais, 2000.

; BENJAMIN, Antonio Herman V. Estudo Prévio de Impacto Ambiental: teoria, prática e legislação. São Paulo, RT, 1993.

MILLER Jr., G. Tyler. Ciência Ambiental. Trad. All Tasks; revisão técnica Welington Braz Carvalho Delitti. São Paulo: Thomson Learning, 2007. 
MIRRA, Álvaro Luiz Valery. Direito ambiental: o princípio da precaução e sua aplicação judicial. Revista de Direito Ambiental. São Paulo, RT, n. 21, pp. 92-102, jan. /mar., 2001. . Impacto Ambiental: aspectos da legislação brasileira. São Paulo, Juarez de Oliveira, 2002.

Ação Civil Pública e a Reparação do Dano ao Meio Ambiente. São Paulo, Juarez de Oliveira, $2005.89 \mathrm{p}$.

MOREIRA, José Carlos Barbosa. Ação civil pública. Revista Trimestral de Direito Público. São Paulo, nº 3, pp. 187-203, 1993

MOUSINHO Patrícia. Meio Ambiente no Século 21: 21 especialistas falam da questão ambiental nas suas áreas de conhecimento. Coordenação de André Trigueiro. 4. ed. Campinas, Armazém do Ipê (Autores Associados), 2005.

MUKAI, Toshio. Direito Ambiental Sistematizado. Rio de Janeiro, Forense Universitária, 2002.

MUSETTI, Rodrigo Andreotti. Da Proteção Jurídico-Ambiental dos Recursos Hídricos. São Paulo, LED, 2001.

NERY JR., Nelson; NERY, Rosa Maria. Código de Processo Civil Comentado e Legislação Extravagante. 10. ed. São Paulo, Editora Revista dos Tribunais, 2007.

OlIVEIRA, R. M.; BRILHANTE, O. M.; MOREIRA, J. C.; MIRANDA, A. C. Contaminação por hexaclorociclohexanos em áreas urbanas da região sudeste do Brasil. Revista de Saúde Pública, 1995, n. 28, pp. 228-33.

PFEIFFER, Roberto Augusto Castellanos. A publicidade e o direito de acesso a informações no licenciamento ambiental. Revista de Direito Ambiental, São Paulo, RT, n. 8, pp. 20-34, out./dez. 1997.

PREFEITURA DE SÃO PAULO. Secretaria Municipal do Verde e do Meio Ambiente. GEO Cidade de São Paulo: panorama do meio ambiente urbano. Brasília, Pnuma, 2004.

PORTO, Marcelo Firpo de Souza. "Saúde pública e (in)justiça ambiental no Brasil" In: ACSELRAD, H.; HERCUlANO, S.; PÁDUA, J. Justiça Ambiental e Cidadania. Rio de Janeiro, Relume-Dumará, 2004, pp. 119-140.

PUOLI, José Carlos Baptista. Responsabilidade Civil do Promotor de Justiça na Tutela a Interesses Metaindividuais. 2005. Tese (Doutorado) apresentada à Faculdade de Direito, São Paulo.

PUOLI, José Carlos Baptista. Responsabilidade civil do promotor de justiça na tutela aos interesses coletivos: meio ambiente, consumidor, improbidade administrativa. São Paulo, Editora Juarez de Oliveira, 2007. 
ROCHA, Julio César de Sá. Direito da Saúde: direito sanitário na perspectiva dos interesses difusos e coletivos. São Paulo, LTr, 1999.

RODRIGUES, Marcelo Abelha. RT Informa - 20 Anos de Ação Civil Pública. São Paulo, Editora Revista dos Tribunais, ano VI, n. 37, maio/jun. 2005.

SABSAY, Daniel Alberto. La problemática ambiental y del desarrollo sostenible en el marco de la democracia participativa. Revista de Direito Ambiental, São Paulo, RT, n. 22, pp. 3849, abr. /jun. 2001.

SALLES, Carlos Alberto de Execução Judicial em Matéria Ambiental. São Paulo, RT, 1998.

SALLUM, Samanta. Área contaminada na Cidade dos Meninos continua a céu aberto. Distrito Federal, 9/10/2004. Disponível em <http://www.correioweb.com.br>.

SALVADOR, Antonio Raphael Silva. Aspectos processuais da ação civil pública. São Paulo, Oliveira Mendes, 1997

SÁNCHEZ, Luiz Enrique. Avaliação de Impacto Ambiental: situação atual e perspectivas. São Paulo, Escola Politécnica da Universidade de São Paulo, 1993.

Desengenharia: O passivo ambiental na desativação de empreendimentos industriais. São Paulo, Ed. Universidade de São Paulo, 2001.

SANCHES, Sydney. O Poder Judiciário e a tutela do meio ambiente. Revista Jurídica. Porto Alegre, v. 42, n. 204, pp. 5-19, out. 1994.

SANTOS, Celeste Leite dos. Os Crimes contra o Meio Ambiente. Responsabilidade e sanção penal. 3. ed. São Paulo, Juarez de Oliveira, 2002.

SHIMURA, Sérgio. “O papel da associação na Ação Civil Pública”. In: Processo Civil Coletivo. São Paulo, Quartier Latin, 2005.

SILVA, Ana Cláudia Tartalia. Licenciamento Ambiental de Atividades Industriais na Região Metropolitana de São Paulo: vinte e cinco anos de atuação no Estado. 2001. Dissertação (Mestrado) apresentada à Faculdade de Saúde Pública da Universidade de São Paulo, São Paulo.

SILVA, Jose Afonso da. Direito Ambiental Constitucional. São Paulo, Malheiros, 1994.

SILVA, Solange Teles da. Políticas Públicas e Estratégias de sustentabilidade urbana. Disponível em: <http://www3.esmpu.gov.br/linha-editorial/outras-publicacoes/seriegrandes-eventos-meio-

ambiente/Solange_Teles_Politicas_publicas_e_sustentabilidade.pdf $>. \quad$ Acessado em $21 / 12 / 2007$.

SIRVINSKAS, Luís Paulo. Manual de Direito Ambiental. São Paulo, Ed. Saraiva, 2002. 
SOUZA, José Carlos. Qualidade de Vida. Disponível em: <http://www.noticias.ucdb.br>.

TJSP, 8ª Câm. De Direito Público, Ap. Cív 7.313-5 Pindamonhangaba, rel. José Santana, j. 05.11.1997, v.u.

TOMMASI, Luiz Roberto; COSTA, José Maurício Teixeira Ferro. Estudo de Impacto Ambiental. São Paulo, Cetesb/Terragraph Artes e Informática S/C LTDA, 1994.

VALENTIM, Luís Sérgio Ozório. Requalificação Urbana em Área de Risco à Saúde Devido a Contaminação do Solo por Substâncias Perigosas. 2005. Dissertação (Mestrado) apresentada à Faculdade de Arquitetura e Urbanismo da USP,. São Paulo.

.. Requalificação Urbana, Contaminação do Solo e Riscos à Saúde: um caso na cidade de São Paulo. São Paulo, Annablume/Fapesp, 2007.

VEIGA, José Eli da. Desenvolvimento Sustentável: o desafio do século XXI. Rio de Janeiro, Garamond, 2005.

$$
\text { Ciência e Cultura, jun. 2005. Disponível em: }
$$
<http://cienciaecultura.bvs.br/scielo.php?pid=S0009-67252005000200002\&scri>. Acessado em 9/12/2007.

A natureza cobra a sua conta. O Estado de S. Paulo, p. A-27, 04.06.2006. 
Anexos 


\title{
TERMO DE CONSENTIMENTO LIVRE E ESCLARECIDO
}

\begin{abstract}
PESQUISA: "AS MEDIDAS JUDICIAIS APLICADAS PARA GARANTIR O DIREITO À SAÚDE : ESTUDO DE CASO EM UMA ÁREA CONTAMINADA NA CIDADE DE SÃO PAULO."
\end{abstract}

$\mathrm{Eu}$ , estou de acordo em dar entrevista à pesquisadora Ângela Aparecida Napolitano, da Pós-Graduação em Ciências Ambientais da Universidade de São Paulo (PROCAM-USP), a qual tem a finalidade de levantar dados sobre os problemas e os entraves judiciais que dificultam a solução satisfatória e célere da questão judicial, em especial no caso da Vila Carioca.

Objetivo do estudo: Avaliar a efetividade das medidas judiciais tanto para assegurar o direito à saúde, como preservar o meio ambiente e para garantir o bem-estar da população, particularmente no tocante às áreas contaminadas na cidade de São Paulo.

Procedimento: Entrevista será gravada e possui um roteiro prévio estruturado, relativo ao estudo de caso analisado. O pesquisado poderá a qualquer momento, se assim desejar, encerar entrevista.

Confidencialidade: A identidade do participante não será revelada; se assim se manifestar neste momento:

Utilização dos dados: Os dados obtidos somente serão utilizados em comunicações científicas e para fins didáticos,

Assinatura do Pesquisado

Assinatura do orientador

Prof. Dr. Nelson da Cruz Gouveia

Departamento de Medicina Preventiva

\author{
Assinatura do pesquisador \\ Ângela Ap. Napolitano
}




\section{Anexo B: ROTEIRO DE PERGUNTAS/CVS}

DATA DA ENTREVISTA:

1) Como você explica o problema de contaminação do terreno da Shell na Vila Carioca?

2) Como e quando o CVS tomou ciência da contaminação na Vila Carioca?

3) Quais foram as providências iniciais tomadas?

4) Com relação aos problemas e agravos à saúde, como estes foram tratados?

5) Na sua opinião, o que justifica a demora na apuração dos fatos?

6) Este caso de contaminação é diferente de outros casos de contaminação de solo por resíduos industriais?

7) Na sua opinião, qual o motivo da demora para julgamento de uma ação judicial que envolve uma questão ambiental ? 


\section{Anexo C - ROTEIRO DE PERGUNTAS/Cetesb}

DATA DA ENTREVISTA:

1) Como você explica o problema de contaminação do terreno da Shell na Vila Carioca?

2) Como e quando a Cetesb tomou ciência da contaminação na Vila Carioca?

3) Quais foram as providências iniciais tomadas?

4) Com relação aos problemas e agravos à saúde, como estes foram tratados?

5) Na sua opinião, o que justifica a demora na apuração dos fatos?

6) Este caso de contaminação é diferente de outros casos de contaminação de solo por resíduos industriais?

7) Como a Cetesb encara a demanda judicial? 
Anexo D: FICHA DE ANDAMENTO PROCESSUAL 